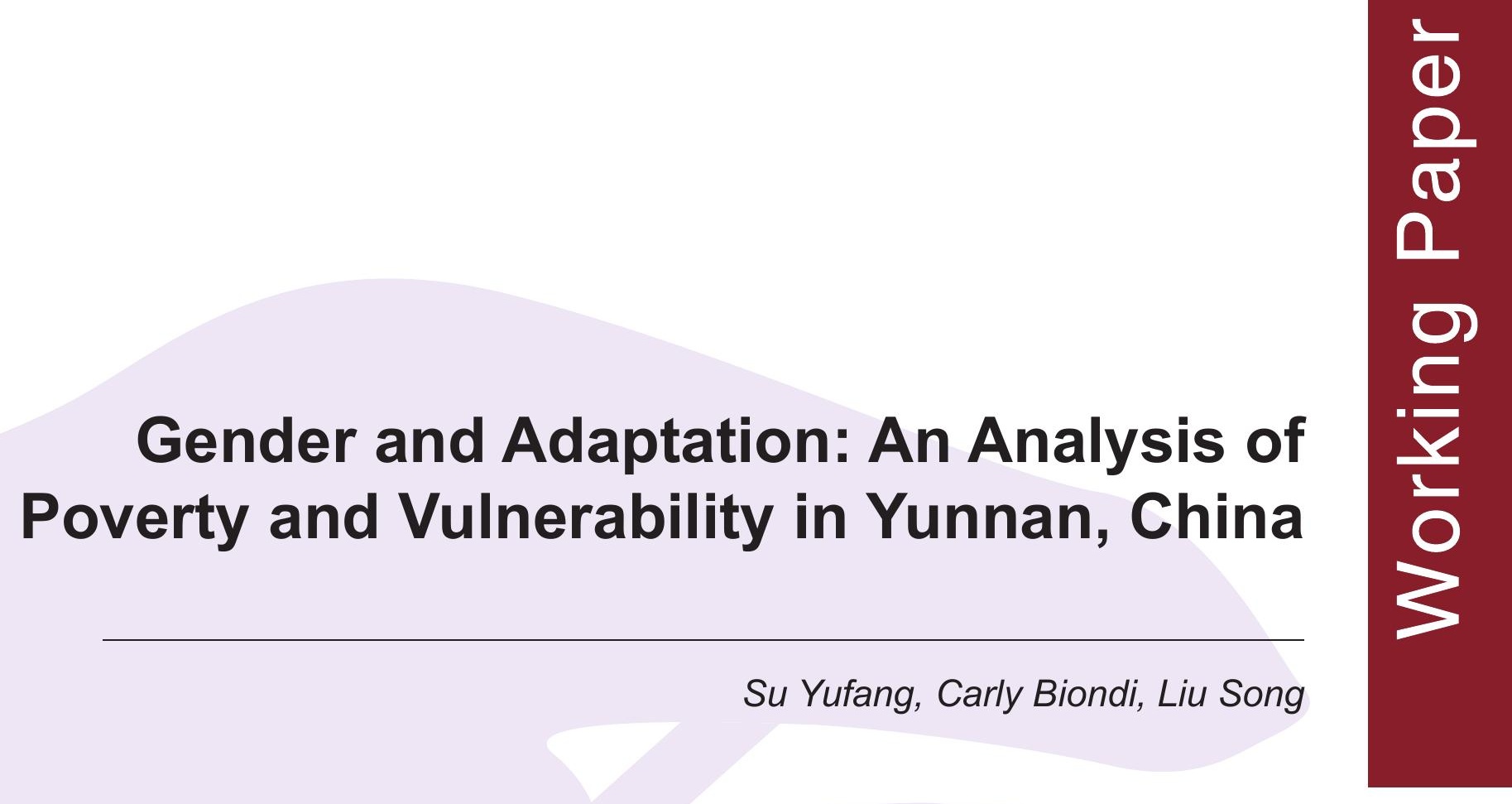




\section{Gender and Adaptation: An Analysis of Poverty and Vulnerability in Yunnan, China}

Su Yufang, Carly Biondi, Liu Song 


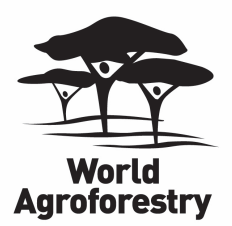

Correct citation: Su Y, Biondi C, Liu S. 2019. Gender and Adaptation: An Analysis of Poverty and Vulnerability in Yunnan, China. Working Paper 293. Kunming, China: World Agroforestry (ICRAF). DOI: http://dx.doi.org/10.5716/WP19004.PDF

Titles in the Working Paper Series aim to disseminate interim results on agroforestry research and practices and stimulate feedback from the scientific community. Other publication series from the World Agroforestry include: Agroforestry Perspectives, Technical Manuals and Occasional Papers.

Published by the World Agroforestry

Centre for Mountain Ecosystem Studies

\% Kunming Institute of Botany, Chinese Academy of Sciences

3/F North Research Building

Heilongtan, 650201 Kunming

Yunnan Province, P.R. China

Tel: +86-871-6522 3014| Fax: +86-871-6522 3377

Email: icraf-eca@cgiar.org| www.worldagroforestry.org/eca

(C) World Agroforestry 2019

Working Paper No. 293

The views expressed in this publication are those of the author(s) and not necessarily those of the World Agroforestry.

Articles appearing in this publication may be quoted or reproduced without charge, provided the source is acknowledged.

All images remain the sole property of their source and may not be used for any purpose without written permission of the source. 


\section{About the authors}

Su Yufang is an Associate Professor at Yunnan Academy of Social Sciences, and the Deputy Director of the Centre for Mountain Ecosystem Studies (CMES), a joint research centre of the Chinese Academy of Sciences and World Agroforestry (ICRAF), hosted by the Kunming Institute of Botany. She has received her PhD from Mae Fah Luang University, Thailand, and has more than twenty years of research experience in the areas of resource governance, land tenure, rural development, and local adaptation to climate change.

Carly Biondi is a project manager at the World Agroforestry (ICRAF), East and Central Asia Regional Office. She received her Master's degree in International Development from Concordia University, Irvine. Her research focuses on areas of rural development, local adaption to climate change, and participatory data collection.

Liu Song has eight years of experience in managing multiple international and national programmes, including but not limited to sustainable agriculture, freshwater conservation, ecological insurance, and valuing nature. In addition, he has great expertise at data analysis using $\mathrm{R}$ and Python. He received his master's degree at the Chinese Academy of Sciences. 


\begin{abstract}
Vulnerability assessments are crucial tools in the design of policies and interventions that target climate change. These assessments enable policymakers and researchers to formulate clear and effective responses to context-specific vulnerabilities. Climate vulnerability is a socially constructed phenomenon, and as such may be experienced differently by men and women. Using the Livelihood Vulnerability Index, we examined how gender mediates climate vulnerability in five prefectures within Yunnan Province, southwest China. Yunnan Province is a hotspot of cultural and biological diversity. Because of Yunnan's location at the base of the Tibetan Plateau, much of its population resides in high altitude rural areas, and is therefore particularly exposed to the effects of climate change. However, very little research has been conducted regarding gender and vulnerability in upland communities. Our analysis, conducted as part of the Himalayan Climate Change Adaptation Programme (HICAP), revealed gender-specific differences in consumption patterns, lifestyles, access to and control of resources, decision-making, and power relations. This complex of factors is in turn linked to an increased vulnerability to climate change. Specifically, vulnerability to climate change in female-headed households was most strongly linked to education, health, and access to water. We also found that women were largely disenfranchised from local decision-making processes; as a result, responses to climate change at the local level may fail to take their needs, priorities and skills into account. These differences highlight the need for gender mainstreaming in climate change policies and practices.
\end{abstract}

\title{
Keywords
}

Climate change, vulnerability, gender, gender-aggregated, Yunnan Province, China 


\section{Acknowledgements}

This research is part of the Himalayan Climate Change Adaptation Programme (HICAP), which is implemented jointly by the International Centre for Integrated Mountain Development (ICIMOD), GRID-Arendal and the Centre for International Climate and Environmental Research - Oslo (CICERO), in collaboration with local partners, and is funded by the governments of Norway and Sweden. It aims to contribute to enhancing the resilience of mountain communities, particularly among women, through increasing our understanding of these communities' vulnerabilities, opportunities, and potential for adaptation to change. Additional funding was provided by the 'gender cross-cutting' component of the CGIAR- Global Research Program on 'Forests, Trees, and Agroforests' (FTA). The authors thank Suman Bisht, Nand Kishor Agrawal, Iris C.P. Leikanger and Ana Maria Paez-Valenciafor their comments, and Andrew Stevenson and William Julian for comments, editing, and layout. Special thanks go to the kind-hearted local people throughout the areas who participated in our survey. We are grateful to Ms. Zhang Qian and Mr. Ren Jian who led the field survey and trained the enumerators/students who patiently conducted individual interviews. The input of all these people was essential to our survey's successful completion. 


\section{Contents}

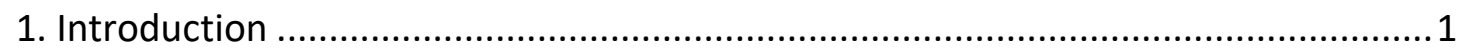

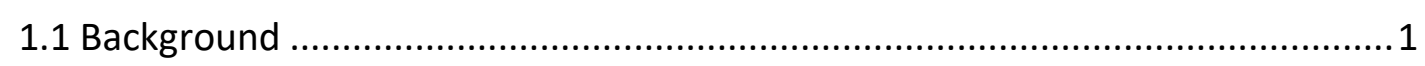

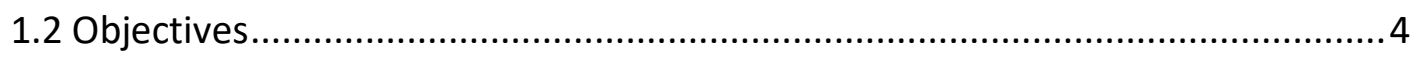

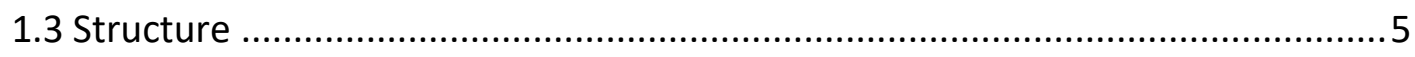

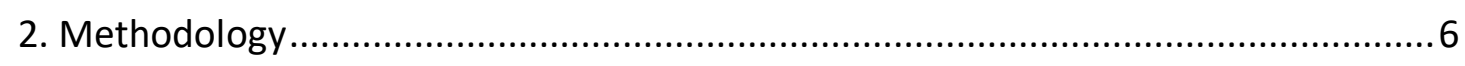

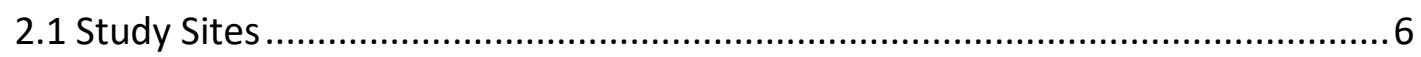

2.2 Sample Design and Coverage

2.3 Questionnaires and analytical framework ...................................................11

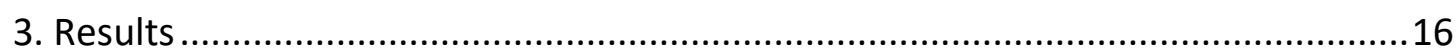

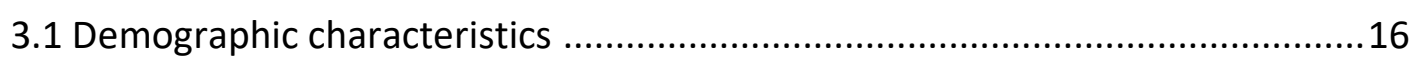

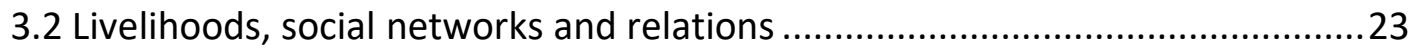

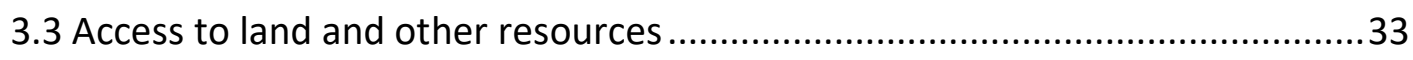

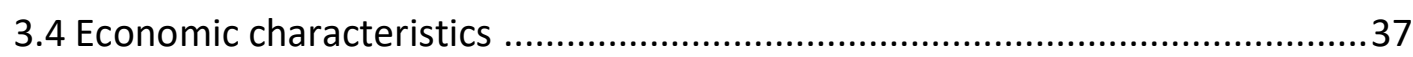

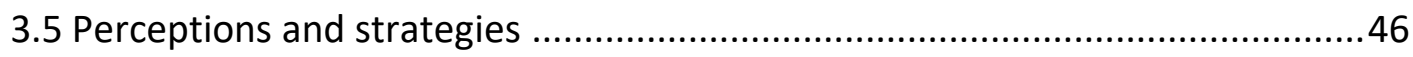

3.6 Gender disaggregated vulnerability across Prefectures ................................53

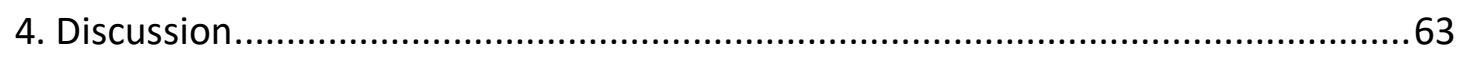

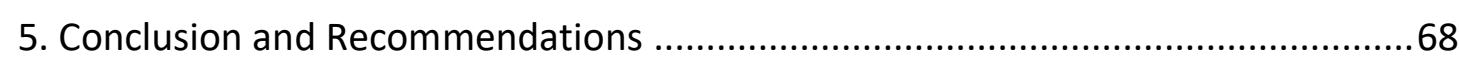

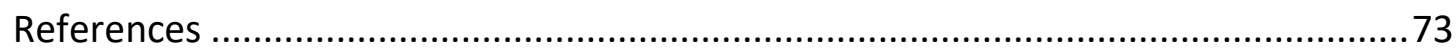




\section{List of Figures}

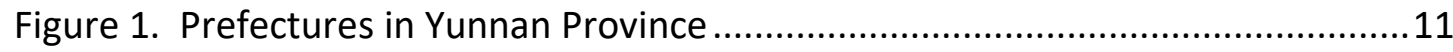

Figure 2. Gender distribution of household heads ...................................................

Figure 3. Education level of household head in years ...........................................17

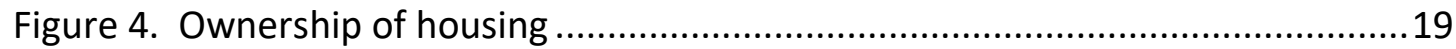

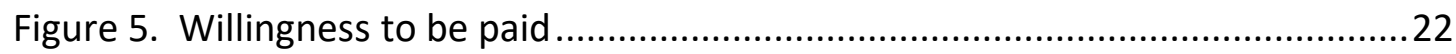

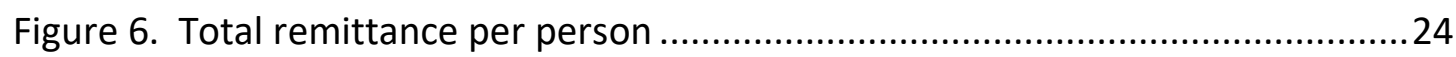

Figure 7. Sectors of employment based on individual participation in Lincang.........26

Figure 8. Sectors of employment based on individual participation in Baoshan .......27

Figure 9. Sectors of employment based on individual participation in Dali...............28

Figure 10. Sectors of employment based on individual participation in Diqing.........29

Figure 11. Sectors of employment based on individual participation in Nujiang .......30

Figure 12. Perception of influence on local level decision-making ...........................31

Figure 13. Individual participation in women's organizations..................................32

Figure 14. Share of households with year-round access to community forests .......33

Figure 15. Share of households with no access to community forests .......................34

Figure 16. Share of households with year-round access to protected areas ..............35

Figure 17. Share of households with no access to protected areas ............................35

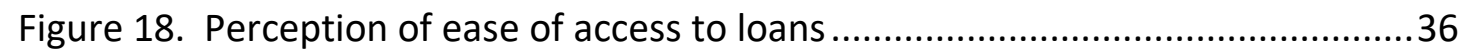

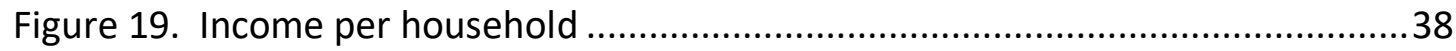

Figure 20. Perception of productivity change in staple crops in male-headed

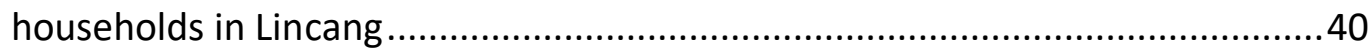

Figure 21. Perception of productivity change in staple crops in female-headed

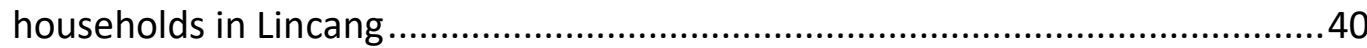

Figure 22. Perception of productivity change in staple crops in male-headed household in Baoshan

Figure 23. Perception of productivity change in staple crops in female-headed households in Baoshan

Figure 24. Perception of productivity change in male-headed households in Dali ...42

Figure 25. Perception of productivity change in staple crops in female-headed households in Dali

Figure 26. Perception of productivity change in male-headed households in Diqing 44

Figure 27. Perception of productivity change in female-headed households in Diqing

Figure 28. Perception of productivity change in staple crops of male-headed households in Nujiang.

Figure 29. Perception of productivity change in staple crops of female-headed households in Nujiang 


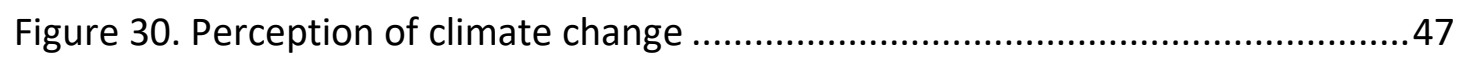

Figure 31. Livelihood vulnerability index in Lincang ...............................................56

Figure 32. Livelihood vulnerability index in Baoshan .............................................57

Figure 33. Livelihood vulnerability index in Dali ....................................................58

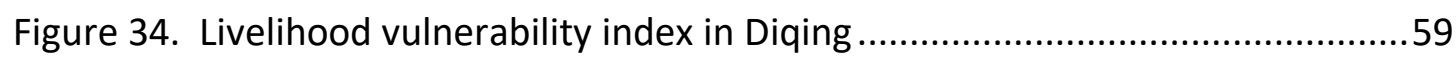

Figure 35. Livelihood vulnerability index in Nujiang ............................................60

\section{List of Tables}

Table 1 Number of Households, Population and Its Composition by Prefecture (2016)

Table 2 Land Characteristics (2016), Temperature and Precipitation (2009) by Region

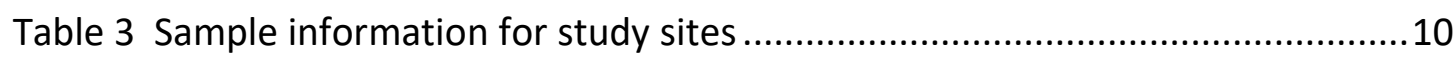

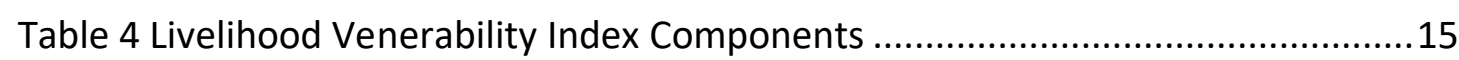

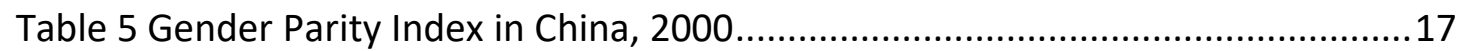

Table 6 Average number of dependents in male- and female-headed households

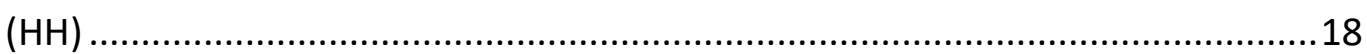

Table 7 Household size and dependency ratio ....................................................... 18

Table 8 Construction materials for exterior walls of household home .....................20

Table 9 Construction materials used for main roof of household home ...................21

Table 10 Average number of rooms per household home ......................................21

Table 11 Level of illness of respondents in survey sites ..........................................22

Table 12 Affordability of treatments for serious illness or injury ..............................23

Table 14 Decision making at county or above level .................................................31

Table 15 Membership of households in community organizations ..........................32

Table 16 Membership of households in women's organizations ...............................33

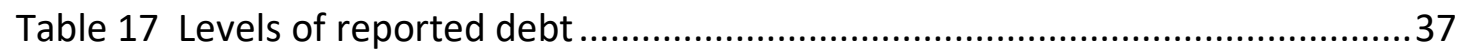

Table 18 Severity of shocks and damage in Lincang ................................................49

Table 19 Severity of shocks and damage in Baoshan ...............................................49

Table 20 Severity of shocks and damage in Dali ........................................................50

Table 21 Severity of shocks and damage in Diqing ................................................51

Table 22 Severity of shocks and damage in Nujiang..............................................51

Table 23 LVI Components of gender across five prefectures ....................................54

Table 24 Standardized LVI value of gender across five prefectures ...........................55

Table 25 LVI value of each sub-components of gender across five prefectures ........56

Table 26 LVI-IPCC value of each sub-components of gender across five prefectures 61

Table 27 LVI-IPCC index of men and women 


\section{Abbreviations}

ALDI

Agricultural livelihood diversification index

CDI Crop Diversity Index

HICAP

Himalayan Climate Change Adaptation Programme

LVI Livelihood Vulnerability Index

NTFPs

Non-timber Forest Products

PVA

Poverty and Vulnerability Analysis

SES

Socio-economic Status 


\section{Introduction}

\subsection{Background}

It is widely predicted that climate change will disproportionately affect developing countries. In 2009, the Food Policy Report produced projections for 2050 based on two of the most likely climatic scenarios (Nelson et al., 2009). Based on these projections, climate change will result in decreases in crop yields and the availability of irrigated land, especially in South Asia (Nelson et al., 2009). Reduced crop yields will force an increase in the price of staple crops, such as paddy rice, wheat, maize and soybeans, which will cause a decrease in the consumption of these products (Nelson et al., 2009). Moreover, animal feed will also become more expensive, increasing the price of meat and lowering consumption (Nelson et al., 2009). These chain reactions deriving from climate change will result in an overall decrease in available calories for the world's poor and an increase in child malnutrition by $20 \%$ (Nelson et al., 2009). The Food Policy Report also estimated that 7.1-7.3 billion USD is needed to mitigate negative impacts resulting from climate change (Nelson et al., 2009). Vulnerable groups including women, low castes, minority ethnicities, and the rural poor are often most severely affected by climate change (Nelson et al., 2009; Chen et al., 2013; Sapkota et al., 2016; van Wesenbeeck et al., 2016). The pre-existing marginalization experienced by many of these groups makes their perception and adaptation to climate change distinctive (Nelson et al., 2009). The analysis of gendered experiences can enable the use of demographic factors as indicators for common perceptions and adaptation practices.

Climate change is an increasing concern in China, one of the world's most disasterprone areas. Over the past 20 years, 300 million people have been affected by natural disasters in China (Cartier Charitable Foundation, 2014). Nine million people are annually displaced, costing 36.2 billion USD in damages (Cartier Charitable Foundation, 2014). Natural susceptibility coupled with increasingly unrestrained factors such as pollution, rapid industrialization and poorly enforced safety regulations have created ideal conditions for climate change to contribute to or cause highcasualty disasters. This trend is predicted to intensify in the future with further changes in temperature and rainfall (Ding et al., 2007; Zomer et al., 2016).

China is at the forefront of ecological vulnerability assessment regarding climate change, and Chinese scientific institutions, research centres, government planning and civil society work to incorporate climate change adaptation measures in areas of severe vulnerability, including desert, highly populated and resource-rich areas (NDRC, 2013 \& 2015). Yunnan is a rural and mountainous province with the highest 
population of ethnic minorities in China. As a result, it harbours important stores of cultural diversity and indigenous knowledge. Yunnan has some of the lowest levels of income and infrastructure in the country, but has one of the most environmentally rich landscapes. Yunnan is a recognized hotspot for biological diversity, yet these ecological resources are threatened by the impacts of climate change. These vulnerabilities have not been studied comprehensively or integrated into policy discussions in the province.

Several studies show that men and women are affected by the impacts of climate change in different ways (e.g. Paolisso et al., 2002; Omolo, 2011; Quisumbing et al., 2011). Gender-differentiated impacts of climate change are context-specific and depend on the involvement of men and women in agricultural production, socioeconomic status, location, their exposure to specific climate risks, as well as their adaptive capacity (Paolisso et al., 2002; Nelson and Stathers, 2009). Engagement in agricultural production is further related to gendered features of migration (Hunter \& David, 2011). Climate change vulnerability also depends on gendered differences in access and control over key assets (Carr, 2008; Roncoli et al., 2001), and on access to support networks, information and participation in decision-making, which are all subject to traditional gender roles (Carr, 2008). Therefore, by understanding the culturally specific gender roles present in household economies and natural resource management (Dankelman, 2002), researchers can generate insights to inform the development of targeted measures to support women in coping with longer-term changes in climate and climate variability (Nelson et al., 2002).

In order to fully understand the factors that affect gender roles in China, it is necessary to examine the historical instances of patriarchy which still manifest in the marginalization and vulnerability of women today. The widespread reverence accorded to Confucian beliefs has embedded patriarchy into every aspect of Chinese life through patriarchal, patrilineal descent, patrimony and patrilocality (Jirong, 2006). Historically, women had no social status and were dependent on men in all aspects of life. This hampered their access to property and education, limiting their access to other socio-economic dimensions (Jirong, 2006).

The establishment of the People's Republic of China in 1949 significantly altered the place of women in society (Xie, 2013). Women were given equal rights in marriage and were encouraged to pursue education and enter into the labour market (Xie, 2013). Although increases in education have been noted, significant gender segregation still exists in non-agricultural occupations. Women still only earn $70 \%$ of male wages, and mid to high level administrative and political positions are still largely held by men (Xie, 2013). 
Despite positive changes in the recent past, the overall status of 450 million Chinese women living in the countryside has not improved as rapidly as that of their urban counterparts (Pearson et al., 2002). Rural women are generally less educated and have fewer options in life (Pearson et al., 2002). Women tend to have less ownership rights, less control over productive assets, and lower education levels, all of which restrict access to opportunities for income generation and economic productivity. This leads women to have weaker bargaining positions in households and within communities. When communities and households are exposed to the impacts of climate-related events, gender biases often manifest through reductions in the resources and assets of women and female-headed households (Holmes and Jones, 2009). In times of crisis, women's entitlements to food, medical care and education are eroded more quickly than that of their male counterparts.

Concurrent with the losses women face to their social entitlements and economic assets, the burdens placed on women during times of crisis - such as reproductive labour and the collecting of firewood, water and wild food sources-are often intensified (Bryne and Baden, 1995) This is why community-level crises are particularly difficult for female-headed households to navigate (Holmes and Jones, 2009). In many cases, it takes a protracted period of time to recover from the erosion of these entitlements and assets (Holmes and Jones, 2009). In addition, emergency and statefunded relief programs are often androcentric with regard to food and water distribution, access to medical care, and refugee registration.

This focus on men as the head of the household ignores both female-headed households and the differences between men and women's emergency needs. It also erodes the important roles that women play in food production and distribution within the household (Bryne and Baden, 1995). Without specific women-centered programs, female-headed households and women will be less visible and receive fewer resources (Bryne and Baden, 1995). The combination of historical patriarchy and new capitalist economic values have significantly changed society for women. Although previously closed spheres have been opened up to urban educated women in China, it is also clear that rural women receive less opportunities and still struggle with patriarchal systems and traditional gender roles. Analysis of historical trends and the modern realities of rural women can contextualize the gendered perceptions of climate change collected in this study. Household level responses and adaptations to climate change is just one thread of a greater relationship between rural women and their environment.

Attention to the gender dimensions of climate change is relevant to the Chinese context in multiple ways. Paid labour, employment in the service and manufacturing 
sectors, and large-scale quasi-permanent migration to urban areas have been major contributors to economic growth in Yunnan (Zhang and Song, 2003). The migration of men and younger women out of rural areas has left behind many middle-aged women as the de facto heads of previously male-headed households (Mu \& van de Walle, 2011). This has led to the increasing feminization of the rural agricultural sector, with in turn has increased labour requirements placed on women, who are often already responsible for child and elderly care. This extra burden often has adverse effects on women's health and welfare (Mu \& van de Walle, 2011). Despite these changes, and despite women's active roles in driving change, there has not been any significant reevaluation of women's limited decision-making powers in household farm enterprises or community leadership structures (de Brauw et al., 2008).

This research aims to expand locally-specific knowledge on climate change and gender in order to initiate national and local partnerships, develop gender-sensitive adaptation practices, and enhance the capacity of local communities to cope with climate change in more equitable ways. Significant information gaps have been identified, especially regarding the role of gender in risk assessment and adaptation strategies of climate change. This study uses the Livelihood Vulnerability Index (LVI) in order to compare gender differences in different prefectures of Yunnan province in a holistic way.

\subsection{Objectives}

Poverty and Vulnerability Analysis (PVA) is one of the key components of the Himalayan Climate Change Adaptation Programme (HICAP) (Gerlitz et al., 2014). HICAP is one of the main initiatives undertaken by the International Centre for Integrated Mountain Development (ICIMOD), which aims to enhance the resilience of mountain communities, particularly women, through improved understanding of vulnerabilities, opportunities, and potentials for adaptation. Although PVA was intended as a general assessment of vulnerability and adaptive strategies, and was not originally designed for gender analysis, it provides gender-disaggregated data, and therefore can be adapted for this purpose. The data collected by this project focuses on comparing male and female understanding of the impacts of climate change, as well as their respective vulnerability to climatic events. The LVI analysis was completed using the PVA data from five of the most rural and ethnically diverse prefectures in Yunnan. This working paper aims to contribute to the knowledge and understanding of vulnerability and response mechanisms of communities in southwest China, with a special emphasis on the status of female-headed households in the Salween-Mekong basin. By providing detailed analysis of household-level data and resulting policy 
recommendations, we aim to influence development strategies and climate change adaption policy discourse across Yunnan.

\subsection{Structure}

This working paper consists of five chapters. The first chapter provides a brief introduction to our research, including the background and objectives of the HICAP project, as well as laying out the organization of the report. The second chapter explains the methodology used in the study, including sample design, study sites and questionnaire. The third chapter presents the results from the study based on statistical analysis, which includes demographic characteristics, social networking and relations, access to resources, local economics and climate change perceptions. Following the analysis of demographic information and access to resources, the prospects for adaptation in each location are discussed using information such as gender roles in livelihoods, cultural patterns and power in decision-making. The fourth chapter then uses the previously analysed information to discuss the intersection of gender and perceptions of climate change, as well as the different strategies explored by households to deal with shocks resulting from climate change. The fifth and final chapter contains conclusions and recommendations.

It is important to be aware that the survey is based on responses given by the participants according to their subjective perceptions. While such responses may differ between individuals, they provide a good overview at the aggregate level. Therefore, specific responses presented in the text should be contextualized and viewed accordingly. 


\section{Methodology}

\subsection{Study Sites}

Yunnan is situated in southeast China and shares a border with Myanmar, Laos, and Vietnam, along a boundary line that is 4,060 kilometers long (China Internet Information Center, 2015). In addition, Yunnan is close in proximity to Thailand, Cambodia, Bangladesh and India. Yunnan is primarily mountainous with little arable land. Yunnan regularly experiences environmental and sociological stresses, including floods, droughts, and landslides (China Internet Information Center, 2015). Yunnan Province intersects several major geographical zones, creating a unique region that is part of several trans-boundary biomes (China Internet Information Center, 2015). One of the most important biomes is the Salween-Mekong basin. The Salween-Mekong basin extends from China into the borderlands of Myanmar and Laos, before finally crossing into Cambodia and Vietnam (China Internet Information Center, 2015). This region is home to an extremely diverse range of fauna and flora. Yunnan also contains the headwaters of five major river systems: the Salween, Irrawwady, Mekong, Red, and Yangtze (China Internet Information Center, 2015).

The counties and villages of Yunnan are both poorer and more rural than the Chinese national average. Yunnan has a population of over 47.7 million, divided among 12 million households (SBYP, 2017). Around 52\% of the population is male and $48 \%$ is female, and about 55\% of the total population lives in rural areas (SBYP, 2017). Yunnan's gross regional product (GRP) per capita is only 30,949 yuan/person, which is much lower than the national average of 53,980 yuan/person. In addition, official rural net income per capita in Yunnan (9,020 yuan/person) is also lower than the national average (12,363 yuan/person) (SBYP, 2017). Yunnan's status as a middle-tier grain producer comes despite yields being lower than the national average (Hu \& Zimmer, 2013).

Yunnan also has an underdeveloped educational system, and there is a large gap in the quality of education between different prefectures. Ethnically, Yunnan is China's most diverse province, with 25 of China's 55 officially recognized minority groups present (SBYP, 2017). This study also revealed that $20 \%$ of those living in poverty are of minority descent and live in remote areas. As of the end of 2017, 5.74 million people were living below the poverty line. ${ }^{1}$

\footnotetext{
${ }^{1}$ http://special.yunnan.cn/feature15/html/2017-12/22/content 5026292.htm。
} 
Baoshan Prefecture-level City is located in western Yunnan, between the border of Myanmar and the Mekong River. The Salween River flows from north to south through the entire length of the prefecture. Baoshan has an area of $19,637 \mathrm{~km}^{2}$, of which 92\% is mountainous. There are 13 native ethnic minorities groups in Baoshan Prefecture, meaning that of Baoshan's total population, 240,000 (9.68\% of the total population) identify as an ethnic minority. The climate is mild, with average yearly temperatures between $14^{\circ} \mathrm{C}$ and $17^{\circ} \mathrm{C}$, while average yearly rainfall is $1,400 \mathrm{~mm}$. Baoshan's elevation ranges from $523 \mathrm{~m}$ to 3,780 m above sea level. Baoshan is known for agricultural production within Yunnan, and produces cash crops including tea, sugar cane, vegetables, and tobacco. Baoshan has a long history of tree-crop cultivation, primarily walnuts, pine, fruits, Sichuan pepper, camellia, and coffee. This area is also known for its mineral water and geothermal resources².

Dali Bai Autonomous Prefecture is an autonomous prefecture in northwestern Yunnan Province with an area of $29,459 \mathrm{~km}^{2}$ and has a total population of 3.56 million people by the end of 2016 (SBYP, 2017). More than $80 \%$ of the land is mountainous. The Bai ethnic minority makes up the second largest population besides Han Chinese. Dali's elevation ranges from $730 \mathrm{~m}$ to 4,295 m above sea level. There are about 160 rivers flowing through the prefecture itself, which are tributaries of the Mekong, Yangtze, Salween or Honghe basins. Cang Shan Mountain, Erhai Lake and Dali Old Town are among the most popular tourism destinations in China. While these attractions have brought millions of visitors and large income streams to the prefecture, tourism development has also triggered environmental and social challenges in Dali³.

Lincang Prefecture-level City is located in southwestern Yunnan, in the middle to lower reaches of the Mekong and Salween Rivers. It borders the Shan State of Myanmar to the southwest. Elevations within the prefecture range from $450 \mathrm{~m}$ to $3,504 \mathrm{~m}$. Han Chinese and 23 ethnic minority groups make up the total population of 2.52 million by the end of 2016 (SBYP, 2017). Lincang is the mountainous home of the Wa ethnic minority as well as home to some of the world's oldest cultivated tea trees $^{4}$.

Diqing Tibetan Autonomous Prefecture lies in northwestern Yunnan with an area of $23,870 \mathrm{~km}^{2}$. The upper Mekong and Yangtze Rivers flow through this prefecture. The highest point of Yunnan lies within Diqing Prefecture - Kawagebo Peak of Meili Snow

\footnotetext{
2 https://baike.baidu.com/item/保山/399365?fromtitle=保山市\&fromid=744251\&fr=aladdin

${ }^{3}$ https://baike.baidu.com/item/大理白族自治州

${ }^{4}$ https://baike.baidu.com/item/临沧
} 
Mountain $(6,740 \mathrm{~m})$, while Diqing's lowest point lies at 1,486 m. Due to elevation, geography and climatic factors, there are three types of ecological zones in this prefecture: high rangeland, mountain, and river valley ${ }^{5}$. The total population of Diqing prefecture is 0.41 million people, many of whom are of Tibetan ethnicity (SBYP, 2017).

Nujiang Lisu Autonomous Prefecture is located in northwestern Yunnan with an area of $14,703 \mathrm{~km}^{2}$. Nu Jiang River, known as Salween River outside China, flows through this prefecture, which borders the Tibetan Autonomous Region to the north and Myanmar to the west. Nujiang is the most ethnically diverse prefecture in China. The Derung and Nu ethnic groups are unique to Nujiang ${ }^{6}$. Nujiang is also renowned for its biodiversity, and it has a significant amount of land classified as part of the Gaoligongshan national nature reserve (The Nature Conservancy, 2016).

The demographic profiles and climatic conditions of these prefectures are shown in the following tables:

Table 1 Number of Households, Population and Its Composition by Prefecture (2016)

\begin{tabular}{|c|c|c|c|c|c|c|c|}
\hline \multirow{2}{*}{ Prefecture } & \multirow{2}{*}{$\begin{array}{l}\text { Total } \\
\text { households } \\
\text { (10,000 } \\
\text { households) }\end{array}$} & \multirow{2}{*}{$\begin{array}{l}\text { Total } \\
\text { population } \\
\text { (10,000 } \\
\text { households) }\end{array}$} & \multicolumn{2}{|c|}{$\begin{array}{l}\text { By sex } \\
(10,000 \text { persons) }\end{array}$} & \multicolumn{2}{|c|}{$\begin{array}{l}\text { By Residence } \\
\text { (10,000 persons) }\end{array}$} & \multirow{2}{*}{$\begin{array}{l}\text { Population } \\
\text { density } \\
\text { (person/sq. } \\
\text { km) }\end{array}$} \\
\hline & & & Male & Female & Urban & Rural & \\
\hline Yunnan & 1377.6 & 47770.5 & 2475.3 & 2295.2 & 2148.2 & 2622.3 & 121.0 \\
\hline Lincang & 66.3 & 252.0 & 132.2 & 119.8 & 98.2 & 153.8 & 102.9 \\
\hline Baoshan & 70.4 & 259.7 & 133.2 & 126.5 & 87.8 & 171.9 & 132.3 \\
\hline Dali & 106.9 & 356.3 & 180.6 & 175.7 & 156.9 & 199.4 & 121.0 \\
\hline Nujiang & 15.8 & 54.4 & 28.8 & 25.6 & 16.4 & 38.0 & 37.0 \\
\hline Diqing & 9.8 & 41.0 & 21.8 & 19.2 & 13.5 & 27.5 & 17.2 \\
\hline
\end{tabular}

Source: SBYP, 2017: 382.

Table 2 Land Characteristics (2016), Temperature and Precipitation (2009) by Region

\begin{tabular}{|c|c|c|c|c|}
\hline Prefecture & $\begin{array}{l}\text { Surveyed Land } \\
(10,000 \\
\text { sq. km) }\end{array}$ & $\begin{array}{l}\text { Grazing Land } \\
(10,000 \\
\mathrm{sq} \cdot \mathrm{km})\end{array}$ & $\begin{array}{l}\text { Annual Average } \\
\text { Temperature } \\
\left({ }^{\circ} \mathrm{C}\right)\end{array}$ & Precipitation $(\mathrm{mm})$ \\
\hline Yunnan & 38.32 & 14.71 & 17.4 & 835.3 \\
\hline
\end{tabular}

\footnotetext{
${ }^{5}$ https://baike.baidu.com/item/迪庆藏族自治州?fromtitle=迪庆\&fromid=6699796

${ }^{6}$ https://baike.baidu.com/item/怒江傈僳族自治州
} 


\begin{tabular}{|c|c|c|c|c|}
\hline Lincang & 2.36 & 0.20 & 19.2 & 1055.2 \\
\hline Baoshan & 1.91 & 0.15 & 16.4 & 1041.8 \\
\hline Dali & 2.83 & 0.22 & 16.5 & 679.5 \\
\hline Nujiang & 1.46 & 0.41 & 16.7 & 720.6 \\
\hline Diqing & 2.32 & 8.69 & 9.1 & 464.8 \\
\hline
\end{tabular}

Source: SBYP, 2017: 465 \& 2010: 251-254

\subsection{Sample Design and Coverage}

The PVA survey conducted in selected sites in Yunnan province was part of a largescale survey conducted in upper Indus (Pakistan), Koshi (Nepal) and eastern Brahmaputra (India) as part of the Himalayan Climate Change Adaptation Programme (HICAP). In China, the research focused on the Upper Salween-Mekong basin in Yunnan Province with all of the sample sites within it. The PVA questionnaire which was used in the other three river basins was modified in line with the local context in Yunnan. However, the survey is still comparable with those of the other river basins and comparative analysis of the results from all four basins will be produced separately. Translation of the PVA questionnaires, selection of enumerators, and finalisation of field sites within the prefectures were completed in June 2012. Instruction of the PVA trainers and enumerators took place in Kunming, and fieldtesting was conducted and completed in July 2012. Three researchers from ICIMOD and CMES travelled to Dali Prefecture for five days in August 2012 in order to gain first-hand knowledge of the possible village sites for the PVA survey. The first round of fieldwork included a questionnaire check at the end of each day as well as followup household visits that were conducted from mid-August to mid-October 2012. The interdisciplinary survey team was comprised of 2 researchers and 15 enumerators from the World Agroforestry (ICRAF), the Kunming Institute of Botany (KIB), Yunnan Agriculture University, and Yunnan Minzu University.

In order to ensure accuracy and unbiased results, 1,950 households were surveyed in 5 prefectures (390 households on average per prefecture) of Yunnan: Baoshan, Dali, Lincang, Diqing, and Nujiang (Yunnan Province has 16 prefecture-level regions ${ }^{7}, 129$

\footnotetext{
${ }^{7}$ Administrative Divisions in China

At a sub-provincial level, China is divided into three levels of vertical government administration:

- Prefectural level (州|Zhou or 市|Shi)

- County level (县| Xian or 市 | Shi)
} 
county-level entities, 1,368 township-level entities, 675 township residents' committees and 5,656 village committees). Therefore, a level of precision of $+/-5 \%$ after statistical calculation was achieved and the findings of PVA are statistically significant at the prefectural level. These prefectures were purposefully selected; however, within each prefecture, counties were randomly selected, taking into account accessibility. Villages within each random county were selected via the same method. Ultimately, the PVA survey was conducted in 45 randomly selected towns within 13 counties from the five prefectures given above.

Table 3 Sample information for study sites

\begin{tabular}{|l|l|l|l|}
\hline & Sample sites & Upper Salween-Mekong basin & Yunnan \\
\hline No. of Prefectures & 5 & 5 & 16 \\
\hline No. of Counties & 13 & 21 & 129 \\
\hline No. of townships & 45 & 232 & 1368 \\
\hline
\end{tabular}

- Township (乡|Xiang or 镇 | Zhen)

Below the township level, an elected village committee (村民委员会 | Cunmin Weiyuanhui) plays a role in organizing and handling day-to-day affairs for clusters of contiguous villages called natural villages (自 然村 | Zirancun). Natural villages are often further sub-divided into smaller communities (社 | She, or 村 民小组 | Cunmin Xiaozu). Natural villages can range from a low of 30 households to more than 100 households. Government officially extends only to a township level, which explains the considerable heterogeneity in village administration. 


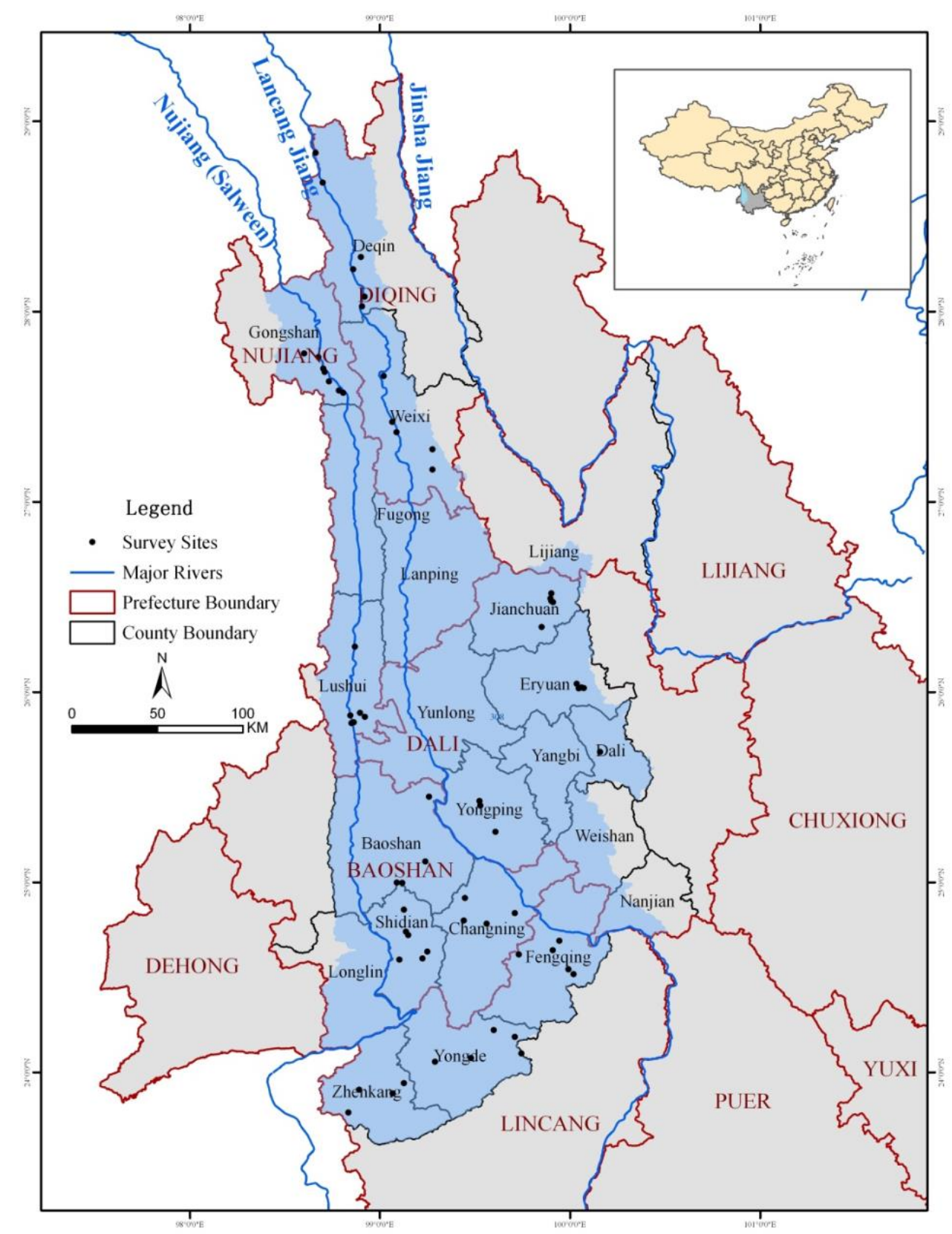

Figure 1 Prefectures in Yunnan Province

\subsection{Questionnaires and analytical framework}

In order to customize vulnerability assessment and analysis in the context of Yunnan and to accommodate the need for gender desegregated data; data collection and analysis focused on understanding women's contemporary gender roles, economic responsibility, access to resources, and general vulnerability. Throughout these analyses, male-headed households refer to households that according to the respondents were headed by men, and female-headed households refer to 
households headed by women. Although 'male' and 'female' are biological terms, we use them in these analyses to help signify a household level analysis. 'Men' and 'women' are terms used to signify respondent level analysis. The idea that gender is socially constructed in a specific society and culture should be understood as fundamental to each level of these analyses. This working paper defines the head of the household as the person who manages the economic and social responsibility for the household (Poston, Yang and Farris, 2014). The decision to identify the head of the household was left to the individual respondent.

The data collected during the PVA survey was analysed using the Livelihood Vulnerability Index (LVI), developed by Hahn et al. (2008) to measure vulnerability. Based on this index, household vulnerability can be categorized into seven groups: socio-demographic, livelihoods, social networks, health, food, water, natural disasters, and climate variability. Each component is made up of several indicators or sub-components measured on different scales. We used three sub-components to evaluate livelihoods, socio-demographics, and health, respectively; four subcomponents to evaluate social networks; two in both food and water; and lastly four sub-components to evaluate natural disasters and climate variability.

In order to analyze social demographics, four indicators were used: dependency ratio; percentage of female-headed households; percentage of household heads with no formal education; and average age of household head. To create a dependency ratio, household members under the age of 15 and over the age of 64 were combined; this group was considered dependents. Household members between the ages of 15 to 64 were combined and considered productive members of the household. The ratio thus reflects dependents to productive members in each household.

The livelihood indicator encompasses three sub-indicators: percentage of households with family members not working in their own community; percentage of households entirely dependent on agriculture as a source of income; and average agricultural livelihood diversification index (ALDI). This index refers to the types of agricultural practices, such as farming, fishing, etc., and quantifies agricultural activities on a scale between $0.20-1$. The lower the result, the better diversified the household is in its agricultural practices.

Social networks were evaluated using four indicators (Hahn et al., 2008). First, the Help Seeking Channel Index measures the ways a household can cope with an emergency. This index assigns values by evaluating the number of coping options a household has as well as the number of help-seeking channels available; the lower the value produced by the index, the better prepared a household is able to mitigate shocks. The second indicator measures the influence which the household head has on local 
governance. The third indicator measures the access that the household head has to money-lending channels. The fourth indicator measured the percentage of households that participated in different community organizations.

The health indicator consists of three sub-indicators: percentage of household health affected by natural disasters, affordability of treatments of serious illnesses or injury, and frequency of serious illness.

Access to and quality of food was measured using two indicators (Hahn et al., 2008): first, a Crop Diversity Index (CDI) refers to the number of crops planted by the household. Second, the percentage of households that do not save seeds and the percentage of households that do not save crops are also included in order to give a measure of access to food.

Understanding access to and cleanliness of water required two indicators. The first indicator consisted of the price of water compared to household income, and the second indicator measured water quality. When assessing water quality, the larger the number, the better the quality of the water.

The last indicator assesses exposure to natural disasters and climate variability, and contains three sub-indicators: percentage of households that reported changes in temperature in the past 20 years; percentage of households that reported changes in precipitation in the past 20 years; and percentage of households that reported overall environmental changes in the past 20 years. Looking at this information can indicate general climate change trends.

To understand household vulnerability and adaptive strategies under the context of climate change, the PVA survey aimed to collect accurate demographic data, climate change perception information, and to survey climate shock adaptation techniques.

The questionnaire that was used for the PVA survey had 10 major components: housing, education, household consumption, food security, water security, health and healthcare, livelihoods (including both agricultural and non-agricultural assets), access to basic facilities, accessibility, and exposure and resilience to shocks. Each component was further subdivided into subcomponents to capture information on quality, availability, and access. All components directly or indirectly provided evidence towards understanding the intersection of gender and climate change in the Upper Salween-Mekong basin. See more in Table 4. 
Table 4 Livelihood Venerability Index Components

\begin{tabular}{|c|c|c|c|}
\hline $\begin{array}{c}\text { IPCC- } \\
\text { Vulnerability }\end{array}$ & $\begin{array}{c}\text { Major } \\
\text { components }\end{array}$ & Sub-components & Explanation of sub-components \\
\hline \multirow{10}{*}{$\begin{array}{l}\text { Adaptive } \\
\text { Capacity }\end{array}$} & \multirow{3}{*}{$\begin{array}{l}\text { Socio- } \\
\text { demographic }\end{array}$} & Dependency Ratio & $\begin{array}{l}\text { Ratio of the population under } 14 \text { and } \\
\text { over } 65 \text { years of age to the } \\
\text { population between } 15 \text { and } 64\end{array}$ \\
\hline & & $\begin{array}{l}\text { Percent of households' head without } \\
\text { attending school }\end{array}$ & $\begin{array}{l}\text { Percentage of household's head } \\
\text { reports that they have not attended } \\
\text { school }\end{array}$ \\
\hline & & Average age of Household's head & Average age of Household's head \\
\hline & \multirow{3}{*}{ Livelihoods } & $\begin{array}{l}\text { Percent of households with family } \\
\text { members not working in their own } \\
\text { community }\end{array}$ & \multirow{3}{*}{$\begin{array}{l}\text { Percentage of households' adults } \\
\text { that not working in their own } \\
\text { community } \\
\text { Percentage of households that report } \\
\text { agriculture as a source of main } \\
\text { income } \\
\text { the inverse of agricultural activities } \\
\text { reported by respondent }\end{array}$} \\
\hline & & $\begin{array}{l}\text { Percent of households entirely } \\
\text { depend on agriculture as income } \\
\text { source }\end{array}$ & \\
\hline & & $\begin{array}{l}\text { Average Agricultural Livelihood } \\
\text { Diversification Index }\end{array}$ & \\
\hline & \multirow{4}{*}{$\begin{array}{l}\text { Social } \\
\text { Networks }\end{array}$} & Help Seeking Channel index & $\begin{array}{l}\text { The number of help provided by } \\
\text { various channel from } 0 \text { (none) to } 7 \\
\text { (the most) }\end{array}$ \\
\hline & & $\begin{array}{l}\text { Influence on local community's } \\
\text { regulation }\end{array}$ & $\begin{array}{l}\text { The respondents' influence on local } \\
\text { community's regulation making, } \\
\text { which is scaling from } 1 \text { (the least) to } \\
5 \text { (the most) }\end{array}$ \\
\hline & & Access to borrow money & $\begin{array}{l}\text { Accessibility to loan, which is scaled } \\
\text { from } 1 \text { (the least) to } 5 \text { (the most) }\end{array}$ \\
\hline & & $\begin{array}{l}\text { Percent of Household in different } \\
\text { organizations }\end{array}$ & $\begin{array}{l}\text { Percentage of Household in different } \\
\text { organizations }\end{array}$ \\
\hline \multirow{7}{*}{ Sensitivity } & \multirow{3}{*}{ Health } & $\begin{array}{l}\text { Percent of households' health } \\
\text { affected seriously by natural disasters }\end{array}$ & $\begin{array}{l}\text { Percentage of household report } \\
\text { serious illness }\end{array}$ \\
\hline & & $\begin{array}{l}\text { Affordability of treatment to serious } \\
\text { illness or injury }\end{array}$ & $\begin{array}{l}\text { The ability to afford medical } \\
\text { treatments to serious illness or } \\
\text { injury, which is scale from } 1 \text { (the } \\
\text { least) to } 6 \text { (the most). }\end{array}$ \\
\hline & & Frequency of serious illness & Frequency of serious illness \\
\hline & \multirow{2}{*}{ Food } & Crop Diversity Index & $\begin{array}{l}\text { The inverse of crop numbers grown } \\
\text { by a household }\end{array}$ \\
\hline & & $\begin{array}{l}\text { Percent of Household that do not } \\
\text { save seeds }\end{array}$ & $\begin{array}{l}\text { Percent of households that do not } \\
\text { save seeds from year to year }\end{array}$ \\
\hline & \multirow[t]{2}{*}{ Water } & $\begin{array}{l}\text { Affordability to purchase water } \\
\text { frequently }\end{array}$ & $\begin{array}{l}\text { Percentage of households reporting } \\
\text { water buying behaviour }\end{array}$ \\
\hline & & Water Quality & Water sources and water treatment \\
\hline \multirow[t]{3}{*}{ Exposure } & \multirow{3}{*}{$\begin{array}{l}\text { Natural } \\
\text { disasters and } \\
\text { climate } \\
\text { variability }\end{array}$} & $\begin{array}{l}\text { Percent of household report } \\
\text { temperature change in the past } 20 \\
\text { years }\end{array}$ & $\begin{array}{l}\text { Percent of household report } \\
\text { temperature change in the past } 20 \\
\text { years }\end{array}$ \\
\hline & & $\begin{array}{l}\text { Percent of household report } \\
\text { precipitation change in the past } 20 \\
\text { years }\end{array}$ & $\begin{array}{l}\text { Percent of household report } \\
\text { precipitation change in the past } 20 \\
\text { years }\end{array}$ \\
\hline & & $\begin{array}{l}\text { Percent of household report } \\
\text { environment change in the past } 20 \\
\text { years }\end{array}$ & $\begin{array}{l}\text { Percent of household report } \\
\text { environment change in the past } 20 \\
\text { years }\end{array}$ \\
\hline
\end{tabular}




\section{Results}

\subsection{Demographic characteristics}

\subsubsection{Age and sex distribution}

As previously noted, households and survey respondents were randomly selected. Gender bias was kept at the minimum in the sample selection and survey design; however, overall there were more male respondents than female respondents.

The mean age of respondents was 44 years old. Male respondents tended to be older than female respondents across all our sample sites, especially in Baoshan, where the average age of male respondents was over 47 , while that of female respondents was 42 years old. The average age of household heads in the five prefectures ranged from 41 to 48 years old. Overall, $18 \%$ of households were headed by women. The highest percentage was found in Diqing district, in which $30 \%$ of household were headed by women. Lincang had the lowest share of female-headed households (8\%). Lincang and Baoshan districts exhibited the highest proportion of male-headed households. Importantly, over $92 \%$ of women head of households were still married at the time the surveys were conducted.

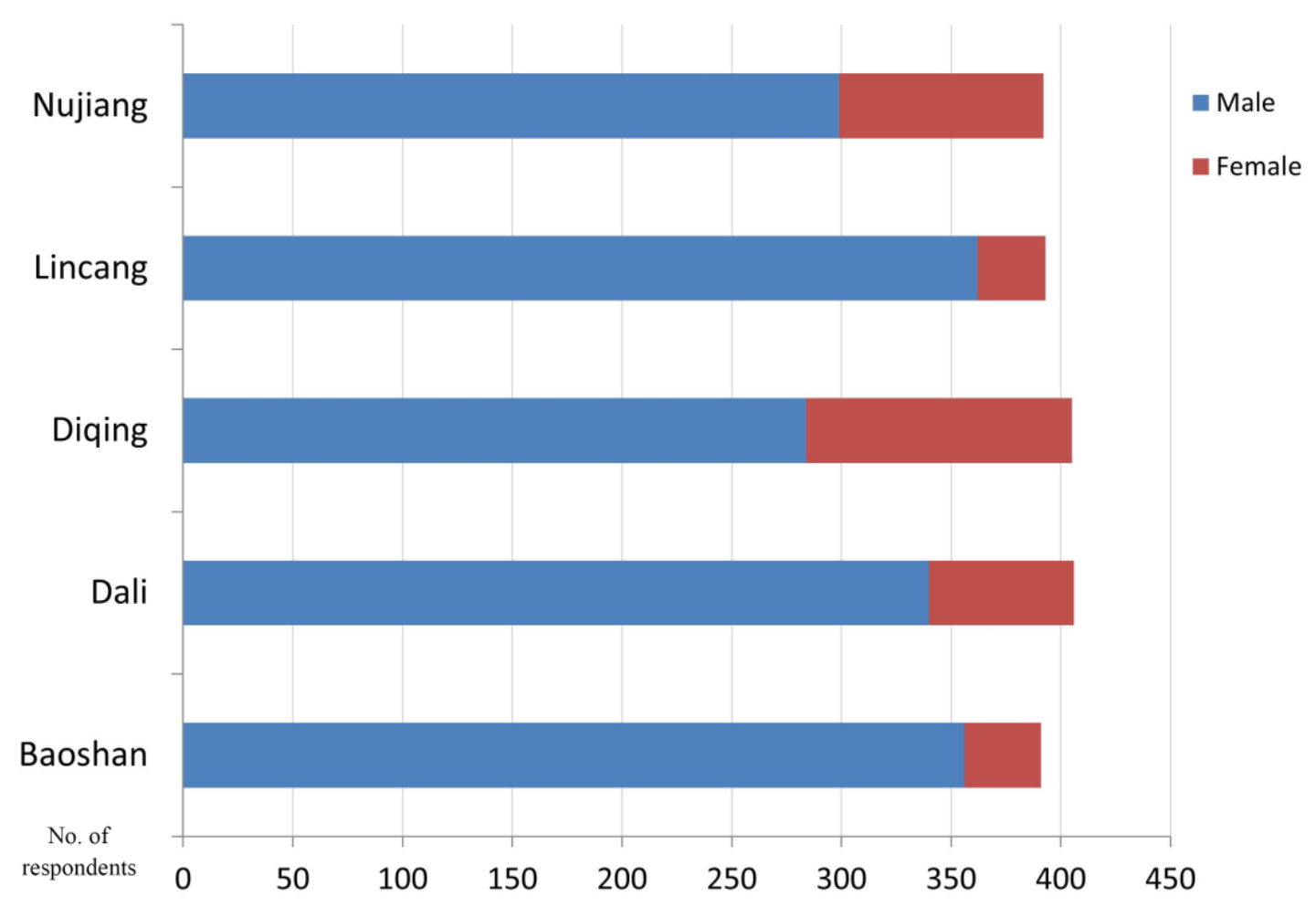

Figure 2 Gender distribution of household heads

\subsubsection{Education}

Male household heads receive more education than female household heads, measured by the average number of completed years of education. On average in Baoshan, male household heads received one additional year of education when compared to females. 
In Lincang, there was almost no difference in education. In Dali, Diqing, and Nujiang, there was less than a year's difference in education. In all districts, except Baoshan, $0.79 \%$ of male household heads had achieved professional degrees, the highest level of education among respondents. Overall, there doesn't seem to be a significant difference in the educational levels of men and women household heads.

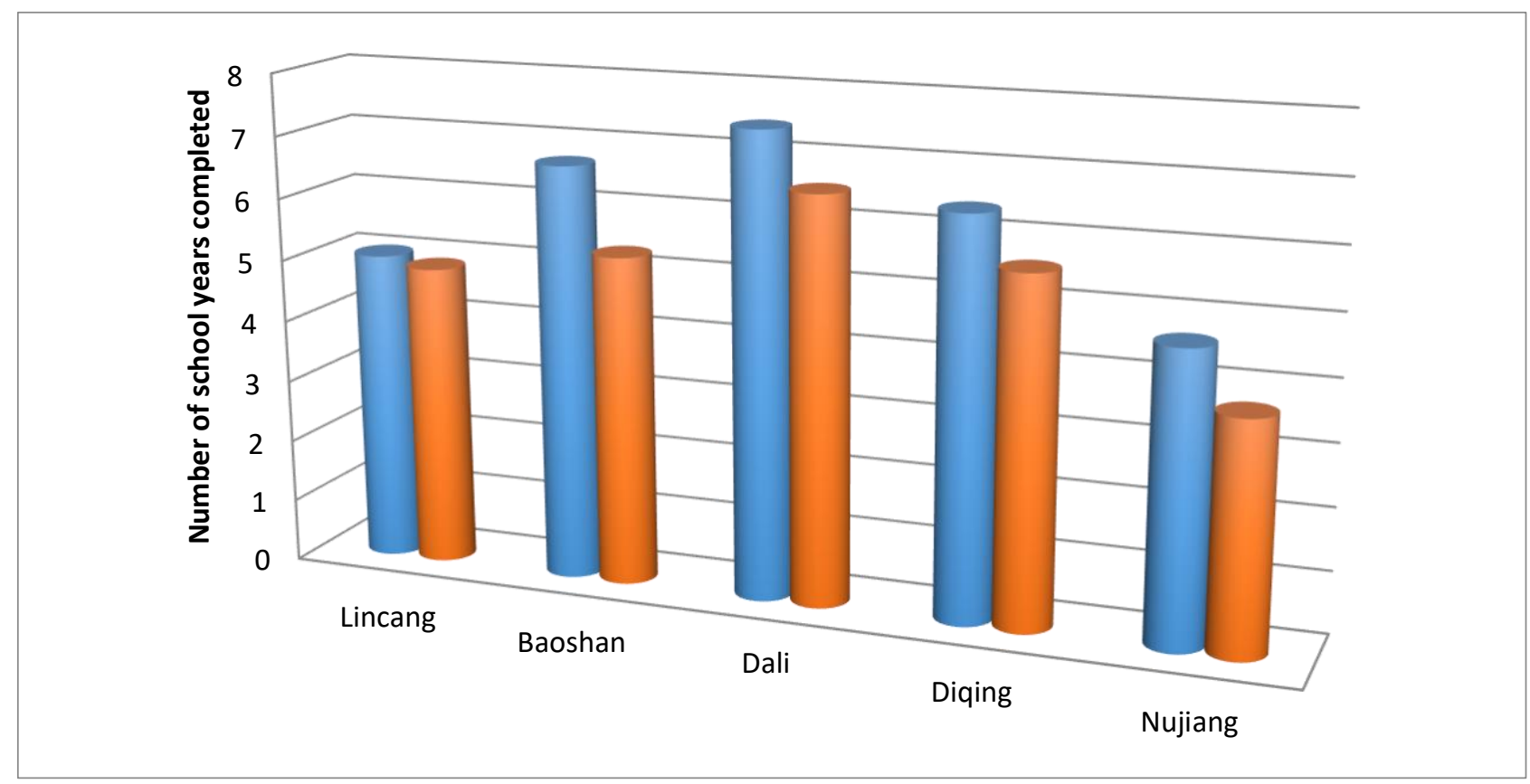

Figure 3 Education level of household head in years

According to the China Statistical Yearbook $(2014)^{8}$, the national illiteracy rates for the population older than 15 years old are $2.53 \%$ for men and $6.73 \%$ for women, respectively. But for Yunnan, the numbers are higher: $5.6 \%$ for men and $11.49 \%$ for women, respectively. Despite a reduction from $13.5 \%$ in 2000 to $6.37 \%$ in 2014 , the women's illiteracy rate in Yunnan is still much higher than that of men. See Table 5 for more information on gender disparity in China among different age groups.

Table 5 Gender Parity Index in China, $2000^{\circ}$

\begin{tabular}{|c|c|c|c|}
\hline Age Group & Sub-total & Male & Female \\
\hline Total & 9.09 & 4.86 & 13.47 \\
\hline $15-19$ & 0.92 & 0.69 & 1.17 \\
\hline $20-24$ & 1.38 & 0.92 & 1.85 \\
\hline
\end{tabular}

\footnotetext{
8 https://wenku.baidu.com/view/d703e35f647d27284b7351fa.html.

9 “The Gender Parity Index (GPI) reflects females' level of access to education compared to that of males. This is calculated for each school phase. A GPI of less than 1 indicates that there are fewer females than males in the formal education system in proportion to the appropriate school-age population. A GPI of more than 1 means that there are proportionately more girls than boys attending school. A score of 1 reflects equal enrolment rates for boys and girls" (http://www.childrencount.org.za/indicator.php?id=6\&indicator=45).
} 


\begin{tabular}{|c|c|c|c|}
\hline $25-29$ & 1.83 & 1.10 & 2.59 \\
\hline $30-34$ & 2.13 & 1.18 & 3.13 \\
\hline $35-39$ & 2.41 & 1.12 & 3.78 \\
\hline $40-44$ & 4.37 & 1.97 & 6.97 \\
\hline $45-49$ & 6.91 & 3.13 & 10.91 \\
\hline $50-54$ & 10.31 & 4.92 & 16.11 \\
\hline $55-59$ & 16.40 & 7.89 & 25.57 \\
\hline $60-64$ & 26.55 & 14.32 & 39.79 \\
\hline+65 & 48.24 & 29.00 & 65.46 \\
\hline
\end{tabular}

\subsubsection{Household size and dependency ratio}

Family size was significantly related to gender in our sample. Generally, male heads of households tended to have larger families. Geographically, households in Baoshan had the highest dependency ratios, while Nujiang had the lowest. Dali and Diqing both had relatively large household sizes at an average of four people per family.

It is also important to examine dependency in order to gain a full understanding of the economic potential of a household. If there is a high ratio between dependent and productive members of the family ("dependency ratio"), then it is assumed that the productive members face a heavier burden in providing economic support to the rest of the family.

Based on the data, male heads of households tended to have larger families, which should imply that male heads had more dependents; however, in Lincang, Baoshan, and Nujiang, male household heads had bigger families but fewer dependents. In Dali and Diqing, maleheaded households experienced a higher financial burden because the ratio between dependents and productive members is higher. In contrast, the female-headed households had more dependents, even though they had smaller household sizes. Baoshan had a lower population of working people overall, and the highest dependency ratio.

Table 6 Average number of dependents in male- and female-headed households (HH)

\begin{tabular}{llllllllllll} 
Lincang & \multicolumn{3}{c}{ Baoshan } & Dali & & Diqing & & Nujiang \\
Male & Female & Male & Female & Male & Female & Male & Female & Male & Female \\
$\mathrm{HH}$ & $\mathrm{HH}$ & $\mathrm{HH}$ & $\mathrm{HH}$ & $\mathrm{HH}$ & $\mathrm{HH}$ & $\mathrm{HH}$ & $\mathrm{HH}$ & $\mathrm{HH}$ & $\mathrm{HH}$ \\
1.318 & 1.258 & 1.553 & 1.314 & 1.509 & 1.303 & 1.257 & 1.066 & 0.956 & 0.914
\end{tabular}

Table 7 Household size and dependency ratio

\begin{tabular}{llllllllllll} 
& Lincang & & Baoshan & & Dali & & Diqing & & Nujiang \\
& $\begin{array}{l}\text { Male } \\
\mathrm{HH}\end{array}$ & $\begin{array}{l}\text { Female } \\
\mathrm{HH}\end{array}$ & $\begin{array}{l}\text { Male } \\
\mathrm{HH}\end{array}$ & $\begin{array}{l}\text { Female } \\
\mathrm{HH}\end{array}$ & $\begin{array}{l}\text { Male } \\
\mathrm{HH}\end{array}$ & $\begin{array}{l}\text { Female } \\
\mathrm{HH}\end{array}$ & $\begin{array}{l}\text { Male } \\
\mathrm{HH}\end{array}$ & $\begin{array}{l}\text { Female } \\
\mathrm{HH}\end{array}$ & $\begin{array}{l}\text { Male } \\
\mathrm{HH}\end{array}$ & $\begin{array}{l}\text { Female } \\
\mathrm{HH}\end{array}$ \\
$\begin{array}{l}\text { Household } \\
\text { Size }\end{array}$ & $4 \pm 1.67$ & $3.58 \pm 1.87$ & $3.87 \pm 1.51$ & $3.57 \pm 1.46$ & $4.29 \pm 1.57$ & $3.81 \pm 1.58$ & $4.1 \pm 1.51$ & $3.78 \pm 1.66$ & $3.59 \pm 1.41$ & $3.24 \pm 1.46$ \\
$\begin{array}{l}\text { Dependency } \\
\text { Ratio }\end{array}$ & 0.298 & 0.369 & 0.398 & 0.416 & 0.341 & 0.269 & 0.305 & 0.274 & 0.192 & 0.225 \\
$\begin{array}{l}\text { Average } \\
\text { Age }\end{array}$ & 45.07 & 43.1 & 47.68 & 42.16 & 47.34 & 43.51 & 43.83 & 43.52 & 43.47 & 40.69 \\
\hline
\end{tabular}




\subsubsection{Housing}

The types of housing and construction materials used by different households are often influenced by several demographic factors such as socio-economic status, gender and education level. The construction materials used for housing were surveyed in order to contextualize annual income and record regional preferences for construction materials. This information could be valuable in the future to better prepare housing to withstand climate shocks.

Ownership

Men and women typically legally and culturally shared ownership of housing, with the exception of Baoshan and Lincang, where men were more likely to own houses. No correlation between ownership of household and ethnicity was found in our study.

\section{Ownership of dwellings}

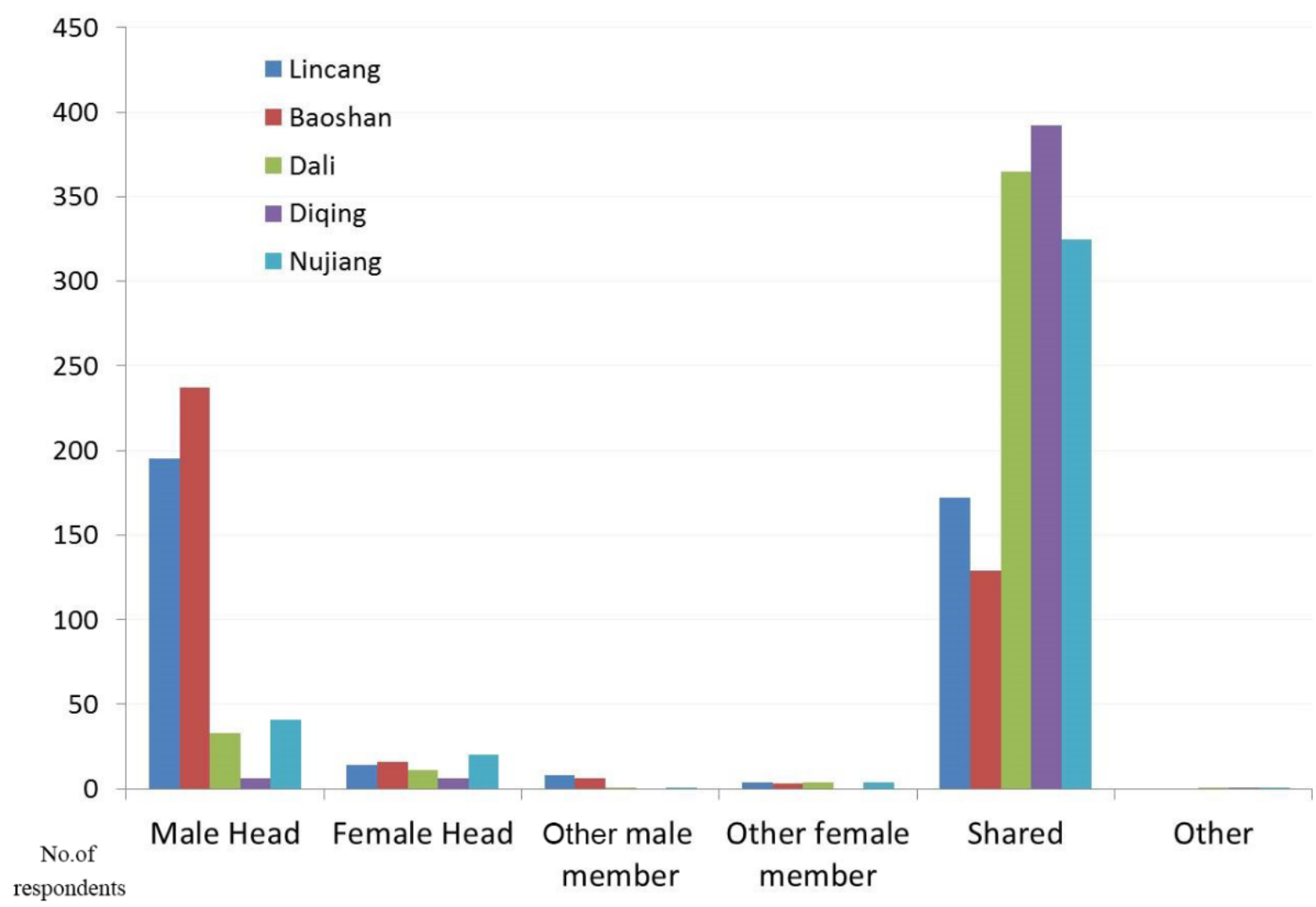

Figure 4 Ownership of housing

Construction materials used for exterior walls in our survey sites depended on location and local culture. Fired bricks and unfired bricks were the two most common types of construction materials throughout the survey sites. The least commonly used material varied from prefecture to prefecture.

When considering gender, $32 \%$ of male-headed households in Nujiang chose wood/branches as their exterior wall construction material, followed by $30 \%$ of maleheaded households who chose fired bricks. Thirty-three percent of female-headed 
households chose fired bricks to build exterior walls, followed by the $24 \%$ that chose wood/branches, and clay tiles respectively.

In Baoshan, about 35\% of male household heads would choose 'unfired bricks' (bricks dried in the sun) as their first option for exterior walls, followed by $33 \%$ who chose fired bricks. Of the female-headed households, $48 \%$ chose fired bricks as their first option for exterior walls, followed by $39 \%$ who chose unfired bricks.

Table 8 Construction materials for exterior walls of household home

\begin{tabular}{l|ll} 
& Most Common & Least Common \\
\hline Lincang & Fired Bricks, Unfired Bricks & Wood \\
\hline Baoshan & Fired Bricks & Concrete \\
\hline Dali & Fired Bricks & Metal/ Gl/ Asbestos sheets \\
\hline Diqing & Unfired Bricks & Stones, Thatch/Bamboo \\
\hline Nujiang & Fired Bricks & Stones
\end{tabular}

Types of construction materials for the main roof varied across every location except for households in Dali and Diqing, where tiles/shingles/slates were most common for the main roof. Concrete was used most frequently in Lincang and Nujiang, while straw/seeds or plastic/fabric was least used. Metal/Galvanised Iron (GI)/Asbestos sheets were the most common type of construction materials used in Nujiang.

Differences persisted between male and female-headed households' choices of construction materials for the main roof.

In Baoshan, the largest share of male-headed households (34\%) chose 'mud' as their main roof construction material, followed by $32 \%$ of male-headed households who chose 'tiles'. The largest share of female-headed households (also $34 \%$ ) chose 'tiles', followed by $23 \%$ who chose 'concrete' and 'mud', respectively.

In Nujiang, 51\% of male-headed households used 'metal' to construct their main roof, while $42 \%$ of female-headed households chose to use 'tiles' as the construction materials for the main roof. 
Table 9 Construction materials used for main roof of household home

\begin{tabular}{l|ll} 
& Most Common & Least Common \\
\hline Lincang & Concrete & Straw/ reeds, Plastic/Fabric \\
\hline Baoshan & Mud & Wood/Planks, Plastic/Fabric \\
\hline Dali & Tiles/ shingles/ slates & Plastic/Fabric \\
\hline Diqing & Tiles/ shingles/ slates & Thatch/ bamboo, Plastic/Fabric, \\
\hline Nujiang & Metal/ GI/ Asbestos sheets & Straw/ reeds, Plastic/Fabric
\end{tabular}

Table 10 Average number of rooms per household home

\begin{tabular}{|c|c|c|c|c|c|c|c|c|c|c|}
\hline & \multicolumn{2}{|c|}{ Lincang } & \multicolumn{2}{|c|}{ Baoshan } & \multicolumn{2}{|l|}{ Dali } & \multicolumn{2}{|c|}{ Diqing } & \multicolumn{2}{|c|}{ Nujiang } \\
\hline & $\begin{array}{l}\text { Male } \\
\mathrm{HH}\end{array}$ & $\begin{array}{l}\text { Female } \\
\mathrm{HH}\end{array}$ & $\begin{array}{l}\text { Male } \\
\mathrm{HH}\end{array}$ & $\begin{array}{l}\text { Female } \\
\mathrm{HH}\end{array}$ & $\begin{array}{l}\text { Male } \\
\mathrm{HH}\end{array}$ & $\begin{array}{l}\text { Female } \\
\mathrm{HH}\end{array}$ & $\begin{array}{l}\text { Male } \\
\mathrm{HH}\end{array}$ & $\begin{array}{l}\text { Female } \\
\mathrm{HH}\end{array}$ & $\begin{array}{l}\text { Male } \\
\mathrm{HH}\end{array}$ & $\begin{array}{l}\text { Female } \\
\mathrm{HH}\end{array}$ \\
\hline $\begin{array}{l}\text { No. of } \\
\text { Rooms }\end{array}$ & 3.83 & 3.27 & 3.85 & 3.57 & 4.73 & 4.86 & 6.5 & 6.33 & 4.14 & 5.08 \\
\hline
\end{tabular}

One of the questions included on this survey asked respondents to estimate the rent for rooms within their house. In this context, the term "expected value willingness to be paid" (Figure 6) reflects the minimum amount a seller thinks their product or service is worth. By having respondents assess their own homes against others in the area, a better picture of socio-economic status can be revealed rather than relying solely on incomes per annum. Both male and female-headed households in Baoshan, Diqing, Nujiang shared the same perception of price. In Dali, men tended to assess their homes as having a higher rental value than did women. On average, men gave a valuation that was 67 RMB more than women in Dali. The situation was reversed in Lincang, where women valued their home at a higher price, on average 99 RMB more than men.

It is interesting to note the potential connection between dependency ratio and housing price perceptions. In Lincang, women had the highest dependency ratio, and also were the most likely to assess their homes at a price higher than their male peers. Compare this to the case of men in Dali, who had the highest dependency ratio, and also the largest discrepancy compared to women when assessing their respective household value. 


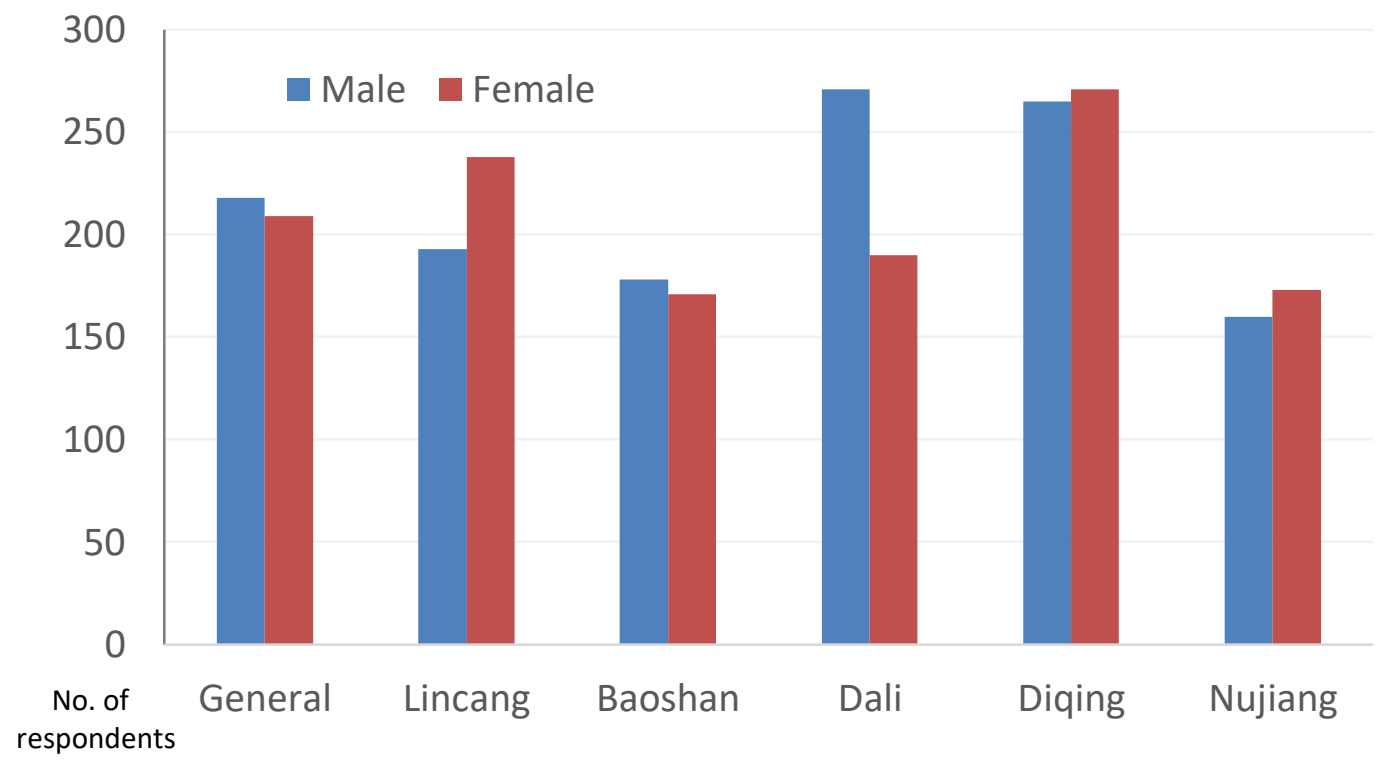

Figure 5 Surveyed households' excepted value for renting houses

\subsubsection{IIIness and affordability}

The ability to respond to illness is an important indicator of household financial stability and of a household's ability to respond to shocks and stresses. On a Likert scale, respondents were asked to rate the frequency of illnesses, with 1 representing "never" and 7 representing "every day" for both female and male family members, meaning the higher value, the more frequently experienced the illness. It was found that in general female family members are more vulnerable to illness, except in Nujiang.

Table 11 Level of illness of respondents in survey sites

\begin{tabular}{|l|l|l|l|l|l|}
\hline & Lincang & Baoshan & Dali & Diqing & Nujiang \\
\hline Male & 1.81 & 1.73 & 1.71 & 1.71 & 2.22 \\
\hline Female & 2.14 & 1.77 & 1.86 & 1.81 & 2.09 \\
\hline
\end{tabular}

Responding to illness often significantly impacts productive members of the family and responding to illness impacts the socio-economic status of the household. Access to affordable healthcare was tested in a Likert scale question, with 1 representing unaffordable and 6 representing highly affordable. Healthcare in Diqing was rated the highest in terms of affordability, and Lincang was rated the lowest. In Dali, Diqing, and Nujiang, women reported having access to affordable healthcare at higher rates than men. This indicates that they were more able to respond to illness. 
Table 12 Affordability of treatments for serious illness or injury

\begin{tabular}{|l|l|l|l|l|l|}
\hline & Lincang & Baoshan & Dali & Diqing & Nujiang \\
\hline Male & 3.58 & 3.83 & 4.54 & 4.75 & 4.04 \\
\hline Female & 3.16 & 3.51 & 4.6 & 4.85 & 4.23 \\
\hline
\end{tabular}

\subsection{Livelihoods, social networks and relations}

\subsubsection{Migration and off-farm jobs}

Migration affects gender roles, livelihoods, and social networking in several important ways, and our study found significant differences in migration trends according to gender and location. Generally, male-headed households had more productive members participate in migration regardless of the length of time spent working away from the respondent's home. In order to contextualize these statistics, it is important to remember that female-headed households are a smaller percentage of the total households surveyed throughout the five prefectures. It is possible that most female-headed households participate in migration, but that they make up a smaller percentile of total respondents.

Each prefecture has its own anomalies, producing several seemingly random trends over the entire distribution of the migration patterns attained in this survey. In Lincang prefecture, $80 \%$ of female-headed households reported male members of the household migrated for over 10 months to a different town or village within the country. This compared to $61 \%$ of male-headed households. In contrast, when looking at migration over the same time period for female members of the household, the proportion dropped to $56 \%$ of female-headed households, but rose slightly for male-headed households to $62 \%$. 
Table 13. Migration Patterns

\begin{tabular}{|l|c|c|c|c|}
\hline Items & $0-3$ months & $4-6$ months & $7-10$ months & over 10 months \\
\hline All Male & $8 \%$ & $14 \%$ & $16 \%$ & $62 \%$ \\
\hline All Female & $9 \%$ & $21 \%$ & $10 \%$ & $60 \%$ \\
\hline Lincang Male & $9 \%$ & $15 \%$ & $13 \%$ & $63 \%$ \\
\hline Lincang Female & $9 \%$ & $21 \%$ & $8 \%$ & $62 \%$ \\
\hline Baoshan_Male & $7 \%$ & $15 \%$ & $13 \%$ & $64 \%$ \\
\hline Baoshan_Female & $15 \%$ & $18 \%$ & $9 \%$ & $58 \%$ \\
\hline Dali_Male & $6 \%$ & $12 \%$ & $18 \%$ & $65 \%$ \\
\hline Dali_Female & $8 \%$ & $21 \%$ & $8 \%$ & $64 \%$ \\
\hline Diqing_Male & $5 \%$ & $11 \%$ & $19 \%$ & $65 \%$ \\
\hline Diqing_Female & $4 \%$ & $15 \%$ & $17 \%$ & $65 \%$ \\
\hline Nujiang_Male & $16 \%$ & $19 \%$ & $18 \%$ & $47 \%$ \\
\hline Nujiang_Female & $6 \%$ & $33 \%$ & $9 \%$ & $52 \%$ \\
\hline
\end{tabular}

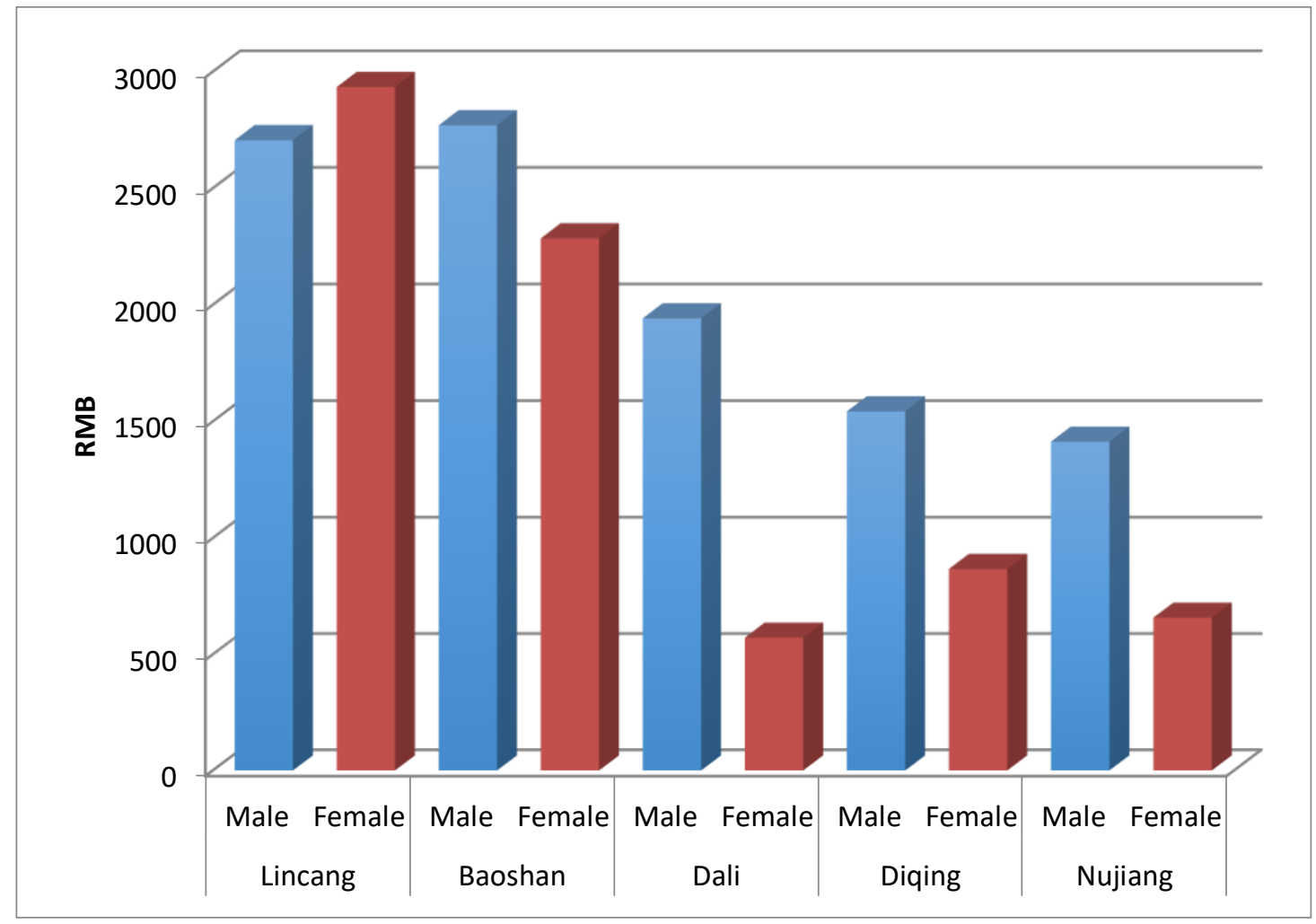

Figure 6 Total remittance per person

Despite having similar migration patterns, remittances varied between men and women. On average, male migrants remitted double the amount that female migrants did, which may reflect the fact that women are paid less than men for off-farm jobs in China (Xu and Tian, 2015). Lincang was an exception to this trend, as women remitted slightly more than 
men. Geographically, migrants in Lincang and Baoshan remitted much more than other prefectures. Households in Nujiang received the least remittances on average.

\subsubsection{Gender roles and responsibilities}

The rights of women to work independently outside the home were restricted in the late Ming and early Qing dynasties (Feng, 2006). Despite the progress made towards recognizing women's contributions to the nation's economy, gender equity in China remains an ideal rather than a reality.

China's rapid social and economic changes reflected changes in gender roles both inside and outside of households. This was specifically seen in the changing division of labour throughout the prefectures. In general, $81.3 \%$ of women claimed to participate in cooking and cleaning, with $83 \%$ of female household heads reporting involvement in these activities. Less than $0.8 \%$ of men reported such activities, with $0.7 \%$ of male household heads reporting involvement. Half of the female respondents reported participating in work such as feeding animals, cleaning cattle sheds, and collecting fodder, with $32 \%$ of male respondents reporting involvement. Both men and women reported participating in activities such as compost making ( $17 \%$ vs $14 \%)$, irrigating fields ( $14 \%$ vs $15 \%)$, and storing the harvest ( $14 \%$ vs $10 \%$ ), but men were far less likely to report caring for young children (4\% vs $28 \%$ ). Notably, ploughing and firewood collection were the only two events in which a majority of men participated. In all other areas, less than a quarter of men said they participated. Division of labour did not vary based on geographical location or ethnicity.

In Lincang, around $60 \%$ of men and $30 \%$ of women worked in construction. The manufacturing sector was the most popular sector of employment for women and the second most popular for men. A very limited number of men and women reported working in health and social work, or in the electricity, gas, and water supply fields. 


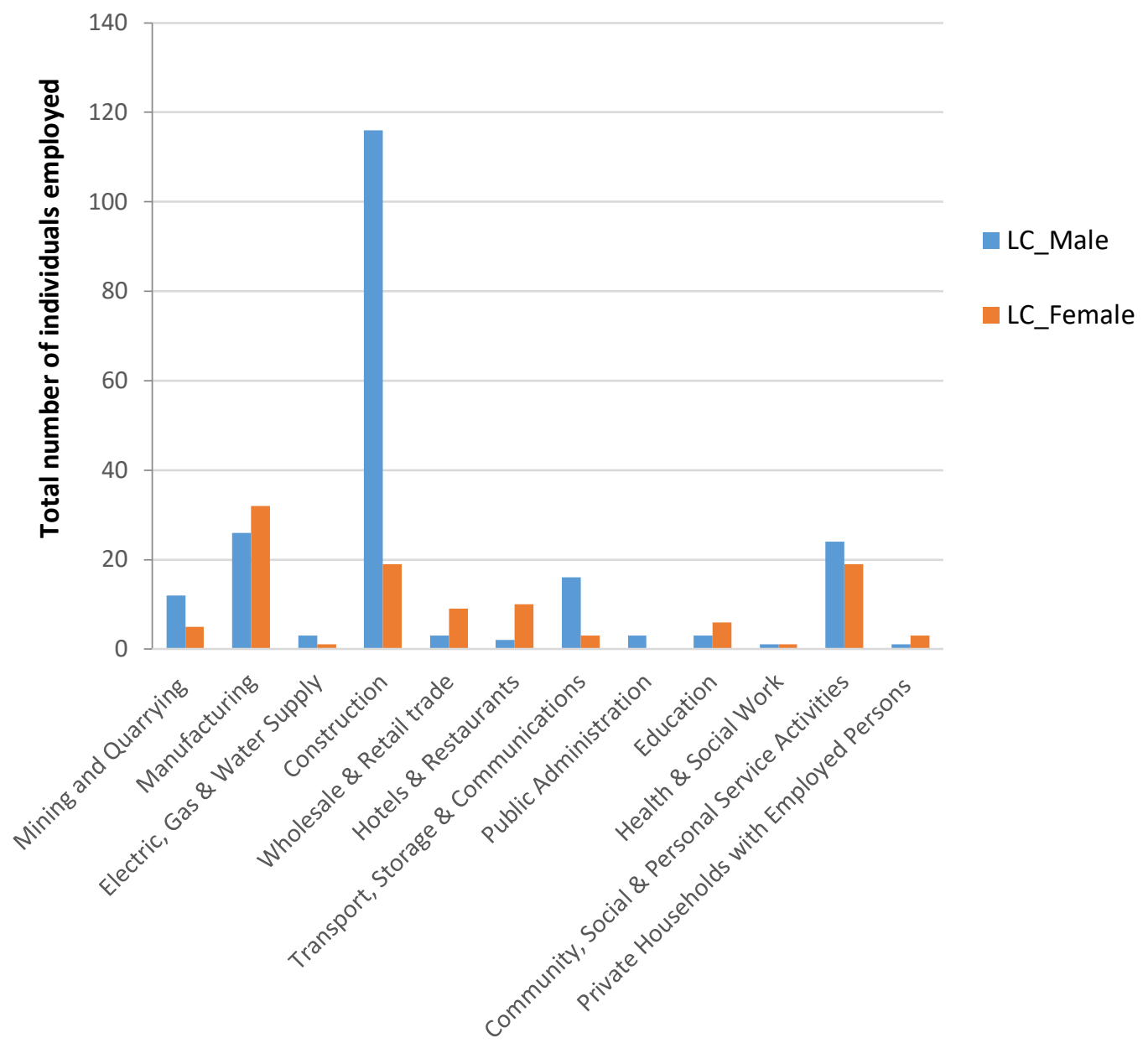

Figure 7 Sectors of employment based on individual participation in Lincang 
In Baoshan, $54 \%$ of male respondents were working in construction and around $25 \%$ were working in manufacturing. The most prevalent sector for female employment was manufacturing, followed by community, social, and personal service activities.

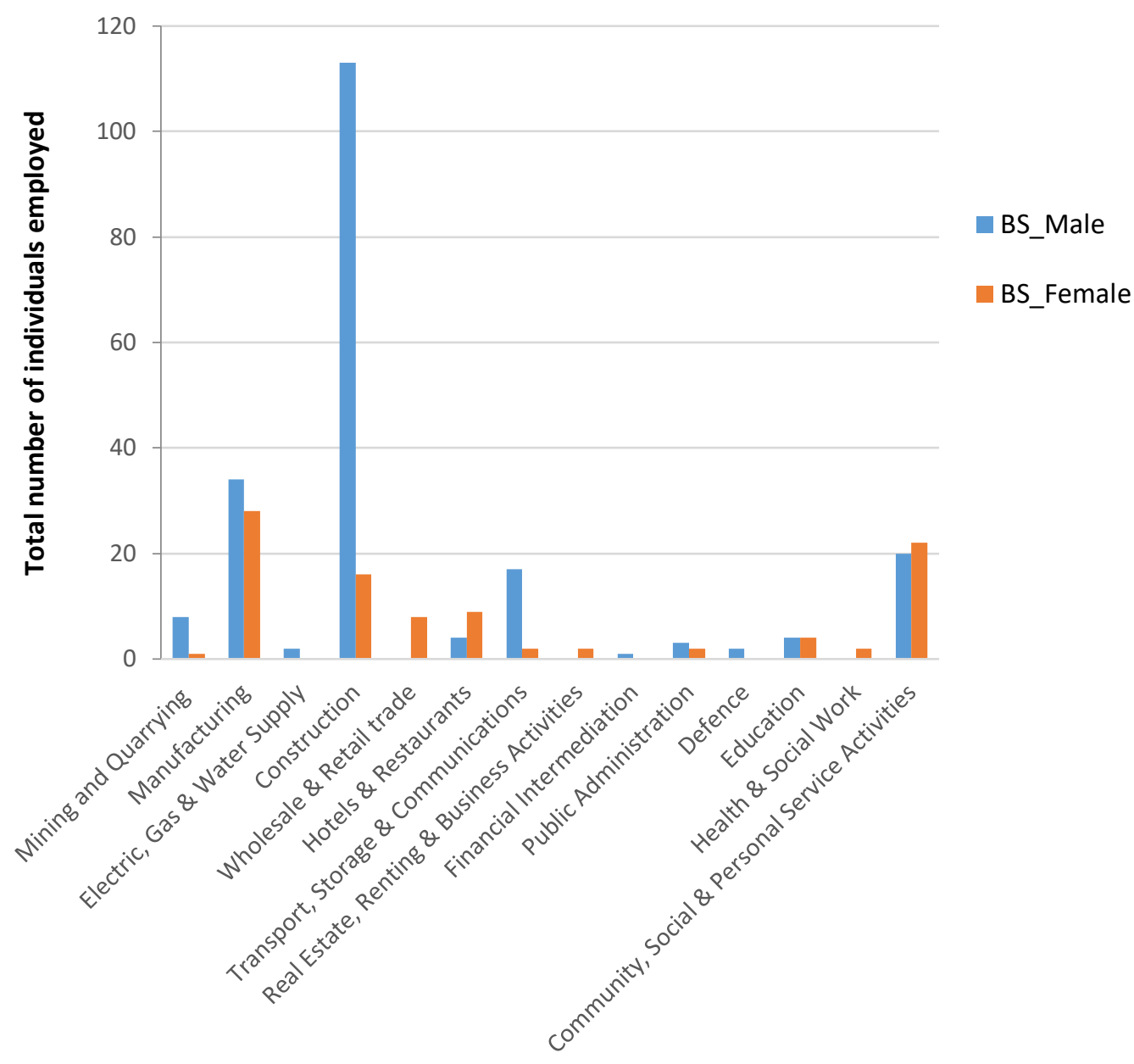

Figure 8 Sectors of employment based on individual participation in Baoshan 
The majority of men in Dali worked in construction, transport, storage, and communications, while female labour was more evenly distributed between construction, wholesale and retail trade, education, hotels and restaurants, and other sectors.

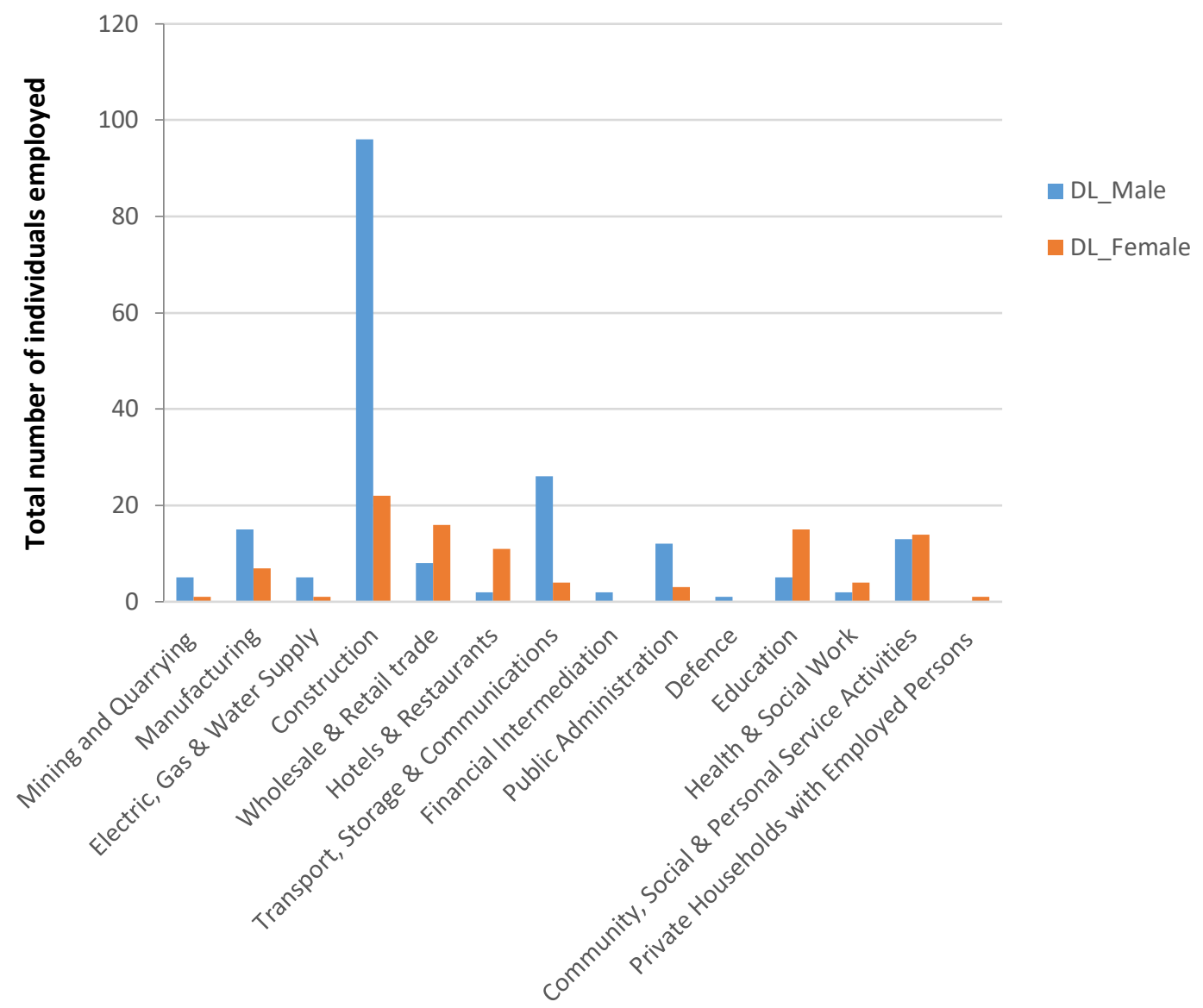

Figure 9 Sectors of employment based on individual participation in Dali

The occupational distribution of men and women in Diqing was also heavily influenced by gender. Men most commonly worked in construction, followed by transport, storage, and communication, and finally social and personal service activities. Females were more likely to work in wholesale and retail trade, social and personal service, and transport, storage, and communications. 


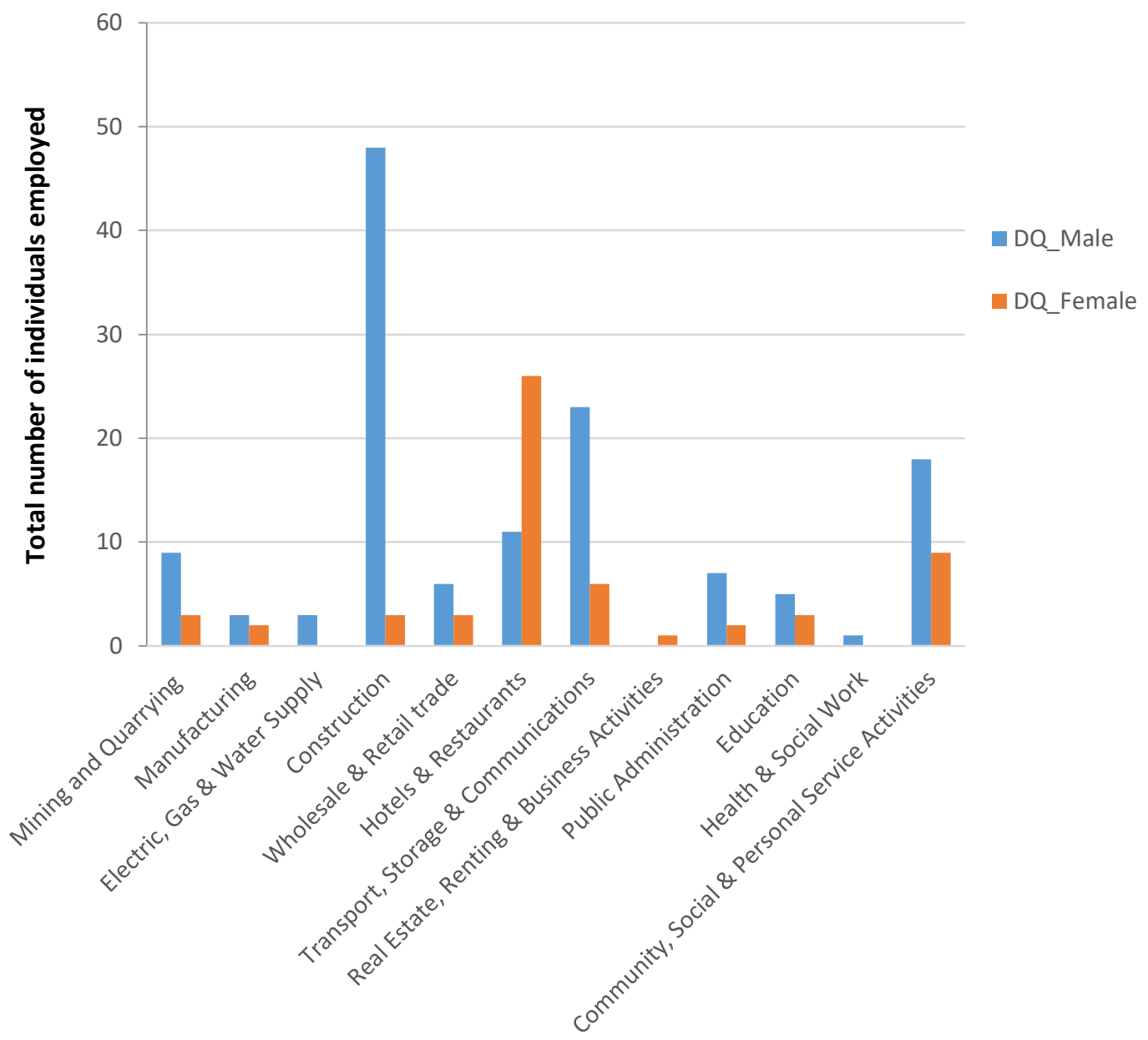

Figure 10 Sectors of employment based on individual participation in Diqing

The role of gender in determining occupational differences was also recorded in Nujiang. Most men worked in construction, followed by transport, storage, and communications. Female labour was evenly distributed between hotels and restaurants, construction, and other sectors. 


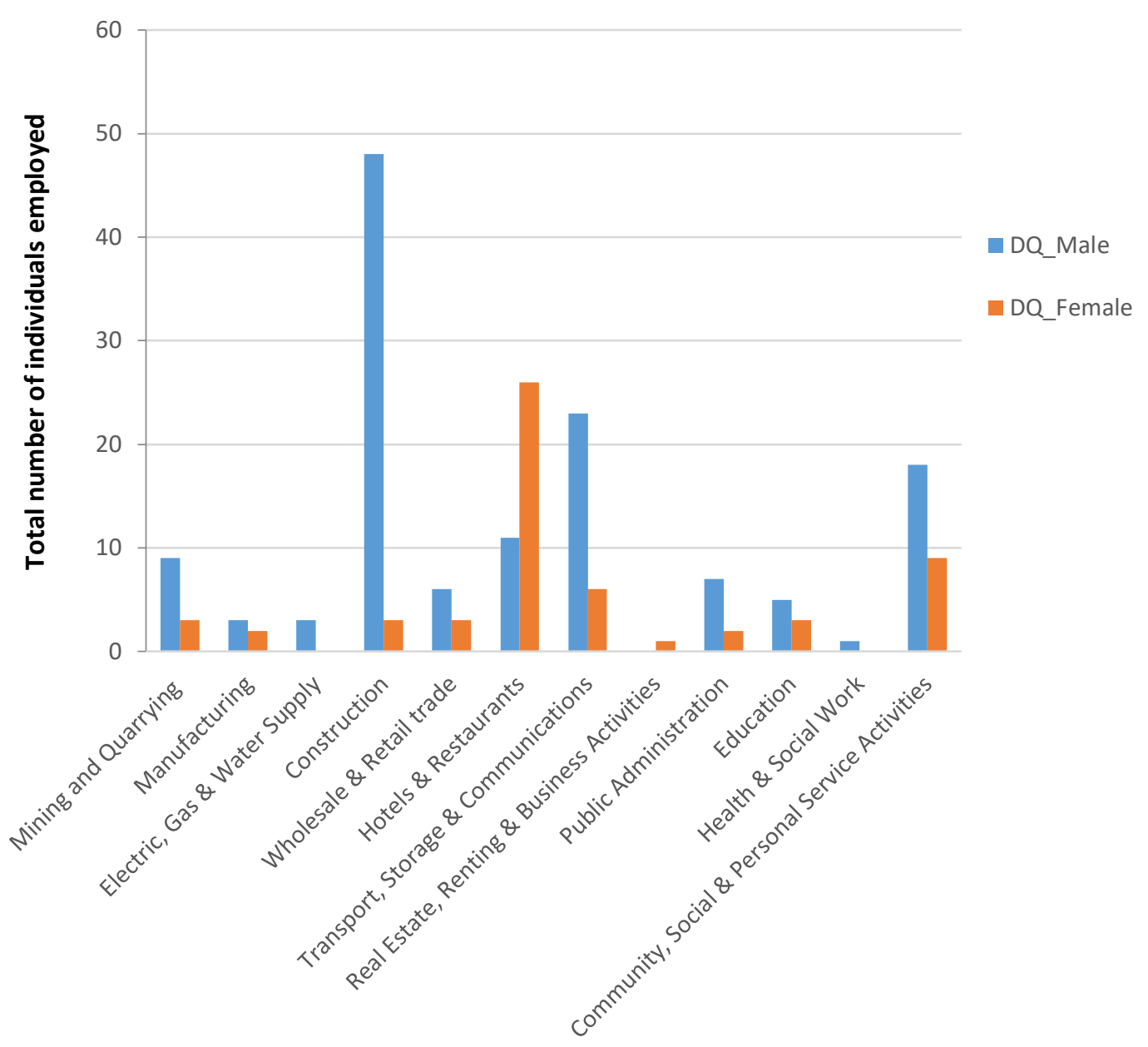

Figure 11 Sectors of employment based on individual participation in Nujiang

\subsubsection{Participation in decision-making}

The number of women participating and influencing decision-making at different levels in China, including high level decision-making, is still very low (Liu, 2015). Decision-making and governance are often considered male responsibilities (Liu, 2015) which serve to further marginalize women. In our study, the ability to influence decision-making at local and regional levels was recorded using Likert scale questions, with separate questions about each level of decision-making. At each level, respondents were asked to rate the difficulty of influencing local or regional governments, with 1 being very difficult and 5 being very easy. The first question examined the accessibility of local decision-making.

There was a difference between male and female involvement in decision-making at the local level. Generally, the percentage of women who believed that it was very difficult to influence decision-making at the local level was double that of men. However, geographical location was an important factor in local decision-making. Around $47 \%$ of women surveyed in Lincang felt that it was difficult or very difficult to influence the decision making at the local level, while only $39 \%$ of men responded in the same way. Respondents in Baoshan reported an even greater contrast: $47 \%$ of surveyed women stated that it was very difficult to influence local decision-making processes, while only 
around $12 \%$ of men held this view. Differences in access to decision-making at the local level were also observed in Diqing and Nujiang prefectures, but these were less dramatic.

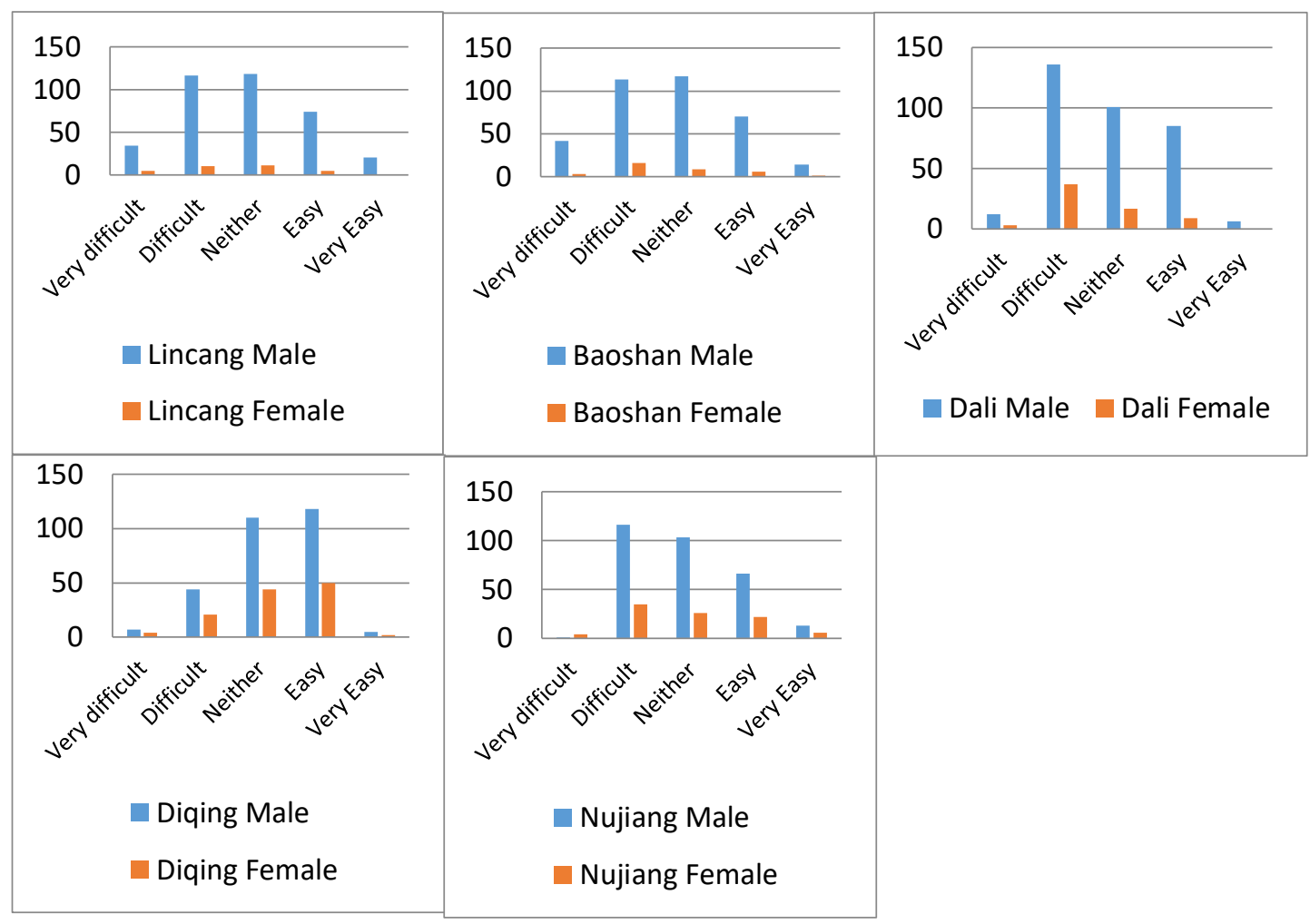

Figure 12 Perception of influence on local level decision-making

The majority of both male and female participants claimed that it was very difficult to influence decision-making at the county level. However, unlike in the other areas, women in Diqing were more positive about their influence on decision-making at the county level than were men. In all the other prefectures, men had more access to the decision-making processes. The gender gap was most dramatic in Baoshan, where over $45 \%$ of women reported that it was very difficult to influence decision-making processes at the county level.

Table 14 Decision making at county or above level

\begin{tabular}{|l|l|l|l|l|l|l|}
\hline \multicolumn{1}{|c}{ Prefecture } & Gender & Very difficult & Difficult & Neither & Easy & Very Easy \\
\hline \multirow{2}{*}{ Lincang } & Male & 174 & 54 & 100 & 29 & 5 \\
& Female & 17 & 4 & 7 & 3 & 0 \\
\hline \multirow{2}{*}{ Baoshan } & Male & 162 & 58 & 112 & 21 & 3 \\
\hline \multirow{2}{*}{ Dali } & Female & 16 & 10 & 7 & 2 & 0 \\
\hline \multirow{2}{*}{ Diqing } & Male & 149 & 86 & 71 & 33 & 1 \\
& Female & 37 & 19 & 5 & 0 & 5 \\
\hline \multirow{2}{*}{ Nujiang } & Male & 86 & 68 & 76 & 51 & 3 \\
& Female & 38 & 22 & 34 & 26 & 1 \\
\hline & Male & 96 & 94 & 74 & 34 & 1 \\
& Female & 27 & 30 & 30 & 3 & 3
\end{tabular}


In several areas of the world, studies have found that community organizations play an important role in empowering women who are marginalized and have very limited influence on decision making. Community-based organizations have been utilized widely as a way to include marginalized groups, including women, in resource management at the grassroots level (Chaskin, 2001). Diqing had the highest rates of participation in community level organizations for both men (55\%) and women (59\%), meaning that over half of the respondents surveyed in this prefecture were involved in a community organization. Lincang had the lowest rates of participation with only $8 \%$ of male respondents and $3 \%$ of female respondents reporting involvement. Lincang was the only prefecture to show a significant disparity between genders in participation rates; all the other areas reported similar rates of participation for men and women.

Table 15 Membership of households in community organizations

\begin{tabular}{|l|l|l|l|l|l|}
\hline Gender & Lincang & Baoshan & Dali & Diqing & Nujiang \\
\hline Male & $7.69 \%$ & $6.09 \%$ & $13.78 \%$ & $54.81 \%$ & $17.63 \%$ \\
\hline Female & $2.72 \%$ & $7.25 \%$ & $14.50 \%$ & $58.91 \%$ & $16.62 \%$ \\
\hline
\end{tabular}

Participation in women's groups was highly diverse throughout the prefectures. Generally, women were more likely to participate in women's organizations, except in Diqing where $72 \%$ of male respondents participated in women's groups. In Baoshan, there was no participation in women's groups by either gender. In Dali, Nujiang and Lincang, women participated in women's groups at a higher rate than men.

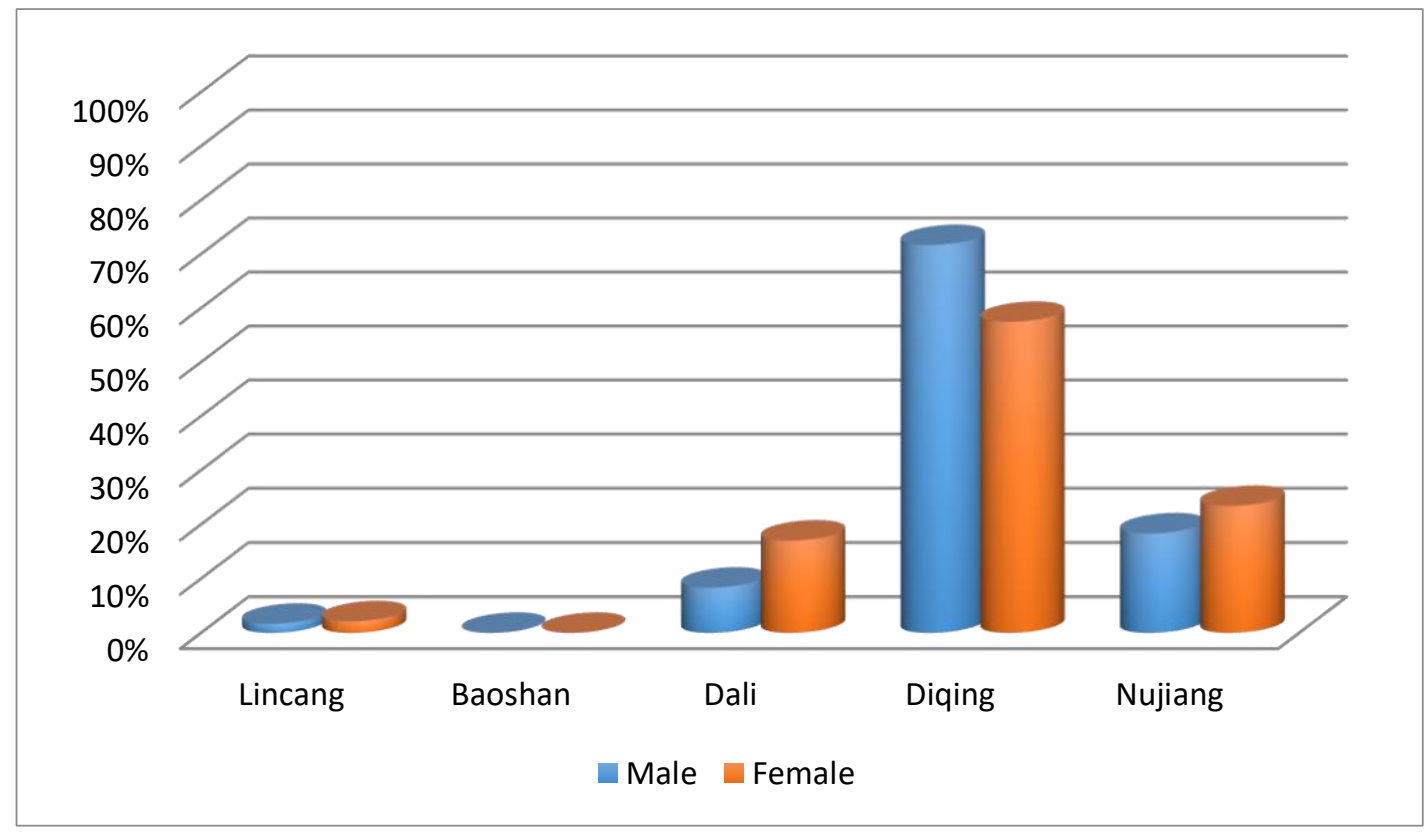

Figure 13 Individual participation in women's organizations 
Table 16 Membership of households in women's organizations

\begin{tabular}{|l|l|l|l|l|l|}
\hline & Lincang & Baoshan & Dali & Diqing & Nujiang \\
\hline Male & $1.67 \%$ & $0.00 \%$ & $8.33 \%$ & $71.67 \%$ & $18.33 \%$ \\
\hline Female & $2.13 \%$ & $0.00 \%$ & $17.02 \%$ & $57.45 \%$ & $23.40 \%$ \\
\hline
\end{tabular}

\subsection{Access to land and other resources}

\subsubsection{Access to agricultural land}

The level of access to community forest varied in each prefecture, and was highly dependent on county regulations, village orders, and forestry laws. Ninety-eight percent of respondents from Dali, Diqing, and Nujiang stated that they had free year-round access to land. Baoshan had the lowest rate of year-round accessibility, with $74 \%$ of men and $80 \%$ of women with year-round access, respectively. A large majority of respondents claimed that they could access community forests at some point during the year, even if they did not have free year-round access. Lincang and Baoshan were the only prefectures where respondents of both genders claimed they had no access to community forests. In Lincang, $9 \%$ of total respondents reported no access to community forests. In Baoshan this number increased to around $20 \%$ of total respondents.

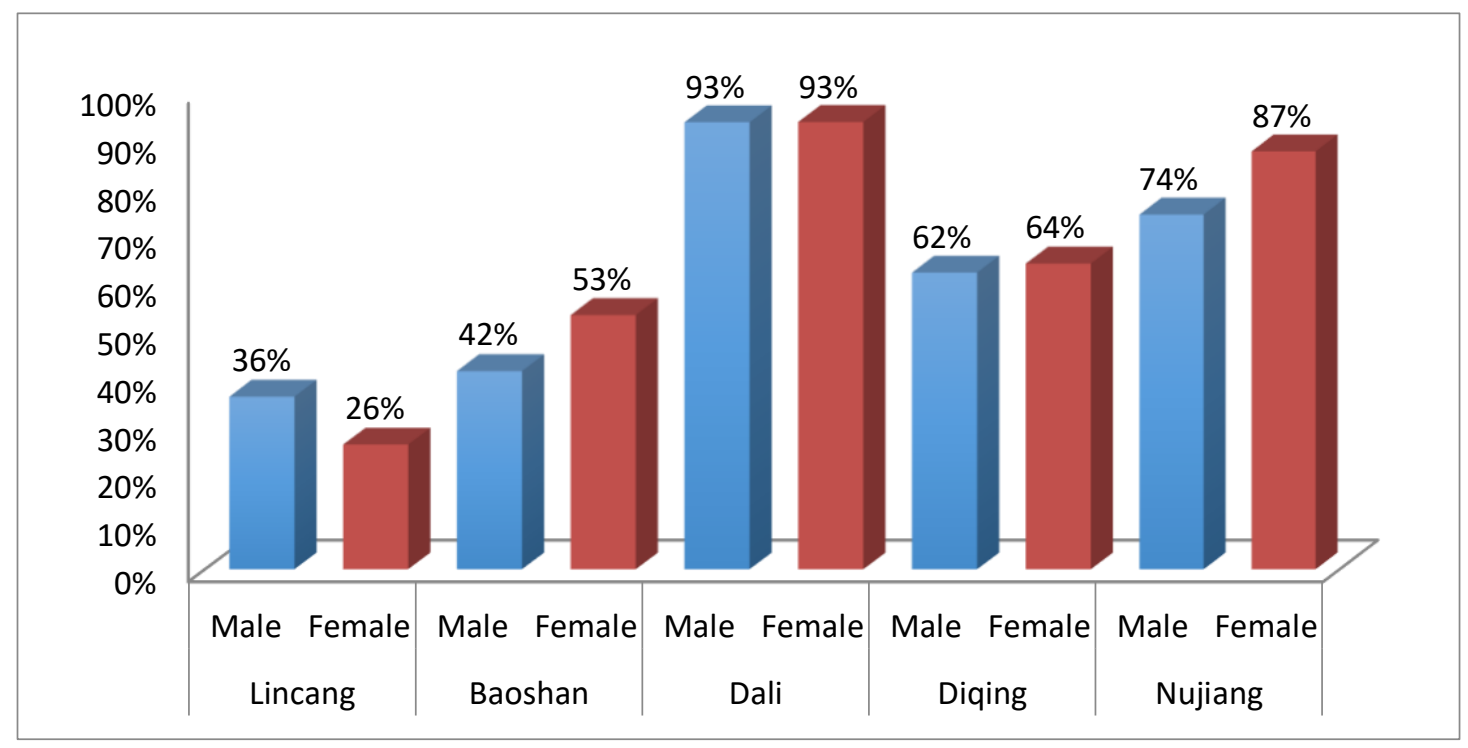

Figure 14 Share of households with year-round access to community forests 


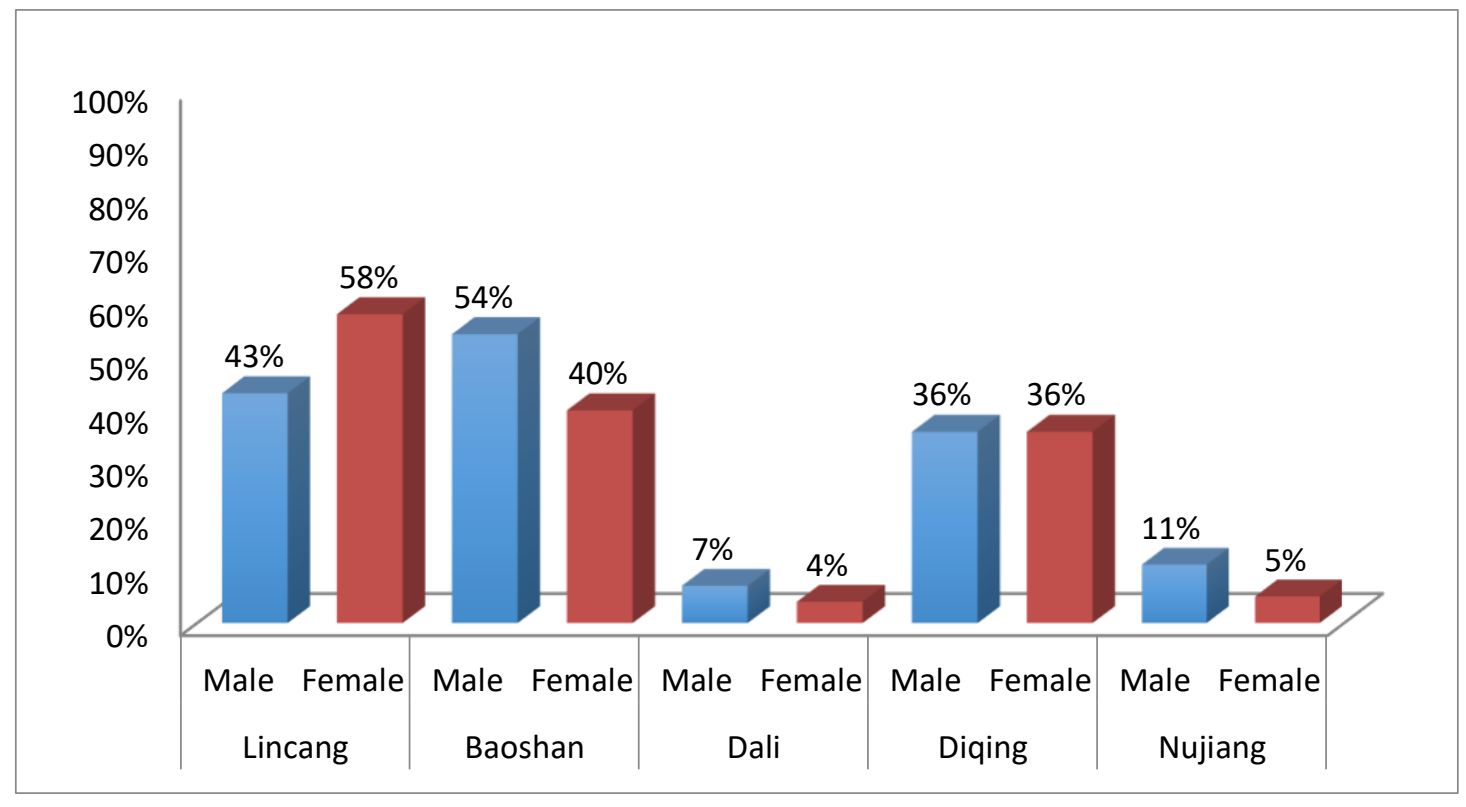

Figure 15 Share of households with no access to community forests

Unlike community forests, accessibility to protected areas displayed a more diverse pattern. This may be due to the differences in access at different levels of protected areas, such as local, provincial and national level protected areas, or to different management regimes in different areas. National level protected areas have been established in Weixi (Diqing), Lushui (Nujiang), Longyang (Baoshan) and Youde (Lincang) counties (The Nature Conservancy, 2010). In 2008, Yunnan was designated as a pilot for national parks and, therefore, receives additional funds from the provincial and national government in order to support staff, patrols and better protection measures (The Nature Conservancy, 2010). Although many protected areas are often underfunded, these areas may still be betterpatrolled then community forest areas. Households in Dali had the most access to protected areas, most likely because Dali does not have a national level protected area. Ninety-three percent of the respondents in Dali reported access to protected areas. Respondents in Lincang had the lowest access to protected areas. In both Nujiang and Baoshan, women had more access than men to protected areas.

Compared to community forests, a much higher percentage of respondents stated that they had no access to protected areas. Women in Lincang had the least access to protected areas (60\% of female respondents reported no access). In contrast, $43 \%$ of males reported no access to protected areas. Men in Baoshan reported the second highest rate of lack of access. 


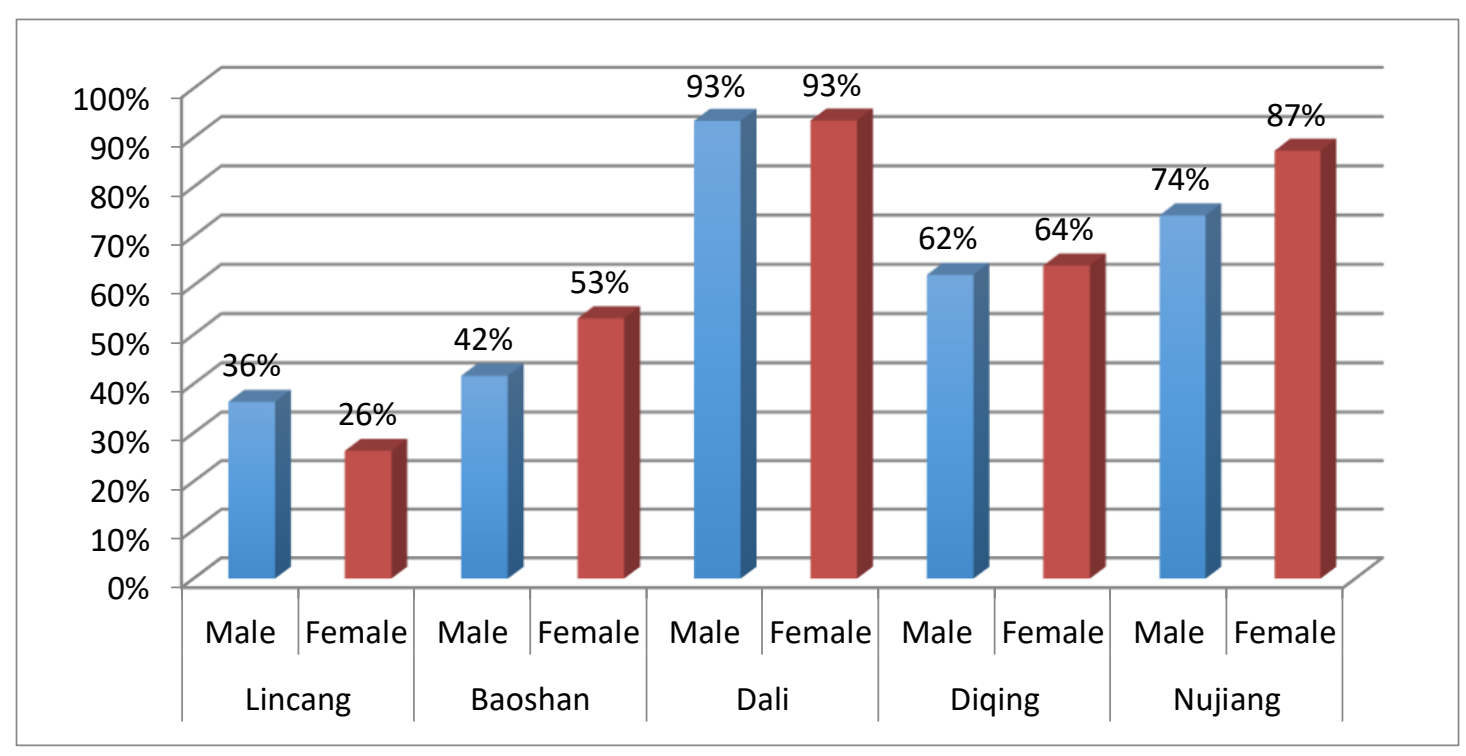

Figure 16 Share of households with year-round access to protected areas

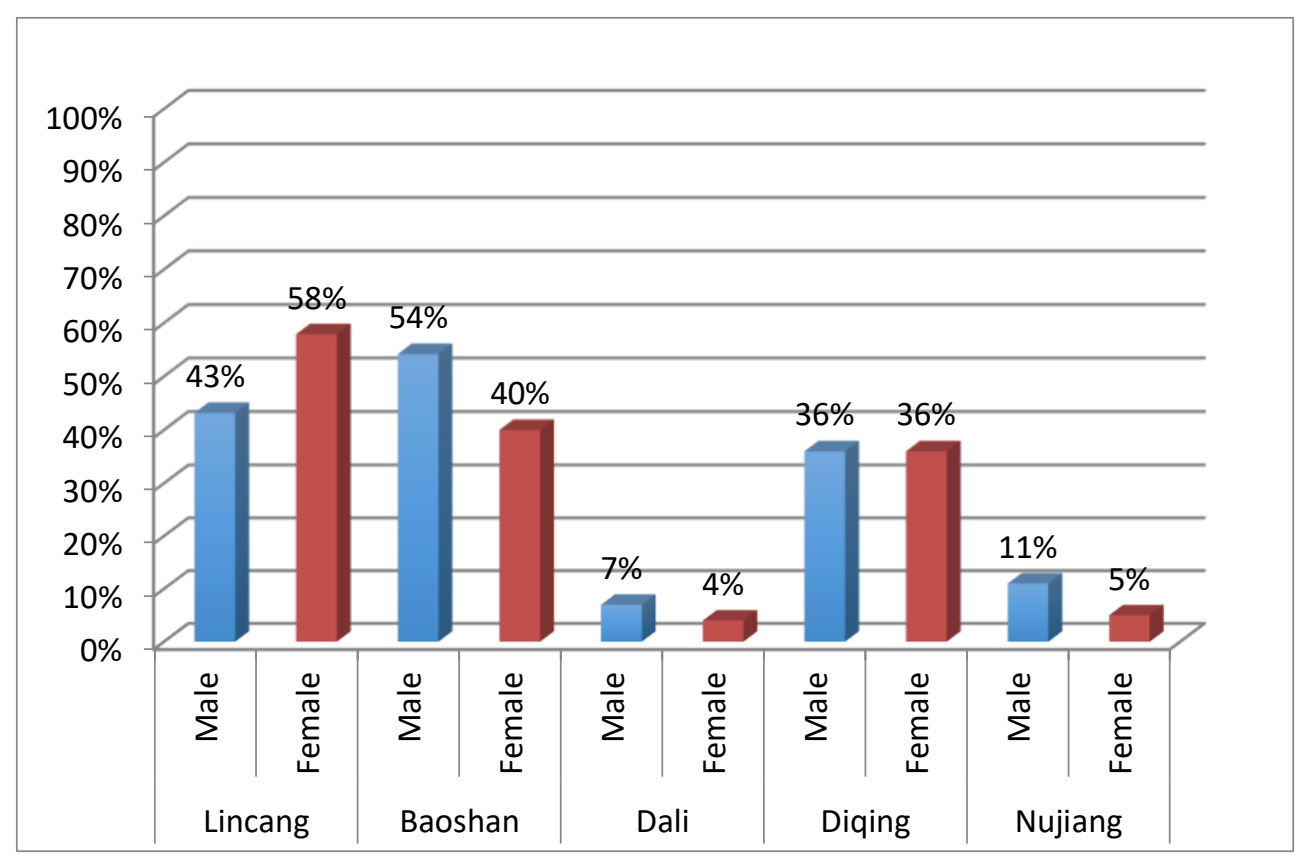

Figure 17 Share of households with no access to protected areas

\subsubsection{Access to resources and networks}

Access to social networks and resources are extremely important factors when understanding vulnerability and adaptability. If a household has access to social networks and resources, then they are typically better able to respond to shocks and stresses. One of the most common coping techniques to offset a shock is through a loan. The survey results indicated that gender does not play a significant role in determining male and female perceptions of access to loans. In Diqing, $66 \%$ of men and $75 \%$ of women agreed that getting a loan was easy. However, in Nujiang, $56 \%$ of men and $53 \%$ of women believed it was easy to access a loan. 
In general, $16 \%$ of respondents found that it was neither difficult nor easy to access a loan, and there was no significant variance between genders. In Lincang, Dali and Diqing, 65\% of female-heads of household found it easy to access a loan.

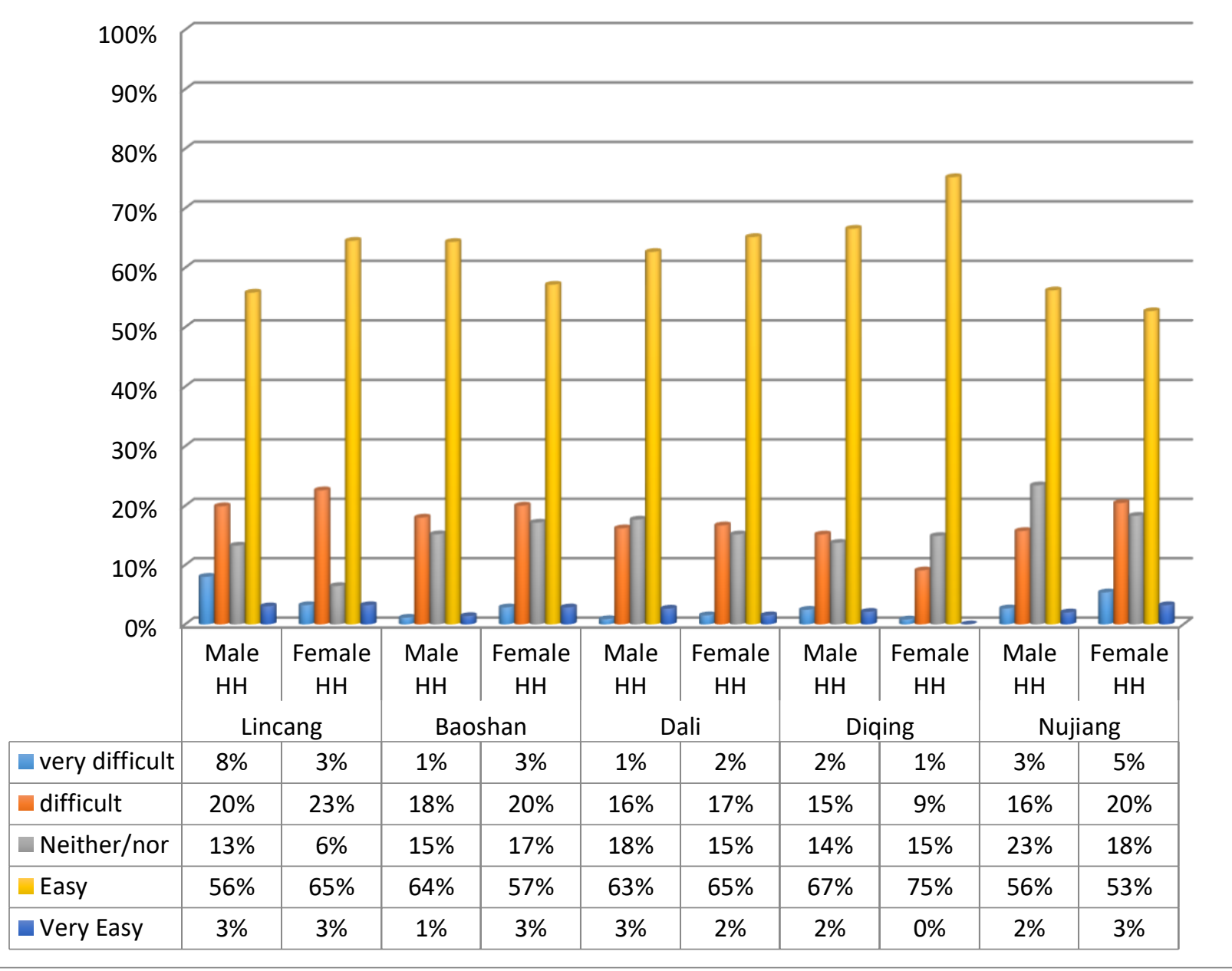

Figure 18 Perception of ease of access to loans

The ability to access loans was strongly correlated with the amount of debt a household had accumulated. In general, most households surveyed were debt free. On average, $22 \%$ of households in Dali, Nujiang, and Diqing reported a moderate amount of debt, while those in Baoshan and Lincang reported higher average incidences of debt per household. There were two significant instances where gender had a strong impact on debt. In Lincang, female-headed households reported having debts totalling $13 \%$ higher than those of male-headed households. Women in Lincang were $15 \%$ more likely than men to report easy access to loans. In Nujiang, male-headed households reported debts at a 13\% higher rate than female-headed households; however, they reported similar rates of ease of access to loans. In the other prefectures, all households experienced debt at similar rates. 
Table 17 Levels of reported debt

\begin{tabular}{|l|c|c|c|c|}
\hline Debt & None & A little & Moderate & A lot \\
\hline Lincang-Male & $54 \%$ & $6 \%$ & $21 \%$ & $19 \%$ \\
\hline $\begin{array}{l}\text { Lincang- } \\
\text { Female }\end{array}$ & $42 \%$ & $6 \%$ & $19 \%$ & $32 \%$ \\
\hline Baoshan_Male & $42 \%$ & $5 \%$ & $25 \%$ & $28 \%$ \\
\hline $\begin{array}{l}\text { Baoshan- } \\
\text { Female }\end{array}$ & $43 \%$ & $3 \%$ & $23 \%$ & $31 \%$ \\
\hline Dali-Male & $55 \%$ & $6 \%$ & $25 \%$ & $14 \%$ \\
\hline Dali-Female & $58 \%$ & $5 \%$ & $21 \%$ & $17 \%$ \\
\hline Diqing-Male & $70 \%$ & $5 \%$ & $18 \%$ & $7 \%$ \\
\hline Diqing-Female & $68 \%$ & $2 \%$ & $23 \%$ & $7 \%$ \\
\hline $\begin{array}{l}\text { Nujiang-Male } \\
\text { Nujiang- }\end{array}$ & $71 \%$ & $5 \%$ & $14 \%$ & $10 \%$ \\
\hline Female & $57 \%$ & $2 \%$ & $27 \%$ & $14 \%$ \\
\hline
\end{tabular}

\subsection{Economic characteristics}

\subsubsection{Income and Revenue}

Household income is made up of many different activities which vary by gender and location. Across all of the prefectures, crops and daily wages were the most significant contributors to household income. While these two income sources were important to all households, significant differences were found in other areas. Geographically, two trends related to income were apparent: First, Dali and Diqing derived a more significant percent of income from tourism than other areas. Second, Nujiang's respondents received at least $12 \%$ more government benefits than all the other prefectures.

In Lincang, Baoshan and Nujiang, female-headed households relied more on salary than male-headed households. In Lincang and Baoshan, remittances to female-headed households contributed a higher percentage of total income than remittance to maleheaded households in the same region. In Baoshan, Dali and Nujiang, livestock had a more prevalent role in male-headed households. In Diqing, gender seemed to have no effect on income-generating activities. 


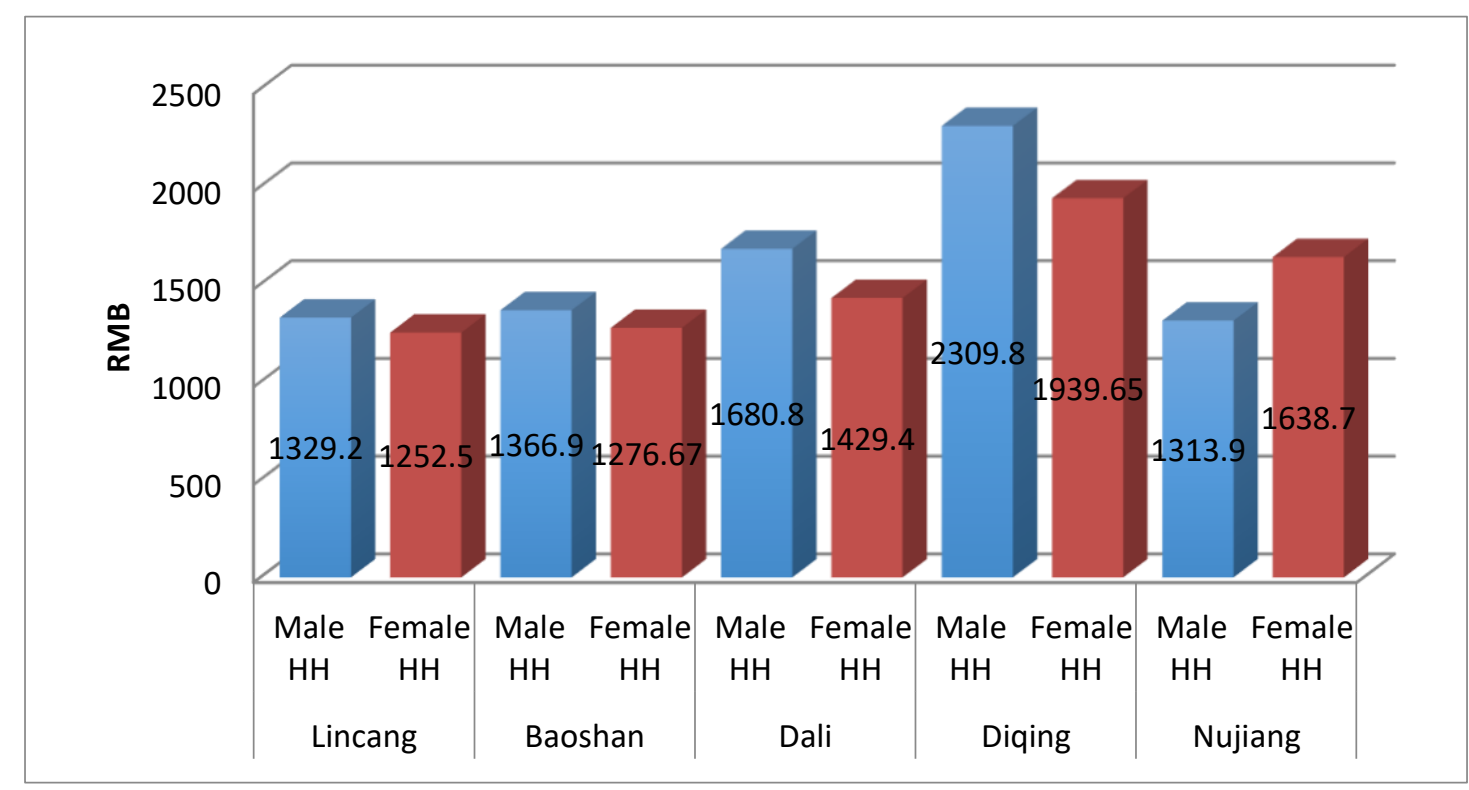

Figure 19 Income per household

\subsubsection{Farming Practices and Perceptions of Changes in Yield}

Survey results revealed that similar staple crops were planted throughout all the study sites. In all prefectures the most common staple crop was summer maize, except in Dali where paddy rice was more common. Paddy rice as referred to in this paper is defined as rice planted in the spring season on a partially flooded piece of arable land. In Baoshan, Diqing and Nujiang, there was very little difference in the staple crops. In Diqing and Nujiang, gender differences began to affect the fifth most common staple crop by very small percentages. In Baoshan, the fourth most important staple crop varied according to gender by less than 10 percent, and both male and female-headed households identified barley as the fifth most important staple crop. Respondents from Dali and Lincang, however, identified significantly different crops depending on their gender. In Lincang, male-headed households planted two crops of wheat, while female-headed households planted two crops of potato. In Dali, female-headed households planted two crops of maize and wheat, while male-headed households planted barley, peas and legumes.

It is clear that more households focused their planting efforts on planting staple crops rather than cash crops. However cash crops, unlike staple crops, showed a great deal of geographic diversity. Forty percent of households in Lincang, regardless of gender, identified tea as the most important cash crop, but while men in Lincang also planted tobacco, women tended to plant winter potato. Similarly, in Diqing over $40 \%$ of all households planted walnuts as well as other fruits, but male-headed households also planted garlic and paddy rice, while female-headed households focused on onion and summer vegetables as cash crops. In Nujiang, women and men planted very similar crops, except that men identified tea and sugarcane as important cash crops, while women chose winter vegetables and summer maize.

\section{Lincang}


For households in Lincang, no significant gender differences were detected in staple crop production. Over $50 \%$ of both male and female households believe yields of summer maize have increased in the last 10 years. Sixty-two percent of male-headed households described no change in yields of summer vegetables, and a $71 \%$ decrease in yields of winter maize. Seventy-five percent of female-headed households reported an increase in winter potato yields, while no outstanding consensus was reported about summer potato. In contrast, $100 \%$ of female-headed households claimed that early paddy rice yields had decreased. 


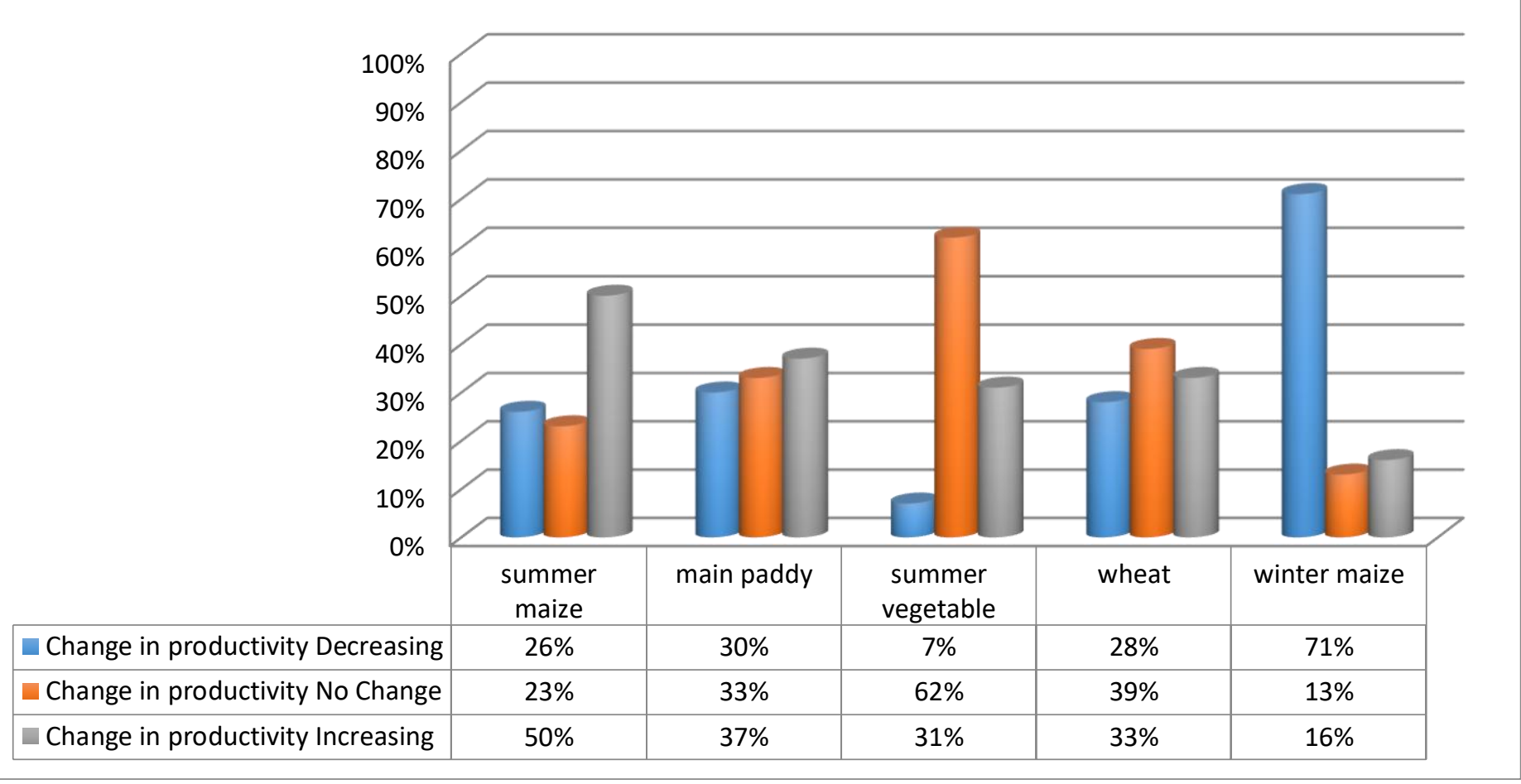

Figure 20 Perception of productivity change in staple crops in male-headed households in Lincang

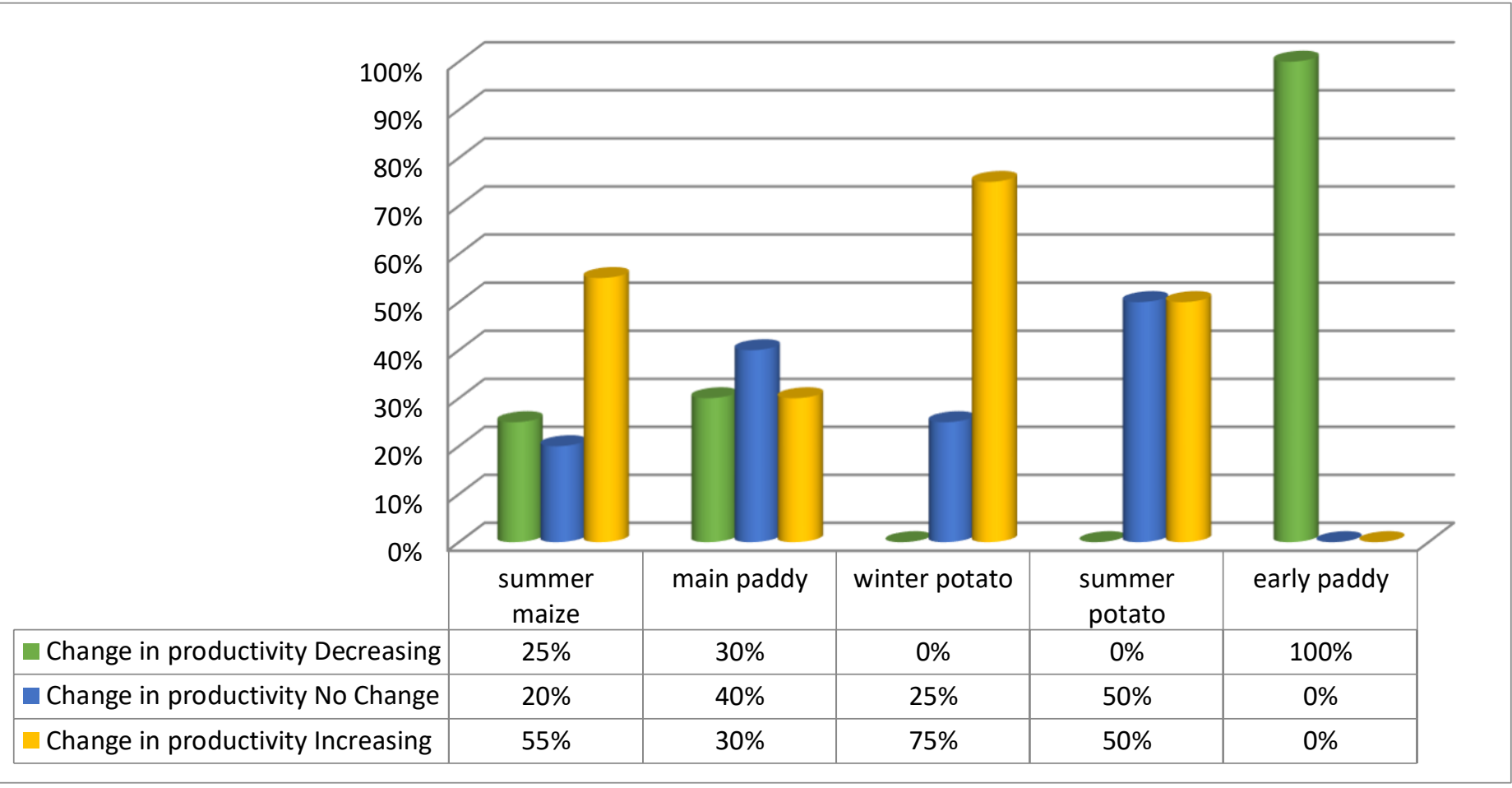

Figure 21 Perception of productivity change in staple crops in female-headed households in Lincang

\section{Baoshan}

Male-headed households produced more wheat and barley than female-headed households, but less paddy rice. Over $70 \%$ of male-headed households claimed that yields of winter maize had decreased, which is the same as the result for Lincang. Thirty percent 
of male-headed households and $50 \%$ of female-headed households reported that barley production had decreased. The majority of female-headed households described no change in the yield of wheat and other staple crops.

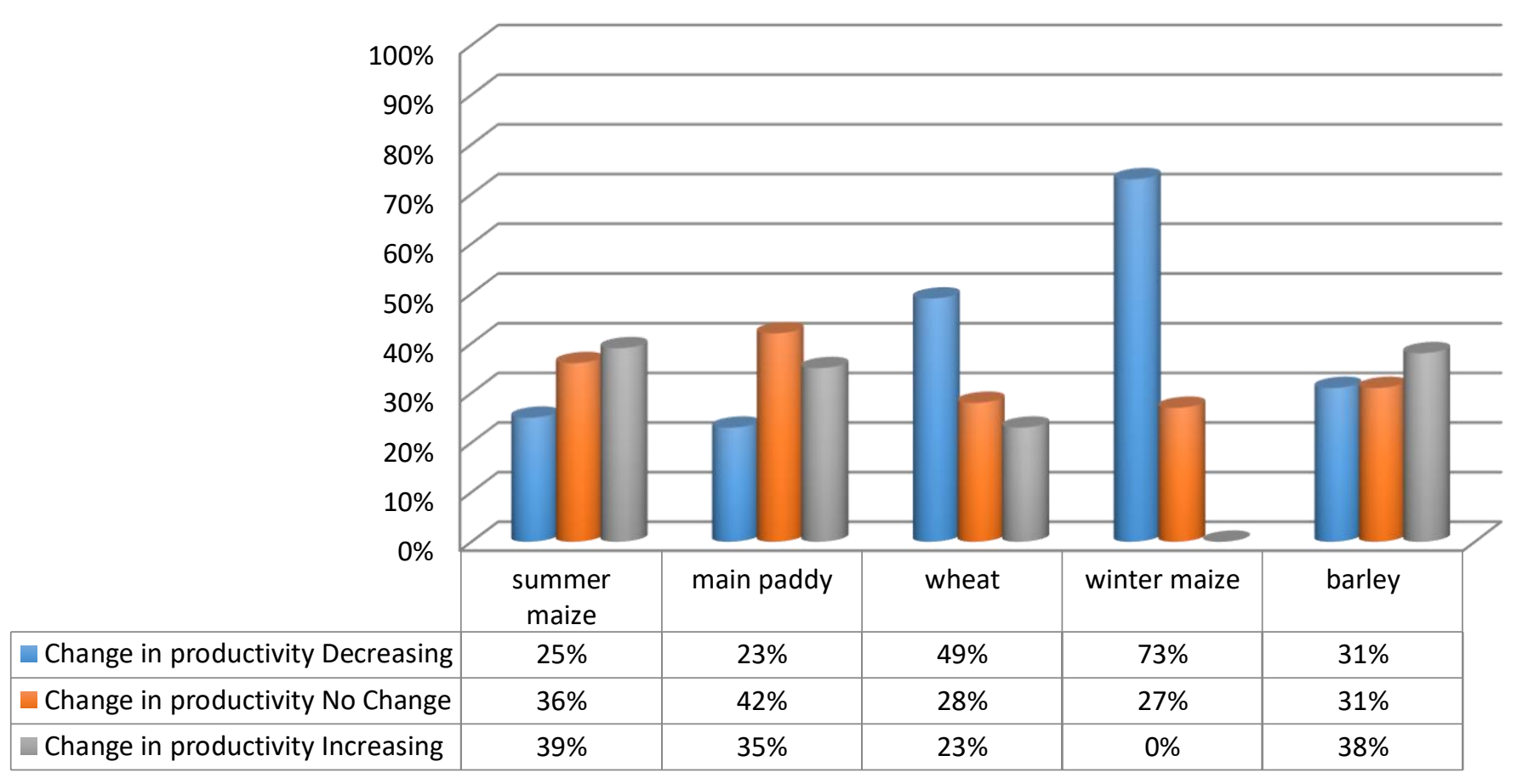

Figure 22 Perception of productivity change in staple crops in male-headed household in Baoshan

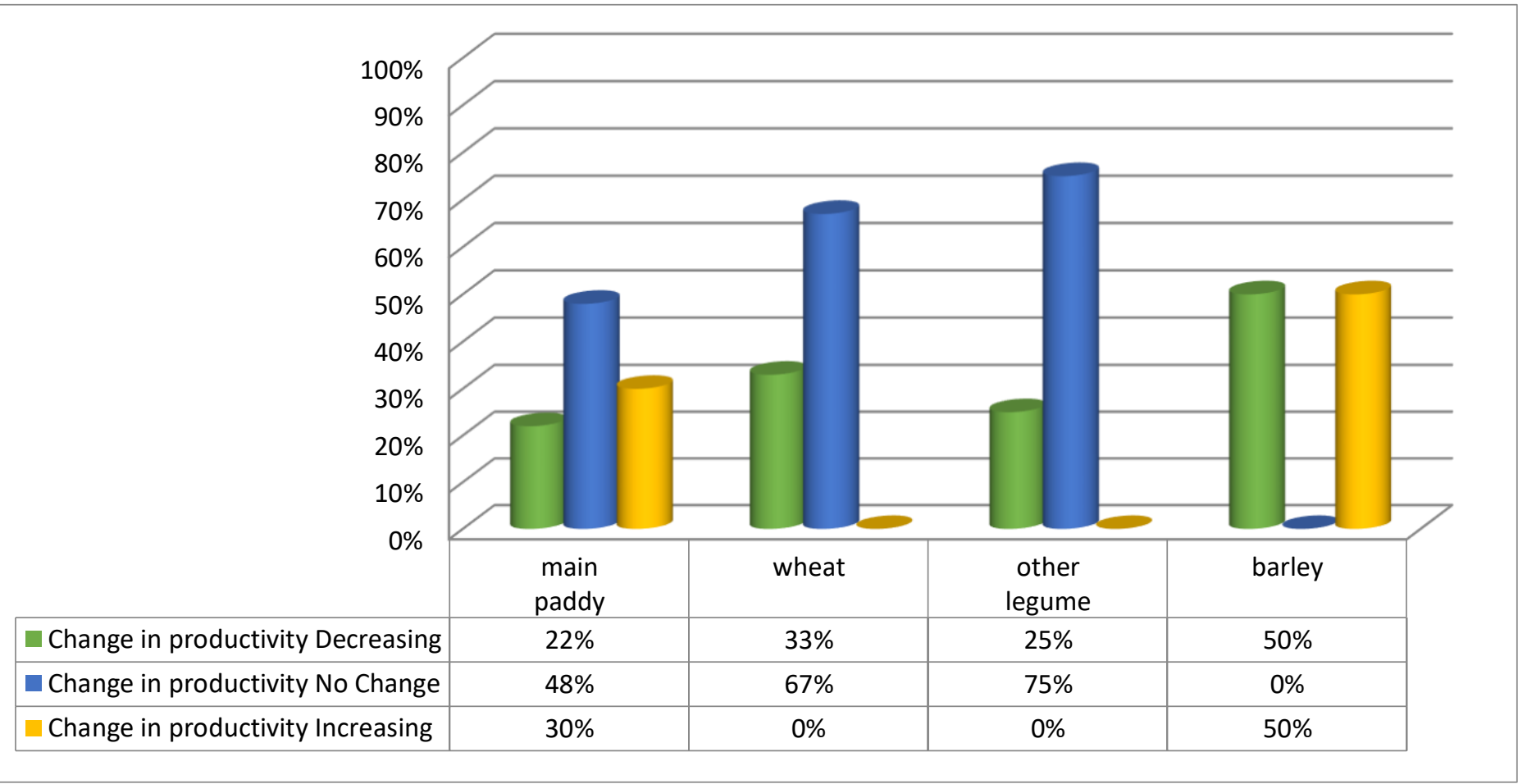

Figure 23 Perception of productivity change in staple crops in female-headed households in Baoshan 
Dali

In Dali, the majority of male-headed households reported a decrease in yields of barley and peas. In all other staple crop categories, the majority of male-headed households reported no change. The majority of female-headed households reported no change in yield for any staple crops.

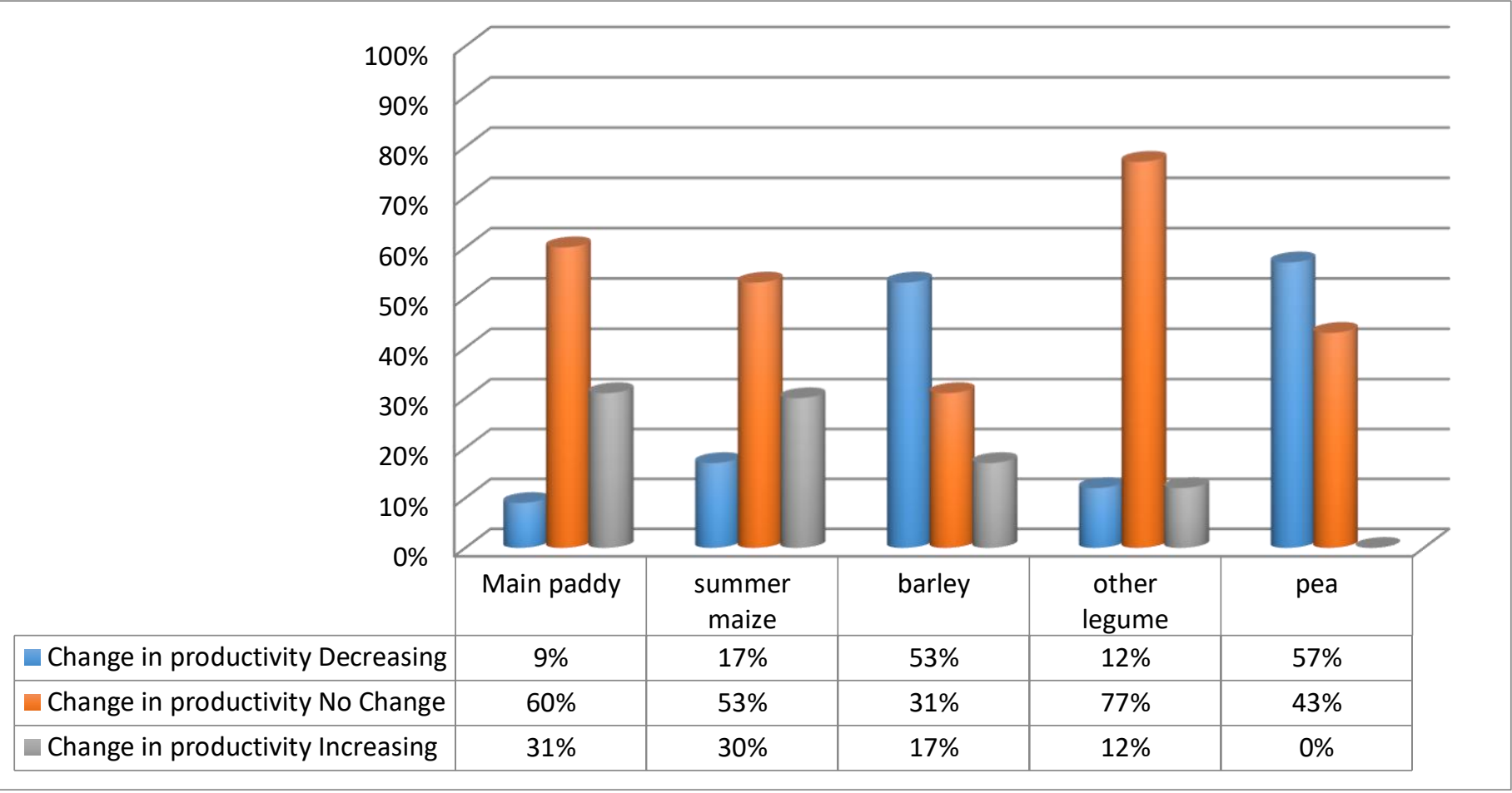

Figure 24 Perception of productivity change in male-headed households in Dali 


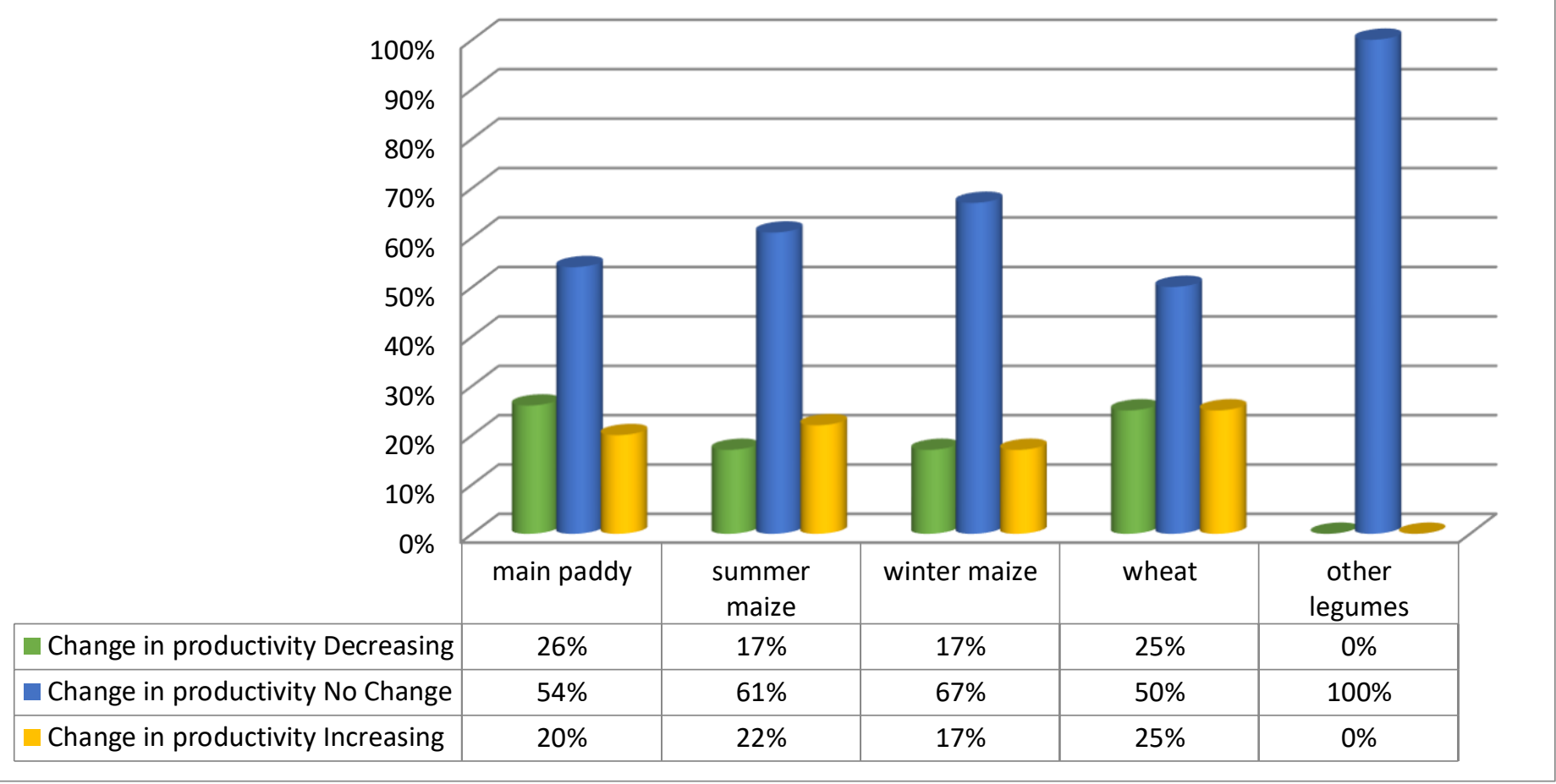

Figure 25 Perception of productivity change in staple crops in female-headed households in Dali 


\section{Diqing}

In Diqing prefecture, female-headed households tended to produce more of all crops than did male-headed households, except for summer maize. Fifty-seven percent of maleheaded households and $50 \%$ of female-headed households reported an increase in barley yield. Sixty-three percent of female-headed households reported a decrease in winter maize yields. Fifty-three percent of male-headed households described an increase in wheat yields.

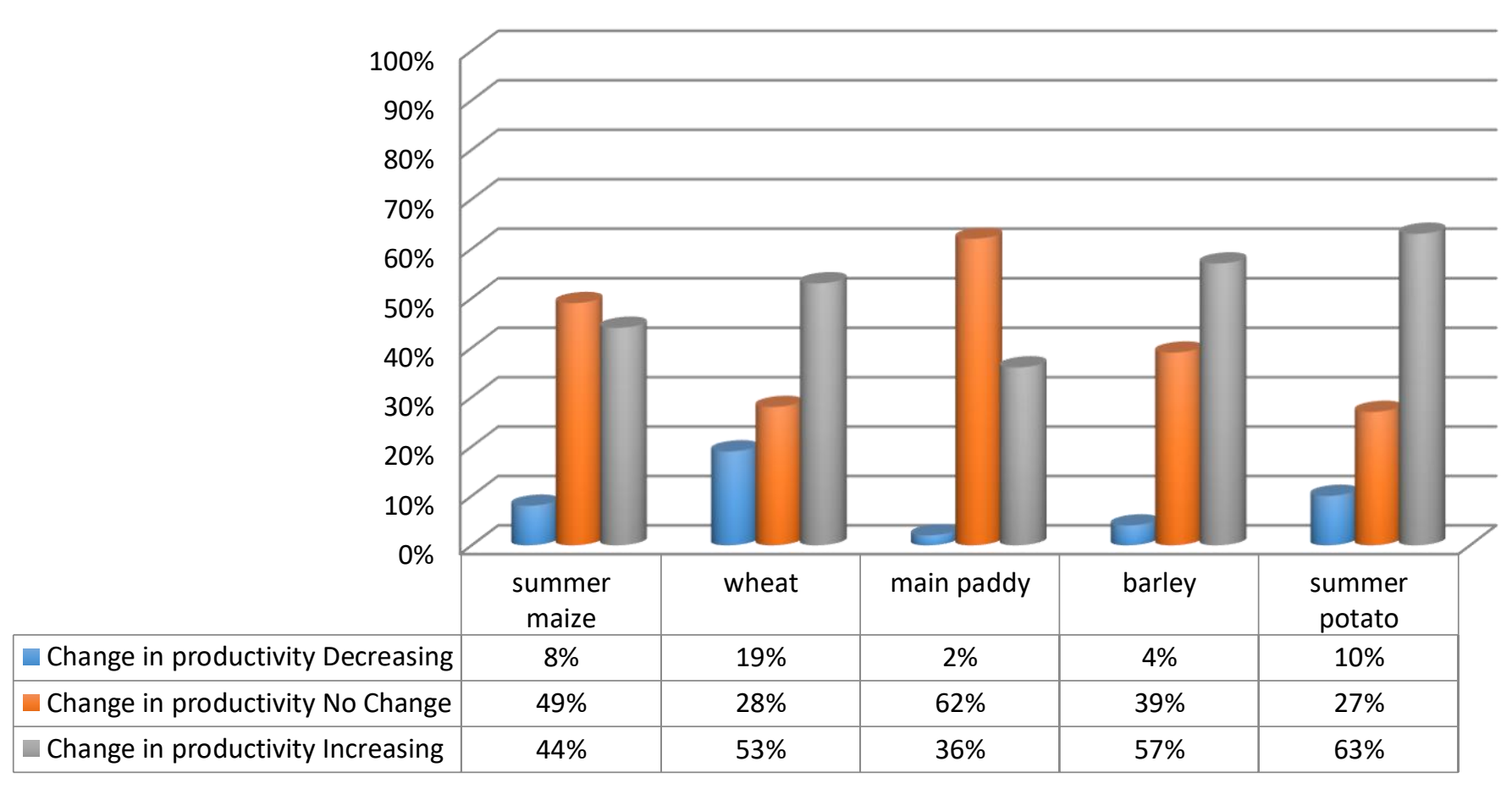

Figure 26 Perception of productivity change in male-headed households in Diqing 


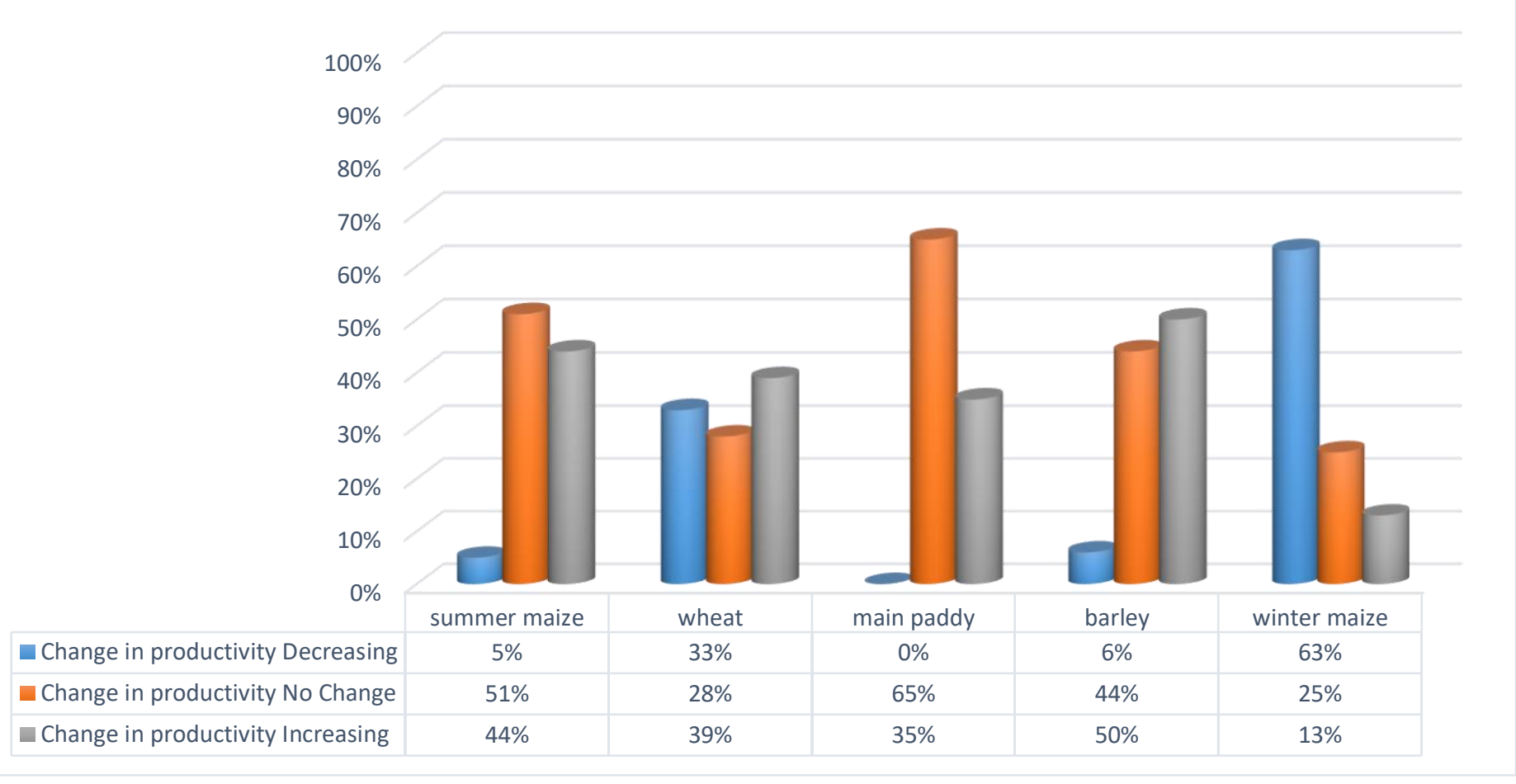

Figure 27 Perception of productivity change in female-headed households in Diqing

\section{Nujiang}

Based on the survey responses in the other prefectures, male-headed households

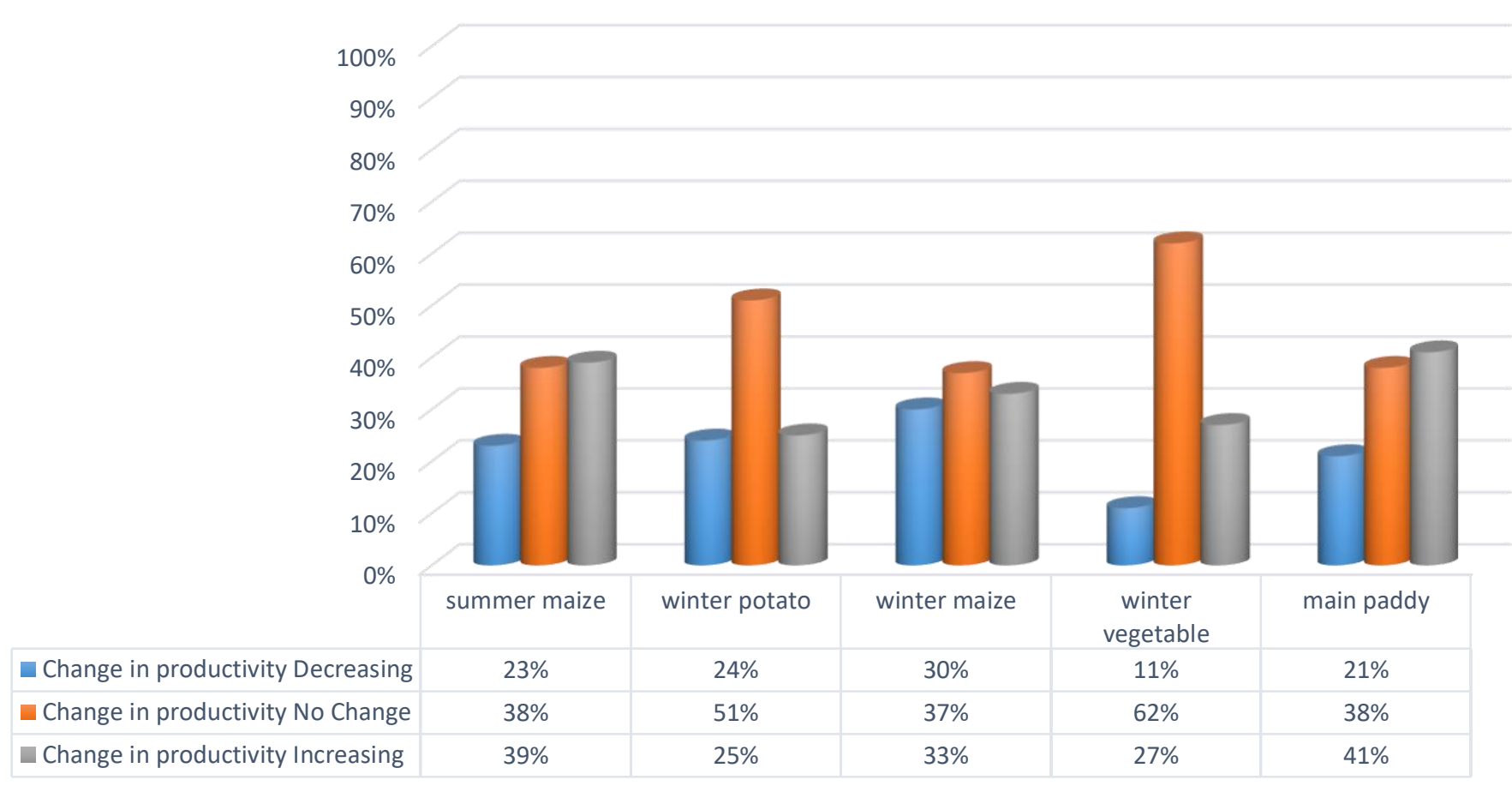

produced more staple crops than female-headed households, especially summer maize and winter maize. The same pattern was reported in Nujiang. Over $50 \%$ of both male and female-headed households reported no change in winter potato yield. Sixty-two percent of male-headed households described no change in winter vegetables yield, while $50 \%$ of female-headed households reported an increase.

Figure 28 Perception of productivity change in staple crops of male-headed households in Nujiang 


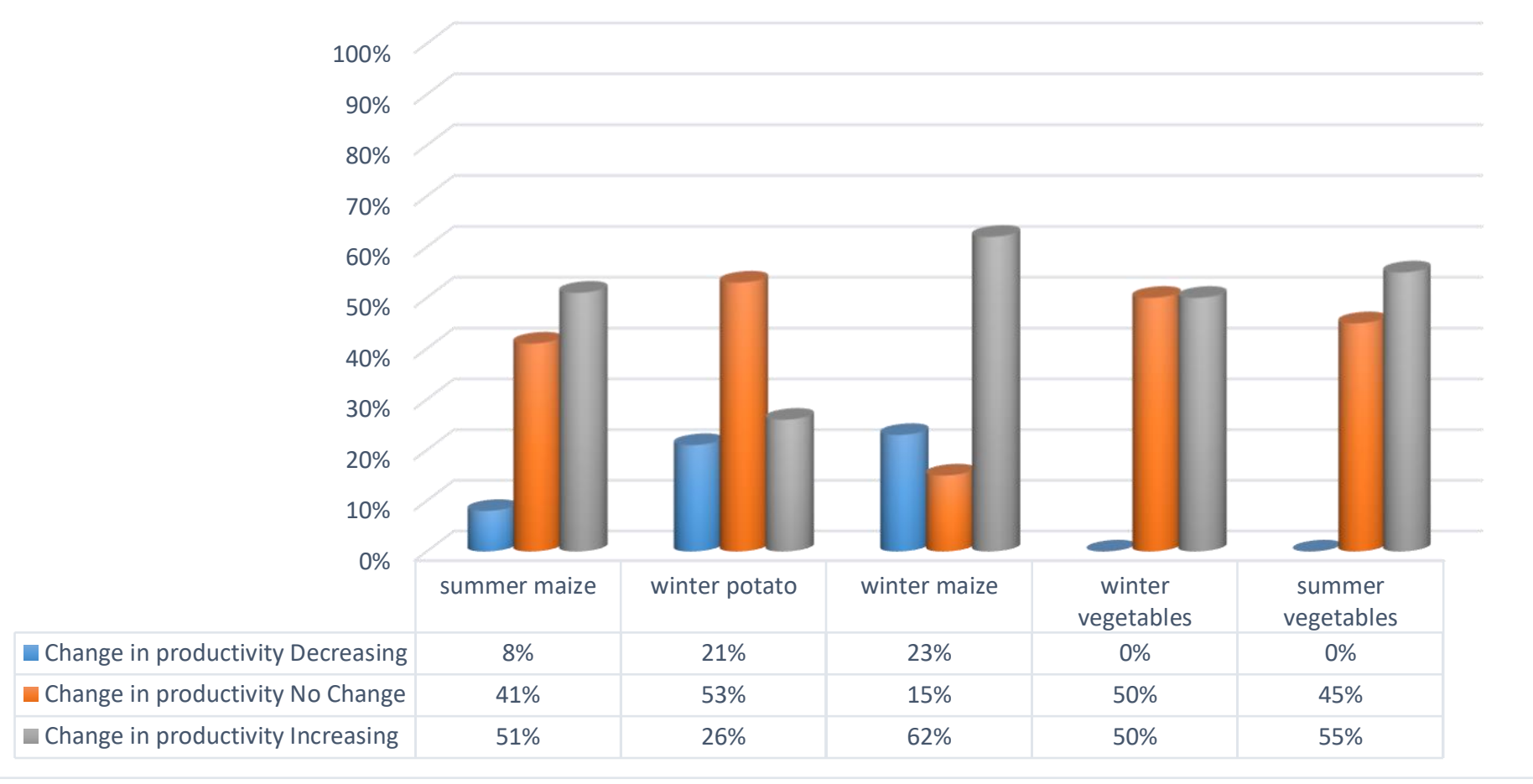

Figure 29 Perception of productivity change in staple crops of female-headed households in Nujiang

\subsection{Perceptions and strategies}

\subsubsection{Perceptions of climate change}

Perceptions of climate change varied greatly according to gender and geographical location. Generally, $83 \%$ of men and $78 \%$ of women reported having experienced some form of climate change over the last 10 years. Reports of climate change were most frequent in Baoshan, for both male-headed (95\%) and female-headed (90\%) households, while in Nujiang, where experience of climate change was least common, the rate dropped to $71 \%$ of male-headed households and $64 \%$ of female-headed households. 


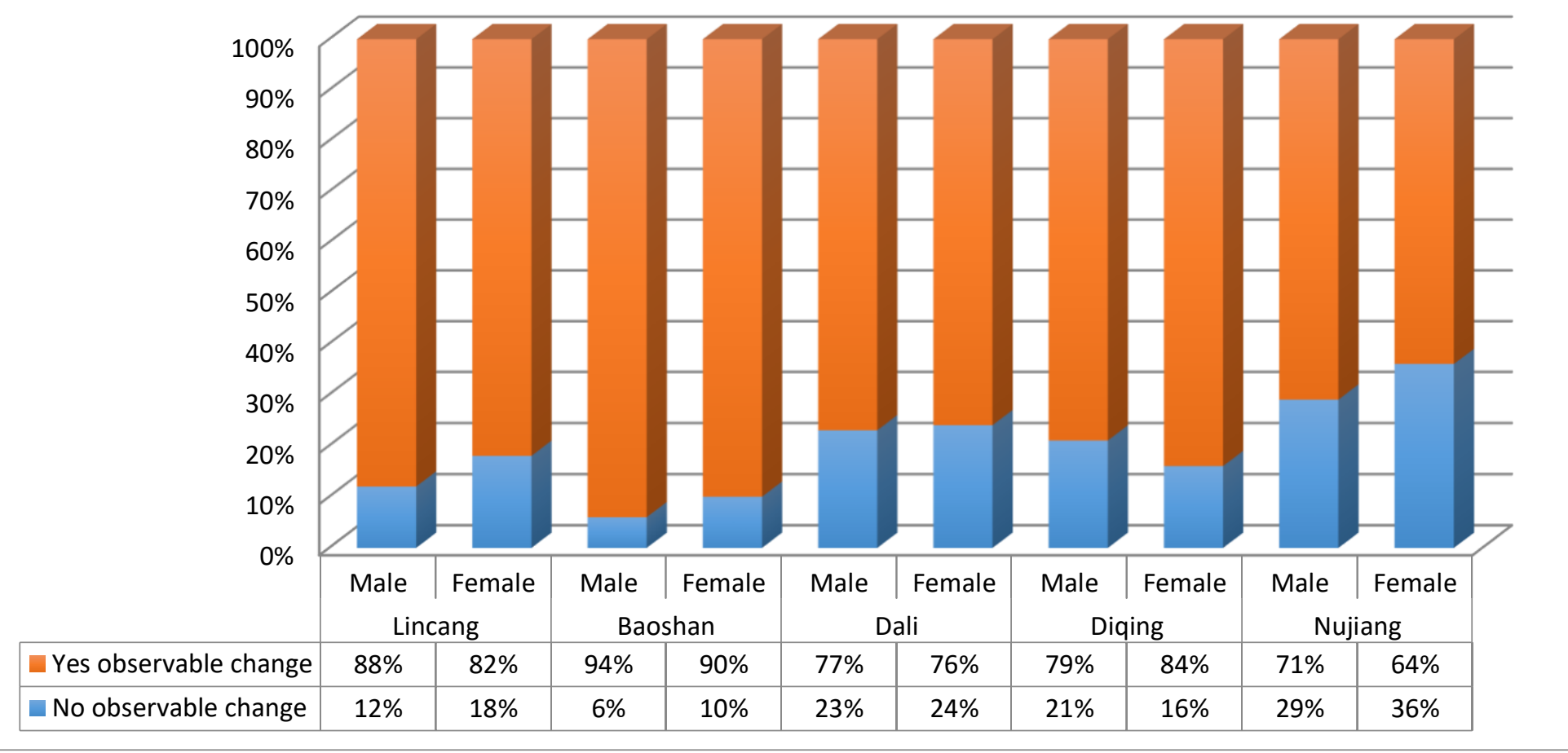

Figure 30 Perception of climate change

\section{Lincang}

In Lincang, $44 \%$ of men believe that there has been no change in cold season temperatures, while an equal percentage of men believed that there were observable changes, and that cold seasons have been less severe recently. The majority of female respondents in Lincang reported no change in the severity of recent cold seasons. Both male and female respondents believed that there had been no significant changes in precipitation.

\section{Baoshan}

Data from Baoshan showed significantly different perceptions of climate change. Over half of the respondents indicated that they observed warmer temperatures during the cold season; however, more men supported this claim than women. No significant difference was observed between men and women concerning changes in precipitation.

\section{Dali}

In Dali, $69 \%$ of men and $74 \%$ of women reported a decrease in annual precipitation, and over $56 \%$ believed it was due to a decrease in precipitation during the winter months. Over $30 \%$ of total respondents reported that precipitation had become unpredictable, but over half of women respondents reported no change in the rainy seasons.

\section{Diqing}

In Diqing, 79\% of total respondents reported changes in precipitation. Forty-one percent of both men and women respondents reported a decrease in annual precipitation. Around 
half of respondents overall stated that there was no observed decrease in rainy days or snowy days.

\section{Nujiang}

In Nujiang, $84 \%$ of female respondents believed there were changes in temperature; this was supported by $79 \%$ of male respondents. Around $41 \%$ of total respondents described a decrease in annual precipitation, while around a quarter of total respondents reported an increase in annual precipitation. Thirty-seven percent of total respondents reported unpredictable precipitation. There was no difference between genders in perceptions of temperature and precipitation.

\subsubsection{Adaptation Strategies}

\section{Identification of shocks and damages}

An important area of research for this study centers on vulnerability to shocks and adaptation strategies. It is not only important to identify these shocks and adaptation strategies, but also important to understand how gender and geographical location create additional risk factors and marginalization within specific communities. To accurately record shocks, survey respondents were asked to identify specific shocks that they experienced over the last 12 months. The question included 45 possible shocks that a household could experience and asked respondents to choose eight that their household had experienced, and to rate these in terms of severity. The severities of the identified shocks were recorded using a scale, with 1 representing the lowest severity and 5 signifying the highest.

\section{Lincang}

Male-headed households in Lincang identified family illness as the most severe shock with an average monetary cost of approximately 7173 RMB per household. Following illness, livestock disease was rated the second most severe shock, costing an average of 4200 RMB. In contrast, female-headed households identified livestock disease as the most severe shock, costing on average 7100 RMB per household, and family sickness ranked as the third in severity and the second as damage. In Lincang, female-headed households spend 2900 RMB more in mitigating livestock disease than male-headed households. Drought (impact of lower than average precipitation in a single year), extended droughts (impact of lower than average precipitation across multiple years, such as the drought of 2009 to 2012) and strong winds were also all listed as shocks experienced by both female and male-headed households. In total, male-headed households spent an average of 19515.17 RMB mitigating shocks, while female-headed households spent 18613.10 RMB. 


\begin{tabular}{|c|c|c|c|c|}
\hline \multirow{2}{*}{ Lincang } & \multicolumn{2}{|c|}{ Male headed HH } & \multicolumn{2}{|c|}{ Female headed HH } \\
\hline & Problems/Shocks & Severity/Damage & Problems & Severity/Damage \\
\hline \multirow{5}{*}{$\begin{array}{l}\text { Severity } \\
\text { of shocks } \\
\text { (top } 5 \text { ) }\end{array}$} & Family Sickness & 4.56 & Livestock Disease & 4.4 \\
\hline & Livestock Disease & 4.21 & Drought & 4.11 \\
\hline & Extended drought & 4.12 & Family Sickness & 4.1 \\
\hline & Drought & 4.1 & Extended drought & 4.07 \\
\hline & Strong Wind & 3.81 & Crop Pest & 4 \\
\hline \multirow{5}{*}{$\begin{array}{l}\text { Damage } \\
\text { caused } \\
\text { by shock } \\
\text { (top 5) }\end{array}$} & Family Sickness & 7173.28 & Livestock Disease & 7100 \\
\hline & Livestock Disease & 4196.87 & Family Sickness & 5025 \\
\hline & Drought & 3258.75 & Extended drought & 2728.52 \\
\hline & Extended drought & 2962.36 & Drought & 2077.77 \\
\hline & Strong Wind & 1923.99 & Strong Wind & 1681.81 \\
\hline
\end{tabular}

\section{Baoshan}

Men in Baoshan estimated the damage for all types of shock at a higher rate than did women. The data collected in Baoshan indicates that family sickness is the most severe shock in both severity and damage for all households surveyed. The severity and damage value reported by both male and female-headed households were similar, but on average male-headed households spent 220 RMB more than female-headed households in order to mitigate family illness. Strong winds were ranked second in severity for male-headed households while strong winds were ranked third for female-headed households. All households listed drought and extended droughts as significant shocks. Drought severity was listed similarly in both male and female-headed households, but with variations in rank and value. Male household heads also ascribed a higher damage value to drought than did female household heads.

Table 19 Severity of shocks and damage in Baoshan

\begin{tabular}{|c|c|c|c|c|}
\hline \multirow{2}{*}{ Baoshan } & \multicolumn{2}{|c|}{ Male headed HH } & \multicolumn{2}{|c|}{ Female headed $\mathrm{H}$} \\
\hline & Problems/Shocks & Severity/Damage & Problems & Severity/Damage \\
\hline \multirow{5}{*}{$\begin{array}{l}\text { Severity of } \\
\text { shock (top 5) }\end{array}$} & Family Sickness & 4.4 & Family Sickness & 4.42 \\
\hline & Strong Wind & 4.15 & Extended drought & 3.92 \\
\hline & Drought & 3.84 & Strong Wind & 3.83 \\
\hline & Extended drought & 3.78 & Drought & 3.71 \\
\hline & Erratic Rainfall & 3.71 & Erratic Rainfall & 3.5 \\
\hline \multirow{5}{*}{$\begin{array}{l}\text { Damage } \\
\text { caused by } \\
\text { shock (top 5) }\end{array}$} & Family Sickness & 6119.89 & Family Sickness & 5900 \\
\hline & Strong Wind & 3011 & Drought & 1971.42 \\
\hline & Drought & 2536.16 & Strong Wind & 1933.333 \\
\hline & Extended drought & 2053.85 & Extended drought & 1346.15 \\
\hline & Erratic Rainfall & 2015.38 & Erratic Rainfall & 1200 \\
\hline
\end{tabular}


In Dali, unlike in Baoshan and Lincang, debt, labour shortage, and hail were listed as significant shocks. Debt was ranked the first in severity by male-headed households, with average damages estimated at 29416 RMB. However, debt was not listed as a major shock by female-headed households. Male-headed households also listed hail as a major shock, incurring damage of $2890 \mathrm{RMB}$; however, female-headed households did not identify this as a shock. In female-headed households, family sickness was listed as the most severe shock, with average damages costing 14907 RMB. Hail was ranked second in severity by male-headed households, but was said to be only the fifth most damaging in terms of costs, at an average of 10617 RMB. Female-headed households also listed crop pests as a major problem in the last year while male-headed households did not list it as a problem. Based on these responses, variation in shocks was more closely tied to gender in Dali than in Baoshan and Lincang.

Table 20 Severity of shocks and damage in Dali

\begin{tabular}{|c|c|c|c|c|}
\hline \multirow{2}{*}{ Dali } & \multicolumn{2}{|c|}{ Male headed HH } & \multicolumn{2}{|c|}{ Female headed HH } \\
\hline & Problems/Shocks & Severity/Damage & Problems & Severity/Damage \\
\hline \multirow{5}{*}{$\begin{array}{l}\text { Severity } \\
\text { of shock } \\
\text { (top 5) }\end{array}$} & Debt & 4.75 & Family Sickness & 4.07 \\
\hline & Family Sickness & 4.11 & Livestock Disease & 3.62 \\
\hline & Livestock Disease & 3.83 & Drought & 3.4 \\
\hline & Drought & 3.72 & labour Shortage & 2.66 \\
\hline & Hail & 3.63 & Crop Pest & 2.6 \\
\hline \multirow{5}{*}{$\begin{array}{l}\text { Damage } \\
\text { caused } \\
\text { by shock } \\
\text { (top 5) }\end{array}$} & Debt & 29416.79 & Family Sickness & 14907.69 \\
\hline & Family Sickness & 10617.93 & Labour Shortage & 4666.66 \\
\hline & Livestock Disease & 6388.19 & Livestock Disease & 2537.5 \\
\hline & Drought & 3314.5 & Drought & 1790 \\
\hline & Hail & 2890 & Crop Pest & 640 \\
\hline
\end{tabular}

\section{Diqing}

Similarly, in Diqing, family illness was said to be a major and costly shock. Both male and female-headed households ranked this problem as being the most severe, but the estimated damage varied widely. Female-headed households estimated the average loss as being $10500 \mathrm{RMB}$ higher than did male-headed households. Landslide/erosion was identified in this prefecture as a major problem by all households, but not in other regions. On average, male-headed households spent 2131.82 RMB more mitigating landslides/erosion than female-headed households, even though female-headed households ranked this problem as being of a higher severity. Livestock disease, commonly listed in other areas, was also listed as a major concern for all households. However, as with other areas, the average estimation given by male-headed households was less than that given by female-headed households - in this case, 1281.77 RMB less. 
Table 21 Severity of shocks and damage in Diqing

\begin{tabular}{|c|c|c|c|c|}
\hline \multirow{2}{*}{ Diqing } & \multicolumn{2}{|c|}{ Male headed HH } & \multicolumn{2}{|c|}{ Female headed HH } \\
\hline & Problems/Shocks & Severity/Damage & Problems & Severity/Damage \\
\hline \multirow{5}{*}{$\begin{array}{l}\text { Severity of } \\
\text { shock (top 5) }\end{array}$} & Family Sickness & 4.09 & Family Sickness & 4.07 \\
\hline & Livestock Disease & 3.79 & Landslide/erosion & 3.81 \\
\hline & Landslide/erosion & 3.68 & Livestock Disease & 3.58 \\
\hline & Crop Pest & 3.45 & Crop Pest & 3.55 \\
\hline & Extended drought & 3.4 & Drought & 3.38 \\
\hline \multirow{5}{*}{$\begin{array}{l}\text { Damage } \\
\text { caused by } \\
\text { shock (top 5) }\end{array}$} & Family Sickness & 10094.38 & Family Sickness & 20623.81 \\
\hline & Extended drought & 6168.18 & Landslide/erosion & 2745.45 \\
\hline & Landslide/erosion & 4877.27 & Livestock Disease & 2383.33 \\
\hline & Livestock Disease & 3300 & Drought & 2018.23 \\
\hline & Drought & 1939.88 & Crop Pest & 1907.5 \\
\hline
\end{tabular}

\section{Nujiang}

As in all of the other prefectures, family sickness was ranked as a major shock, with maleheaded households estimating an average cost of 8024 RMB. Impact of rodents on food resources was rated at the same level of severity, but female-headed households estimated that it cost almost double the amount spent on family illness. However, femaleheaded households did rate family illness as being of high severity, and estimated its cost at roughly the same amount as did male-headed households.

Table 22 Severity of shocks and damage in Nujiang

\begin{tabular}{|c|c|c|c|c|}
\hline \multirow{2}{*}{ Nujiang } & \multicolumn{2}{|c|}{ Male headed HH } & \multicolumn{2}{|c|}{ Female headed HH } \\
\hline & Problems/Shocks & Severity/Damage & Problems & Severity/Damage \\
\hline \multirow{5}{*}{$\begin{array}{l}\text { Severity of } \\
\text { shock (top 5) }\end{array}$} & Family Sickness & 3.95 & Rodent impact & 4 \\
\hline & Livestock Disease & 3.79 & Family Sickness & 3.75 \\
\hline & Strong Wind & 3.68 & Livestock Disease & 3.48 \\
\hline & Erratic Rainfall & 3.68 & Strong Wind & 3.2 \\
\hline & Drought & 3.28 & Erratic Rainfall & 3 \\
\hline \multirow{5}{*}{$\begin{array}{l}\text { Damage } \\
\text { caused by } \\
\text { shock (top 5) }\end{array}$} & Family Sickness & 8024.87 & Rodent impact & 14687.5 \\
\hline & Livestock Disease & 3936.16 & Family Sickness & 8322.11 \\
\hline & Strong Wind & 1424.13 & Livestock Disease & 3001.85 \\
\hline & Drought & 1396.87 & Strong Wind & 1172 \\
\hline & Extended drought & 1394.73 & Drought & 1121.42 \\
\hline
\end{tabular}

Response strategies to shocks and damages

When shocks affect specific households or even communities, there are specific strategies that heads of households will follow. These strategies often depend upon social networks that may not be available to all. Asking for help from one's extended family is often seen as the first channel for assistance, followed by friends, and finally the wider community. Restricting adult consumption was also widely identified as a coping strategy. This could 
be especially problematic for women because entitlements such as an adequate amount of food per day are often eroded in response to household shocks. This could leave women more vulnerable to disease and lower their overall ability to take part in labour, thus reducing household income. Household adaptation strategies varied greatly in relation to gender and geography.

\section{Lincang}

In Lincang, 33\% of male-headed households stated that they would borrow money from relatives in order to mitigate shocks. Thirty percent said that they would encourage their family members to take work as labourers, and around $24 \%$ stated they would seek shelter in other communities. Thirty-six percent of female-headed households in Lincang would borrow money from their relatives. Twenty-three percent would migrate, and $20 \%$ would use savings to buy food.

\section{Baoshan}

Households in Baoshan had the same coping strategies, regardless of gender. Thirty-two percent of male-headed households and 31\% of female-headed households would borrow money from relatives as the first option, and would work outside of the village as a second option. Male and female-headed households diverged on the third coping channel: $22 \%$ of male-headed households would seek wage employment in the same community, while $20 \%$ of female-headed households would restrict the consumption of adults.

Dali

The coping strategies chosen in Dali were similar to those in Lincang and Baoshan. Borrowing money from relatives was also the first option for both male and femaleheaded households. Eighteen percent of male-headed households would borrow from a bank, while $13 \%$ of female-headed households would migrate. Seventeen percent of male-headed households would spend savings on food, while $9 \%$ of female-headed households would borrow money from a bank.

\section{Diqing}

In Diqing, $19 \%$ of male-headed households would attempt to restrict adult consumption, $16 \%$ would attempt to make savings on food, and $11 \%$ would sell farmland. Femaleheaded households chose the same strategies as their male counterparts, but with variations in percentages.

\section{Nujiang}

In Nujiang, significant variance existed between male and female-headed households. Thirty percent of male-headed households would choose to first restrict adult consumption, then borrow money from relatives, and then restrict food consumption. Twenty-four percent of female-headed households would borrow money from relatives, and would then save money on food. 


\subsection{Gender disaggregated vulnerability across Prefectures}

Based on the Livelihood Vulnerability Index (LVI), we analyzed gender vulnerability across the five prefectures through the following components: social demographic, livelihoods, health, social networks, food, water, natural disaster and climate variability. Each indicator is made up of several sub-indicators measured on several different scales as mentioned in the methodology section. We followed the LVI analysis that Hahn et al. (2008) pioneered in Mozambique. Our analysis reveals that in general, female-headed households were vulnerable in three major areas: social-demographic factors, health and access to water. Male-headed households were vulnerable in four major areas: livelihoods, community networking, natural disasters and climate change. 
Table 23 LVI Components of gender across five prefectures

\begin{tabular}{|c|c|c|c|c|c|c|c|c|c|c|c|c|c|}
\hline \multirow{2}{*}{$\begin{array}{l}\text { Major } \\
\text { components }\end{array}$} & \multirow{2}{*}{ Sub-components } & \multicolumn{2}{|c|}{ Lincang } & \multicolumn{2}{|c|}{ Baoshan } & \multicolumn{2}{|c|}{ Dali } & \multicolumn{2}{|c|}{ Diqing } & \multicolumn{2}{|c|}{ Nujiang } & \multirow[b]{2}{*}{ Max } & \multirow[b]{2}{*}{ Min } \\
\hline & & Male & Female & Male & Female & Male & Female & Male & Female & Male & Female & & \\
\hline \multirow{3}{*}{$\begin{array}{l}\text { Social- } \\
\text { demographic }\end{array}$} & Dependency Ratio & 0.298 & 0.369 & 0.398 & 0.416 & 0.341 & 0.269 & 0.305 & 0.274 & 0.192 & 0.225 & 1 & 0 \\
\hline & $\begin{array}{l}\text { Percentage of household heads who did not attend } \\
\text { school }\end{array}$ & 10.77 & 29.03 & 20 & 5.89 & 4.7 & 13.63 & 6.36 & 14.87 & 24 & 37.63 & 100 & 0 \\
\hline & Average age of household head & 45.07 & 43.1 & 47.68 & 42.16 & 47.34 & 43.51 & 43.83 & 43.52 & 43.47 & 40.69 & 100 & 20 \\
\hline \multirow{3}{*}{ Livelihoods } & $\begin{array}{l}\text { Percentage of households with family members not } \\
\text { working in their own community }\end{array}$ & 24.31 & 27.93 & 28.52 & 27.21 & 16.7 & 16.7 & 15.28 & 19.67 & 12.76 & 11.28 & 100 & 0 \\
\hline & $\begin{array}{l}\text { Percentage of households entirely dependent on } \\
\text { agriculture as income source }\end{array}$ & 31.67 & 27.05 & 27.91 & 20.08 & 17.23 & 9.04 & 21.8 & 29.56 & 12.48 & 19.16 & 100 & 0 \\
\hline & Average Agricultural Livelihood Diversification Index & 0.19 & 0.24 & 0.24 & 0.22 & 0.41 & 0.3 & 0.23 & 0.28 & 0.262 & 0.287 & 1 & 0.16 \\
\hline \multirow{3}{*}{ Health } & $\begin{array}{l}\text { Percentage of household health affected seriously by } \\
\text { natural disasters }\end{array}$ & 16.42 & 26.8 & 29.48 & 20.15 & 15.57 & 24.92 & 26.9 & 38.51 & 26.7 & 23.34 & 100 & 0 \\
\hline & Affordability of treatment for serious illness or injury & 3.58 & 3.16 & 3.83 & 3.51 & 4.54 & 4.6 & 4.75 & 4.85 & 4.04 & 4.23 & 6 & 1 \\
\hline & Frequency of serious illness & 1.81 & 2.14 & 1.73 & 1.77 & 1.71 & 1.86 & 1.71 & 1.81 & 2.22 & 2.09 & 7 & 1 \\
\hline \multirow{4}{*}{ Social Networks } & Help Seeking Channel index & 0.83 & 0.922 & 0.822 & 0.688 & 0.87 & 0.8 & 0.77 & 0.655 & 0.733 & 0.811 & 1 & 0.1 \\
\hline & Influence on local community decision-making & 2.8 & 2.51 & 2.72 & 2.6 & 2.81 & 2.48 & 3.24 & 3.2 & 2.91 & 2.9 & 5 & 1 \\
\hline & Access to credit & 3.26 & 3.41 & 3.46 & 3.37 & 3.5 & 3.48 & 3.5 & 3.6 & 3.39 & 3.28 & 5 & 1 \\
\hline & $\begin{array}{l}\text { Percentage of households participating in different } \\
\text { organizations }\end{array}$ & 7.63 & 2.72 & 6.09 & 7.25 & 13.78 & 14.5 & 54.81 & 58.91 & 17.63 & 16.62 & 100 & 0 \\
\hline \multirow{2}{*}{ Food } & Crop Diversity Index & 0.24 & 0.19 & 0.22 & 0.31 & 0.36 & 0.33 & 0.29 & 0.32 & 0.26 & 0.29 & 1 & 0.16 \\
\hline & Percentage of households which do not save seeds & 96.12 & 93.54 & 97.75 & 100 & 80.88 & 75.75 & 91.19 & 87.6 & 84.61 & 77.41 & 100 & 0 \\
\hline \multirow{2}{*}{ Water } & Affordability of frequently purchasing water & 1.88 & 3.09 & 2.3 & 3.51 & 2.76 & 3.12 & 1.09 & 1.73 & 2.25 & 1.86 & 5 & 1 \\
\hline & Water Quality & 3.94 & 3.71 & 3.68 & 3.45 & 3.86 & 3.83 & 4.03 & 4.09 & 4.01 & 3.92 & 5 & 1 \\
\hline \multirow{3}{*}{$\begin{array}{l}\text { Natural } \\
\text { disasters and } \\
\text { climate } \\
\text { variability }\end{array}$} & $\begin{array}{l}\text { Percentage of households reporting temperature } \\
\text { changes in the past } 20 \text { years }\end{array}$ & 86.18 & 83.87 & 92.97 & 91.42 & 77.94 & 68.18 & 80.63 & 83.47 & 69.23 & 61.29 & 100 & 0 \\
\hline & $\begin{array}{l}\text { Percentage of households reporting precipitation } \\
\text { changes in the past } 20 \text { years }\end{array}$ & 91.98 & 87.09 & 94.66 & 85.71 & 91.76 & 87.87 & 79.22 & 80.16 & 78.26 & 76.34 & 100 & 0 \\
\hline & $\begin{array}{l}\text { Percentage of households reporting environmental } \\
\text { changes in the past } 20 \text { years }\end{array}$ & 75.69 & 64.51 & 67.13 & 65.71 & 62.64 & 69.69 & 70.42 & 78.51 & 68.34 & 44.08 & 100 & 0 \\
\hline
\end{tabular}


Table 24 Standardized LVI value of gender across five prefectures

\begin{tabular}{|c|c|c|c|c|c|c|c|c|c|c|c|}
\hline \multirow{2}{*}{$\begin{array}{l}\text { Major } \\
\text { components }\end{array}$} & \multirow{2}{*}{ Sub-components } & \multicolumn{2}{|c|}{ Lincang } & \multicolumn{2}{|c|}{ Baoshan } & \multicolumn{2}{|c|}{ Dali } & \multicolumn{2}{|c|}{ Diqing } & \multicolumn{2}{|c|}{ Nujiang } \\
\hline & & Male & Female & Male & Female & Male & Female & Male & Female & Male & Female \\
\hline \multirow{3}{*}{$\begin{array}{l}\text { Social- } \\
\text { demographic }\end{array}$} & Dependency Ratio & 0.298 & 0.369 & 0.398 & 0.416 & 0.341 & 0.269 & 0.305 & 0.274 & 0.192 & 0.225 \\
\hline & $\begin{array}{l}\text { Percentage of household heads who did not attend } \\
\text { school }\end{array}$ & 0.1 & 0.29 & 0.2 & 0.05 & 0.04 & 0.13 & 0.06 & 0.14 & 0.24 & 0.37 \\
\hline & Average age of household head & 0.313 & 0.288 & 0.346 & 0.277 & 0.341 & 0.294 & 0.297 & 0.294 & 0.293 & 0.258 \\
\hline \multirow{3}{*}{ Livelihoods } & $\begin{array}{l}\text { Percentage of households with family members not } \\
\text { working in their own community }\end{array}$ & 0.24 & 0.27 & 0.28 & 0.27 & 0.16 & 0.16 & 0.15 & 0.19 & 0.12 & 0.11 \\
\hline & $\begin{array}{l}\text { Percentage of households entirely dependent on } \\
\text { agriculture as income source }\end{array}$ & 0.31 & 0.27 & 0.27 & 0.2 & 0.17 & 0.09 & 0.21 & 0.29 & 0.12 & 0.19 \\
\hline & Average Agricultural Livelihood Diversification Index & 0.964 & 0.904 & 0.904 & 0.928 & 0.702 & 0.833 & 0.916 & 0.857 & 0.878 & 0.848 \\
\hline \multirow{3}{*}{ Health } & $\begin{array}{l}\text { Percentage of household health affected seriously } \\
\text { by natural disasters }\end{array}$ & 0.164 & 0.268 & 0.294 & 0.2 & 0.155 & 0.249 & 0.269 & 0.385 & 0.267 & 0.233 \\
\hline & $\begin{array}{l}\text { Affordability of treatment for serious illness or } \\
\text { injury }\end{array}$ & 0.484 & 0.568 & 0.434 & 0.498 & 0.292 & 0.28 & 0.25 & 0.23 & 0.392 & 0.354 \\
\hline & Frequency of serious illness & 0.135 & 0.19 & 0.121 & 0.128 & 0.118 & 0.143 & 0.118 & 0.136 & 0.236 & 0.182 \\
\hline \multirow{4}{*}{ Social Networks } & Help Seeking Channel index & 0.25 & 0.17 & 0.26 & 0.38 & 0.21 & 0.28 & 0.3 & 0.41 & 0.34 & 0.27 \\
\hline & Influence on local community decision-making & 0.83 & 0.922 & 0.822 & 0.688 & 0.87 & 0.8 & 0.77 & 0.655 & 0.733 & 0.811 \\
\hline & Access to credit & 0.55 & 0.62 & 0.57 & 0.6 & 0.547 & 0.63 & 0.44 & 0.45 & 0.402 & 0.405 \\
\hline & $\begin{array}{l}\text { Percentage of households participating in different } \\
\text { organizations }\end{array}$ & 0.924 & 0.973 & 0.94 & 0.928 & 0.863 & 0.855 & 0.452 & 0.411 & 0.824 & 0.833 \\
\hline \multirow{2}{*}{ Food } & Crop Diversity Index & 0.904 & 0.964 & 0.928 & 0.821 & 0.761 & 0.797 & 0.845 & 0.809 & 0.88 & 0.845 \\
\hline & Percentage of households which do not save seeds & 0.96 & 0.93 & 0.97 & 1 & 0.8 & 0.75 & 0.91 & 0.87 & 0.84 & 0.77 \\
\hline \multirow{2}{*}{ Water } & Affordability of frequently purchasing water & 0.78 & 0.477 & 0.675 & 0.372 & 0.56 & 0.47 & 0.977 & 0.817 & 0.687 & 0.785 \\
\hline & Water Quality & 0.265 & 0.322 & 0.33 & 0.38 & 0.285 & 0.292 & 0.242 & 0.227 & 0.247 & 0.27 \\
\hline \multirow{3}{*}{$\begin{array}{l}\text { Natural } \\
\text { disasters and } \\
\text { climate } \\
\text { variability }\end{array}$} & $\begin{array}{l}\text { Percentage of households reporting temperature } \\
\text { changes in the past } 20 \text { years }\end{array}$ & 0.86 & 0.83 & 0.92 & 0.91 & 0.77 & 0.68 & 0.8 & 0.83 & 0.69 & 0.61 \\
\hline & $\begin{array}{l}\text { Percentage of households reporting precipitation } \\
\text { changes in the past } 20 \text { years }\end{array}$ & 0.91 & 0.87 & 0.94 & 0.85 & 0.91 & 0.87 & 0.79 & 0.8 & 0.78 & 0.76 \\
\hline & $\begin{array}{l}\text { Percentage of households reporting environmental } \\
\text { changes in the past } 20 \text { years }\end{array}$ & 0.75 & 0.64 & 0.67 & 0.65 & 0.62 & 0.69 & 0.7 & 0.78 & 0.68 & 0.44 \\
\hline
\end{tabular}


Table 25 LVI value of each sub-components of gender across five prefectures

\begin{tabular}{|c|c|c|c|c|c|c|c|c|c|c|}
\hline & \multicolumn{2}{|c|}{ Lincang } & \multicolumn{2}{|c|}{ Baoshan } & \multicolumn{2}{|c|}{ Dali } & \multicolumn{2}{|c|}{ Diqing } & \multicolumn{2}{|c|}{ Nujiang } \\
\hline & Male & Female & Male & Female & Male & Female & Male & Female & Male & Female \\
\hline Social-demographic & 0.237 & 0.315 & 0.314 & 0.247 & 0.24 & 0.231 & 0.22 & 0.236 & 0.241 & 0.284 \\
\hline Livelihood & 0.504 & 0.481 & 0.484 & 0.466 & 0.344 & 0.361 & 0.425 & 0.445 & 0.372 & 0.382 \\
\hline Health & 0.261 & 0.342 & 0.283 & 0.275 & 0.188 & 0.224 & 0.212 & 0.25 & 0.298 & 0.256 \\
\hline Social Networks & 0.638 & 0.671 & 0.648 & 0.649 & 0.622 & 0.641 & 0.49 & 0.481 & 0.574 & 0.579 \\
\hline Food & 0.932 & 0.947 & 0.949 & 0.91 & 0.78 & 0.775 & 0.877 & 0.839 & 0.86 & 0.8 \\
\hline Water & 0.522 & 0.399 & 0.5 & 0.376 & 0.422 & 0.381 & 0.609 & 0.522 & 0.467 & 0.527 \\
\hline $\begin{array}{l}\text { Natural Disasters and } \\
\text { climate vulnerability }\end{array}$ & 0.84 & 0.78 & 0.843 & 0.803 & 0.766 & 0.746 & 0.763 & 0.803 & 0.715 & 0.603 \\
\hline LVI & 0.549 & 0.556 & 0.563 & 0.527 & 0.475 & 0.478 & 0.489 & 0.492 & 0.491 & 0.477 \\
\hline
\end{tabular}

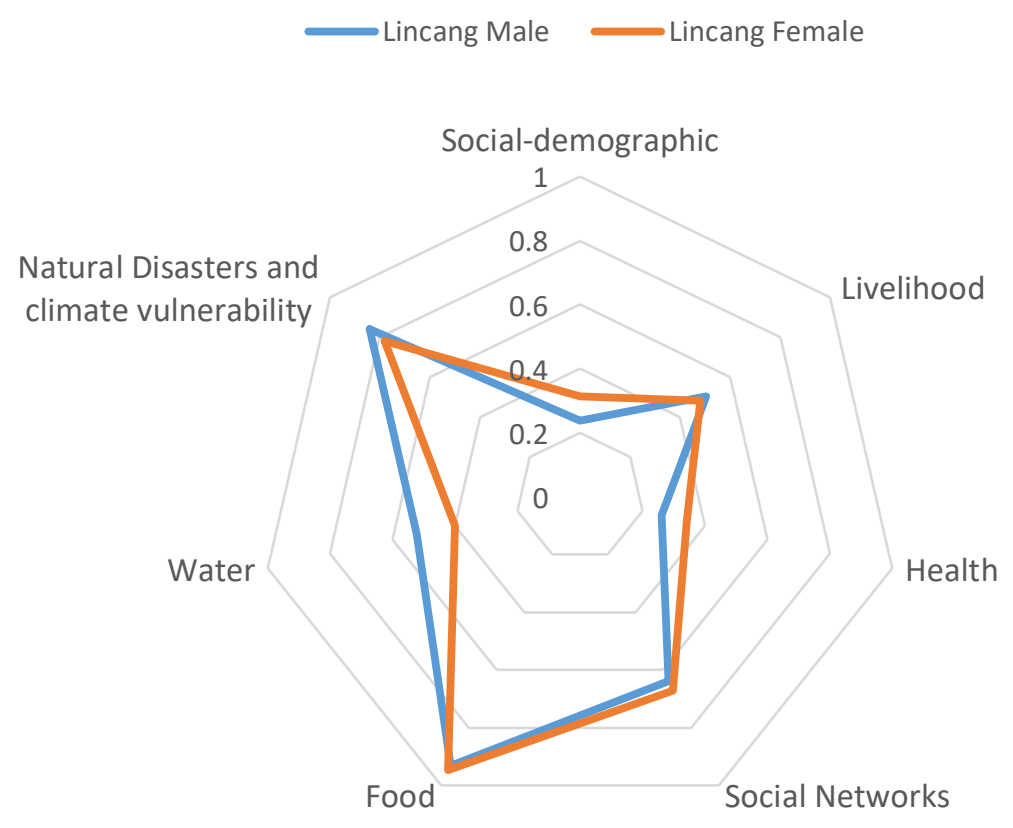

Figure 31 Livelihood vulnerability index in Lincang

In Lincang, female-headed households had a higher dependency ratio, a higher illiteracy rate, and planted less diverse crops than male-headed households. Femaleheaded households were more likely to be affected seriously by natural disasters; they experienced a higher frequency of serious illness; they had poorer water quality; less access to affordable healthcare; and more difficulty accessing loans and less influence on the local community's decisions. Generally, female-headed households were marginally more vulnerable than male-headed households, and experienced less 
exposure to climate change (see figure 4 for major components corresponding to Adaptive Capacity, Sensitivity, and Exposure).

Male-headed households were more vulnerable as measured by the Average Agricultural Livelihood Diversification Index. Male-headed households reported that purchasing water was unaffordable, and also were less likely to say that they had access to channels which might help them get assistance. Male-headed households were more adaptive and marginally less sensitive to climate change. Male and femalehouseholds had very similar LVI_IPCC scores (See Tables 25 and 26).

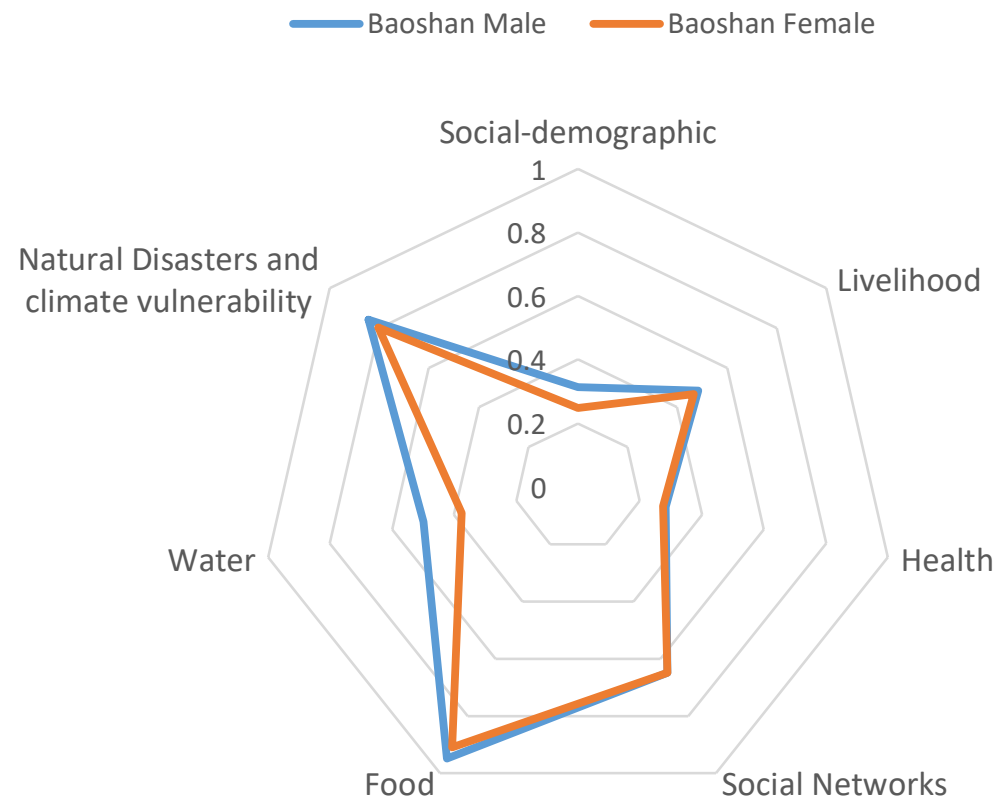

Figure 32 Livelihood vulnerability index in Baoshan

In Baoshan, female-headed households reported less access to affordable healthcare and help-seeking channels than did male-headed households, and overall femaleheaded households experienced poorer water quality. Female-headed households were more adaptive and were less sensitive and less exposed to climate change. Overall, female-headed households had a significantly lower LVI_IPCC score.

Male-headed households displayed higher illiteracy rates and had an older average age of household head. They were more likely to say that purchasing water was unaffordable, and were more vulnerable because many depended solely on agriculture as a source of income and were therefore, more likely to be affected seriously by natural disasters. Generally, male-headed households reported higher overall vulnerability. 


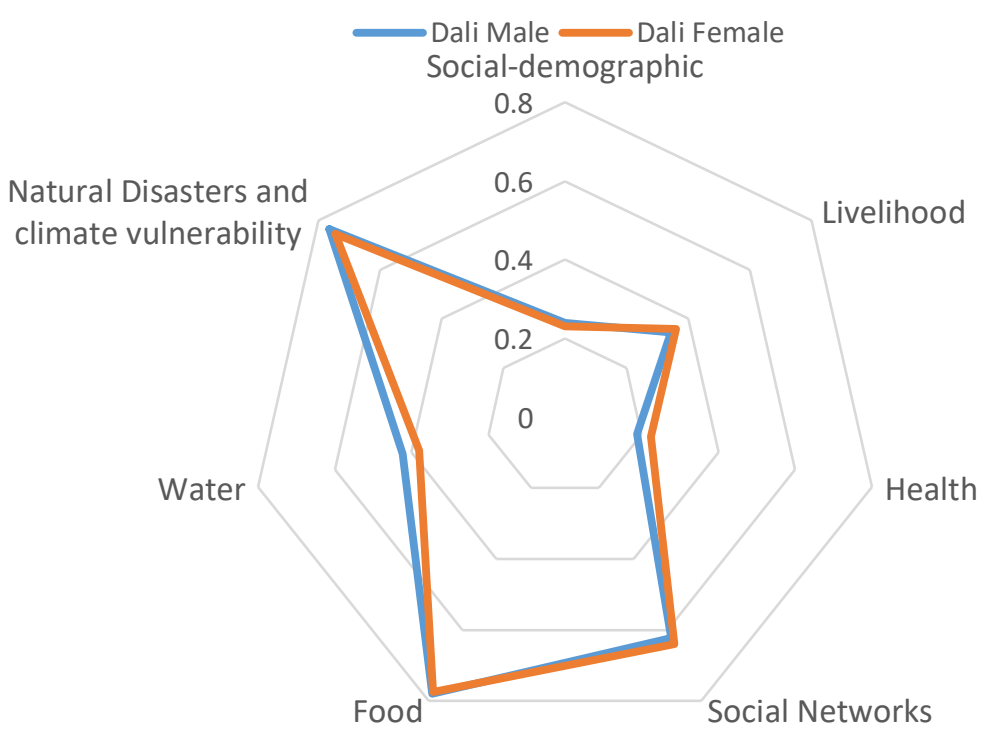

Figure 33 Livelihood vulnerability index in Dali

In Dali, female-headed households were more likely to be seriously affected by natural disasters, had more difficulty accessing loans and help seeking channels, and experienced poorer water quality. Generally, male and female-households experienced similar vulnerability and rates of sensitivity, but female-headed households experienced less exposure to climate change.

Male-headed households reported a higher dependency ratio, an older average age of household head, and more households that relied on agriculture as their sole source of income. Male-headed households had less influence on the local community's decisions. Male-headed households reported that purchasing water was unaffordable. Male-headed households had slightly more adaptive capacity and had a slightly better LVI_IPCC score. 


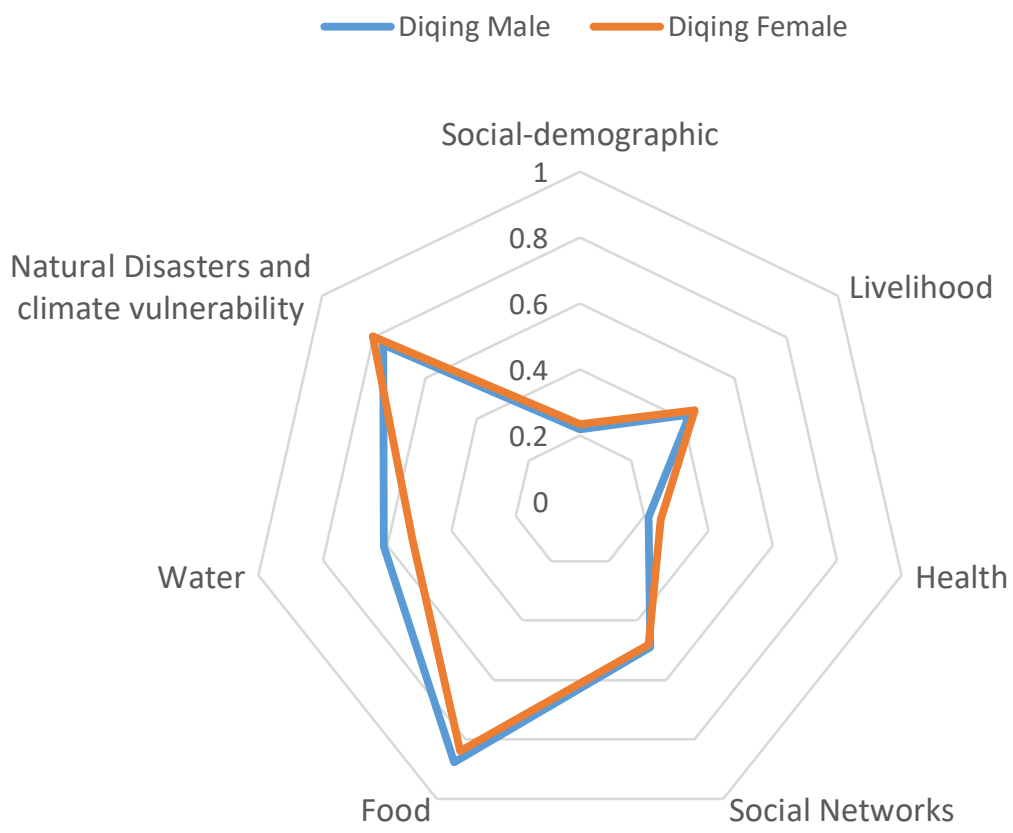

Figure 34 Livelihood vulnerability index in Diqing

In Diqing, female-headed households were more likely to depend on agriculture as their sole source of income, had less access to help-seeking channels and were more likely to be affected seriously by natural disasters. Overall, if all indicators are taken into account, female-headed households are less sensitive to climate change.

Male-headed households tend to have higher dependency ratios, were more vulnerable in terms of the Average Agricultural Livelihood Diversification Index, and had less influence on the local community. They also reported that purchasing water was unaffordable and experienced poorer water quality. Male-headed households had more adaptive capacity and experienced less exposure to climate change. Overall, male and female-headed households in Diqing had the same LVI_IPCC score. 


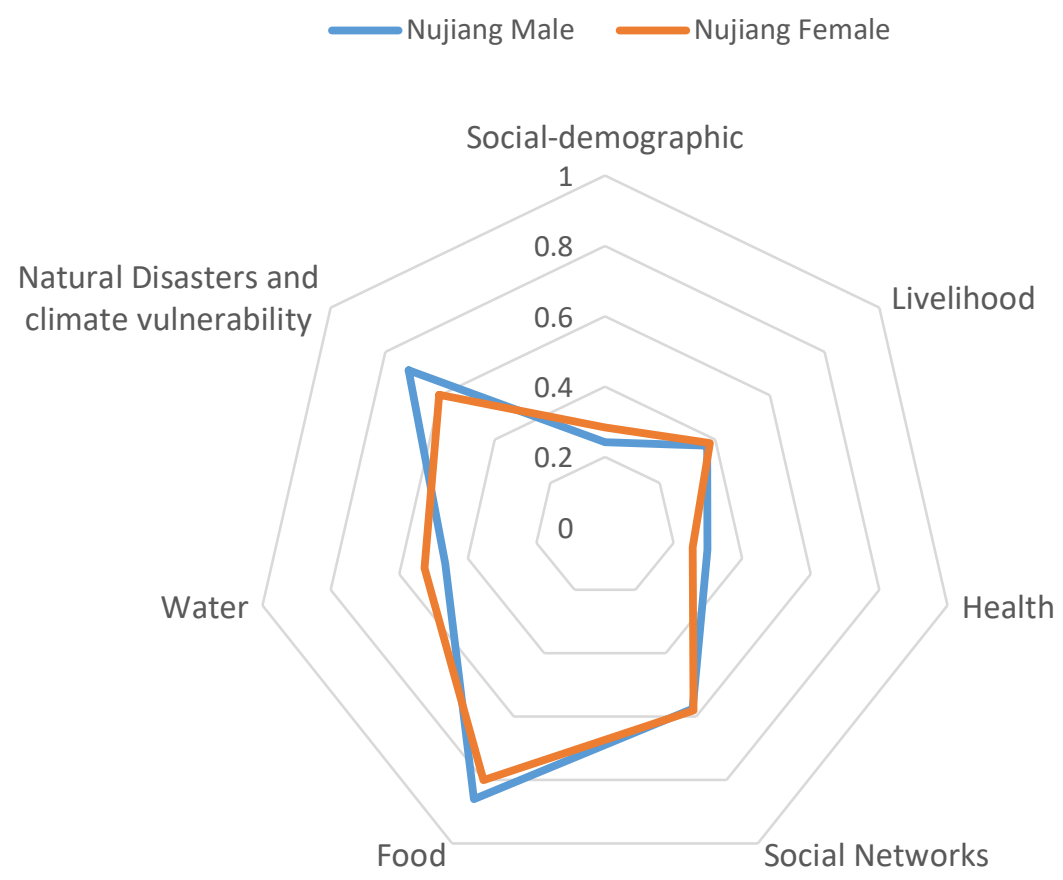

Figure 35 Livelihood vulnerability index in Nujiang

In Nujiang, female-headed households had significantly higher illiteracy rates, depended more on agriculture as their sole source of income, and experienced much less influence on the local community. They also reported that purchasing water was unaffordable, and experienced overall poorer water quality. Female-headed households experienced less exposure and sensitivity to climate change, and had an overall better LVI_IPCC score.

Male-headed households were more vulnerable as measured by the help-seeking channel index, had a higher frequency of illness, had less access to affordable health care and were more affected by natural disasters. Overall, male-headed households were slightly more vulnerable than female-headed households, but this difference was marginal. Male-headed households had more adaptive capacity. 
Table 26 LVI-IPCC value of each sub-components of gender across five prefectures

\begin{tabular}{|l|l|l|l|l|l|l|l|l|l|l|l|l|} 
& \multicolumn{2}{|c}{ Lincang } & \multicolumn{2}{c|}{ Baoshan } & \multicolumn{3}{c|}{ Dali } & \multicolumn{3}{c|}{ Diqing } & \multicolumn{2}{c|}{ Nujiang } \\
& Male & Female & Male & Female & Male & Female & Male & Female & Male & Female \\
\hline Adaptive capacity & 0.477 & 0.507 & 0.498 & 0.473 & 0.424 & 0.434 & 0.389 & 0.396 & 0.413 & 0.437 \\
\hline Exposure & 0.84 & 0.78 & 0.843 & 0.803 & 0.766 & 0.746 & 0.763 & 0.803 & 0.715 & 0.603 \\
\hline Sensitivity & 0.527 & 0.531 & 0.535 & 0.485 & 0.424 & 0.426 & 0.515 & 0.496 & 0.506 & 0.488 \\
\hline LVI_IPCC & 0.55 & 0.556 & 0.563 & 0.525 & 0.472 & 0.475 & 0.496 & 0.497 & 0.496 & 0.482 \\
\hline
\end{tabular}

Table 27 LVI-IPCC index of men and women

\begin{tabular}{|l|l|l|}
\hline & Male & Female \\
\hline Adaptive capacity & 0.361 & 0.348 \\
\hline Exposure & 0.77 & 0.73 \\
\hline Sensitivity & 0.33 & 0.365 \\
\hline LVI-IPCC & 0.135 & 0.139
\end{tabular}

\section{LVI-IPCC of gender in five prefectures}

The data suggests a very similar rate of vulnerability between all households of the same prefecture (see Appendix); however, Baoshan prefecture exhibited the most significant difference between male and female-headed households. Male-headed households in Baoshan were the most vulnerable and male-headed households in Dali were the least. Overall, women were generally slightly more vulnerable than men when vulnerability was analyzed through LVI and LVI-IPCC.

However, both food vulnerability and natural disasters and climate vulnerability displayed extremely high vulnerability scores across all of the households included in this study. One major reason for this widespread vulnerability is the general lack of climate change intervention in the rural communities of Yunnan Province. Therefore, this entire area exhibits a very high degree of climate change vulnerability. 


\section{Discussion}

\section{Changes in gender roles}

With rapid economic growth and urbanization, rural consumption has gradually increased, which has led to a rise in female migrant workers entering the work force and subsequently, an increase in women taking on non-traditional roles in the economy. However, gender differences still remain, male migrants are still more common than female migrants, and male migrants typically earn more than female migrants.

Although, the gender gap is closing in terms of economic participation, gender differences still exist in the sectors offering employment opportunities (off-farm jobs). Men are more likely to be employed in heavy industry, while women are more likely to be employed in the service sector and in labour-intensive manufacturing. Although, the survey data reveals a significant division of labour, and it is clear that women's roles have expanded more rapidly then men's roles in a modern economy. Women not only undertake traditional roles such as cleaning, cooking, and caring for the young and old, but are also expected to contribute to agricultural labour outside the home, such as compost making, weeding, harvesting, sowing, irrigating fields, fertilizing crops, and processing and storing the harvest. In general, agricultural labour has been recognized as a shared responsibility between men and women; however, LVI analysis revealed there was a lower rate of men participation reported in most agricultural responsibilities (listed above).

The rapidly expanding role of women has led to a higher burden of labour. This expansion of responsibility impacts women's adaptive capacity and overall vulnerability to climate change. In many cases, the evolving role of women has not led to an increase in decision-making power or community leadership positions. In all the study sites, men controlled most of the decision-making at the village level. Only 7\% of women throughout the prefectures were involved in local decision-making. Men had more numerous local networks and exhibited greater influence on local governance.

\section{Increasing impacts on agriculture, water, and health with regard to gender}

Climate change has had significant impacts on agriculture in Yunnan and especially on crop production, which has had both positive and negative consequences for community members. The impacts of climate change on farmers' livelihoods were mainly reflected in increased production inputs and reduced profits. Compared to female-headed households, male-headed households were engaged in a more diverse 
range of farming techniques, and were more likely to rely on agriculture as the main income source. Therefore, female-headed households seem more vulnerable to the impact of natural disasters because most only planted a single crop. However, femaleheaded households reported higher participation rates in off-farm labour, which could make their livelihoods less dependent on unpredictable weather and natural disasters. In Wang et al.'s (2016) study of gender and self-employment, it was found that women's participation in off-farm labour rose 40\% between 1980-2008. Participation of 21-40 year olds in off-farm work doubled during this same time period. The authors also found a general increase in the rate of self-employment. The Chinese national economy continued to grow between 2008-2016, and despite the slowdown due to the 2008 financial crisis, more opportunities for off-farm employment have been created (Morrison, 2015). Between 2005-2014 the average wage rose by 309\%, making off-farm employment increasingly more attractive (Morrison, 2016). This continued growth in opportunities for waged labour has fostered greater participation in off-farm employment, which has made the incomes of female-headed households slightly less vulnerable to changes in climate. This is especially important as more than $82 \%$ of the surveyed farmers reported a decrease in some type of agricultural production due to the recent drought.

LVI analysis revealed that vulnerability in Yunnan was particularly acute with regard to water. All households across Yunnan Province reported experiencing very high water-based vulnerability. Male headed-households in Lincang, Baoshan, Dali and Diqing experienced higher vulnerability in water affordability, while female-headed households experienced marginally higher vulnerability in water quality. Based on these two sub-indicators, male-headed households in Nujiang experienced the highest vulnerability overall and female-headed households in Baoshan were least vulnerable.

Health indicators similarly showed a high rate of vulnerability across all of the households surveyed. Of the three sub-indicators, affordability of treatment for serious illness or injury displayed the most significant variations and the highest overall vulnerability. Female-headed households in Lincang experienced the highest vulnerability in this sub-indicator, while female-headed households in Diqing experienced the least vulnerability. Considering the percentage of household health affected by natural disasters, female-headed households were significantly more vulnerable. Male-headed households reported significantly higher vulnerability in regard to frequency of illness.

In general, female-headed households were slightly more vulnerable in three major areas: Demographic factors, health, and access to water. Male-headed households 
were slightly more vulnerable in four major areas: Livelihoods, community networking, natural disasters, and climate change. Overall, gender did not significantly impact overall vulnerability, but based on the differences in sub-indicators, genderspecific interventions to improve climate change vulnerability could be used to most effectively target male or female-headed households for improvement. These groups should be targeted in different ways and will respond to community interventions differently; thus, gender experiences should be taken into account when determining community intervention. The information from this study could be used as a preliminary baseline to target areas where different communities have reported high levels of vulnerability, including: health, social networks, water and natural disasters and climate variability.

This study also detected significant gender differences in specific sub-indicators related to age, education, family structure, housing and rental prices, and labour income. Additionally, the LVI analysis found many significant differences between male and female-headed households agriculturally, economically, and in regard to participation in community decision-making. For example, male-headed households tended to have larger families, but a lower dependency ratio. There were more illiterate female-headed households than male-headed households. Male-headed households, on average, possessed more rooms than female-headed households; however, female household heads tended to believe that their properties would garner higher rents for their properties than did male household heads.

\section{High vulnerability in surveyed areas}

This study showed widespread vulnerability throughout the households in the surveyed areas. It also revealed that communities living in these areas have very little access to resources and support channels, as a result of which all households engage in similar coping strategies, most of which lacked innovative solutions to vulnerability. This could indicate that these communities have pre-existing difficulties in fulfilling their basic needs even without the added challenge of climate change vulnerability. As climate change advances with increasing speed, these factors are likely to combine to create ever-greater difficulties for vulnerable communities in the area. Although this study did not identify gender as a determining factor of vulnerability, the theoretical framework it used could be adapted by other studies which aim to include gender as an important factor in their analysis. The use of gender-disaggregated data, in particular, shows that women's vulnerability to climate change can be quantitatively and rigorously examined in the future. This study also demonstrates the need to parse gender-disaggregated data, by using the LVI framework, in order to 
determine the most effective gender-specific solutions to climate change vulnerability.

\section{Limitations}

The disadvantaged position of women within society often places female-headed households at a disadvantage (IFAD 1999; Rai 2002; Kabeer 2003). Female-headed households do not compete on a level playing field (Chant 2003) and it can give rise to economic disadvantage, compared to male headship, particularly in terms of income. However, it is essential to 'unpack' the category of 'female-headed households' within China to understand the finer details of its linkage to poverty, coping, and adaptation to climate change. LVI analysis was employed in this study, as a framework, that attempts to standardize extremely complex issues. The averages necessary to complete the LVI analysis often normalized the nuances found within vulnerability. This could have contributed to the relatively small-scale differences in reported vulnerabilities of male and female-headed households, despite the historical and well-documented marginalization of women in Chinese society. In addition, LVI analysis does not accurately capture the full diversity of adaptation at the household level. Most of the components and sub-components used in LVI analysis were reported at the household level; however, in many cases the social construction of marginalization occurs within a household. Therefore, an accurately depiction of marginalization requires data at the intra-household level as well. This is a challenge, but the collection and analysis of data is still worth the undertaking. Moreover, using household heads as the only unit of analysis in investigating differences in vulnerability between men and women has limited the scope of analysis. In addition, data collection without considering the sample size of male and female-headed households has contributed to a lack of strong findings in the results. For example, the unit used to examine the differences between men and women is the household head, but the number of male-headed households is four times higher than that of females. This should be a serious consideration in future studies.

In order to create a holistic understanding of vulnerability in Yunnan province it is important to combine this baseline information with qualitative evidence that encourages a strong sense of community participation. The LVI framework is most effectively used to understand how vulnerability is differentiated at the community level, in the future, it might be useful to combine this analysis with other more participatory activities such as resource mapping and focus-group discussions to provide a full understanding of climate change vulnerability. Further research is required to determine the vulnerabilities and strengths that female headship results in. 


\section{Differences among five prefectures}

Although there were strong commonalities among vulnerabilities in the surveyed prefectures, there were also important differences. Understanding these differences could help to identify appropriate measures to reduce vulnerability.

\section{Lincang}

In Lincang, female-headed households had a higher dependency ratio, a higher illiteracy rate, and planted less diverse crops than their male-headed counterparts. Female-headed households also experienced a higher frequency of serious illness, poorer water quality and had less access to affordable healthcare. Female-headed households also reported more difficulty accessing loans and less influence on local community governance. Male-headed households reported that purchasing water was unaffordable, and also were less likely to say that they had access to channels which might help them get assistance.

Based on these factors, the LVI analysis indicated that female-headed households were marginally more vulnerable than male-headed households in this area.

\section{Baoshan}

Over half of respondents indicated that over the past 20 years they had observed warmer temperatures during the cold season. No significant difference was observed between male and female respondents concerning changes in precipitation. In Baoshan, female-headed households exhibited a higher financial burden despite lower dependence ratios. In addition, female-headed households experienced less access to affordable healthcare, poorer water quality and less access to help-seeking channels. Female-headed households typically relied more on salary wages to support the household. Male-headed households were more likely to rely on agriculture and livestock for income, displayed higher illiteracy rates and believed that purchasing water was unaffordable.

Generally, male-headed households displayed a higher level of overall vulnerability through the LVI analysis.

\section{Dali}

In Dali, female-headed households reported having more access to affordable healthcare and having better influence over local decisions and purchasing water, which indicates that they were more able to adapt to illness. Male-headed households 
reported a higher dependency ratio and relied on agriculture as their sole source of income.

According to the analysis, both types of households had similar level of livelihoods vulnerability.

\section{Diqing}

In Diqing, female-headed households were more likely to depend on agriculture as their sole source of income, had less access to help-seeking channels and were more likely to be affected seriously by natural disasters. Male-headed households tended to have higher dependency ratios, were more vulnerable in terms of the Average Agricultural Livelihood Diversification Index, and had less influence on the local community. Male-headed households also reported that purchasing water was unaffordable and experienced poorer water quality.

According to the analysis, both types of households had similar level of livelihoods vulnerability.

\section{Nujiang}

Nujiang's respondents received at least $12 \%$ more government benefits than all the other prefectures. Nujiang had the lowest dependency ratios. Family sickness and impact of rodents on food resources were ranked as the top two shocks.

In Nujiang, female-headed households reported higher illiteracy rates, depended on agriculture as their sole source of income, and reported having much less influence on local community governance. Male-headed households were more vulnerable as measured by the help-seeking channel index, had a higher frequency of illness, experienced less access to affordable health care and were more affected by natural disasters.

According to the analysis, male-headed households were slightly more vulnerable than female-headed households, but this difference was marginal.

\section{Conclusion and Recommendations}

Awareness of climate change among rural men and women is still low, and our results showed a preference for short-term coping measures. In order to raise awareness and promote long-term solutions, it is important for governments and scientists to share information on climate change and its impacts (Pradhan et al. 2012).

As the impact of climate change on women's lives varies between regions and cultures, the design and planning of climate change adaptation policies needs to focus more closely on local contexts. Climate change can exacerbate pre-existing 
inequalities and further marginalize women and other underrepresented groups. The ability of people to cope and adapt to climate change depends on their status, behaviour, relationships and power (Pradhan et al. 2012). Based on the results of this study, communities in Yunnan exhibit gender-specific differences in consumption patterns, lifestyles, access to and control of resources, decision-making and power relations, and vulnerability to climate change. In the future, women's gendered knowledge of natural resources and their common responsibilities in households and communities should be seen as strengths within the community, and leveraging these strengths will be crucial for successful long-term climate adaptation (Pradhan et al. 2012). Overall, female-headed households are more vulnerable than male-headed households in terms of climate change, particularly in regard to demographic factors, health and access to water.

Many previous studies have documented the typically poor water resources of rural western China; however, a study in 2015 provided a very detailed framework as to how to improve access to water and water quality (Yu, Geng, Heck \& Xue 2015). This framework suggested that more international funding be allocated to research and development in order to find better technical solutions for removing pollution from large water sources (Yu, Geng, Heck \& Xue 2015). This should include on-site fieldwork aimed at adapting national policies to local contexts.

This study has found that female-headed household members are more vulnerable to illness. Women in rural areas may struggle more to access affordable, good quality healthcare than men due to their roles in reproduction and birth control. However, all rural residents are vulnerable to health-related shocks because of the limited resources, inadequate education, and limited supervision of services that are associated with rural China (Lingnan University, 2011). Rural residents are more likely to be disease carriers and victims of communicable disease. Although China's New Rural Cooperative Medical Insurance has almost $100 \%$ coverage of rural areas, this only translates to an annual increase of $120 \mathrm{RMB}$ of medical care per capita (Lingnan University, 2011). Although increasing medical infrastructure and expertise in rural areas would be the most effective way to improve access to healthcare, this is a longterm goal that may take several decades to become a reality. In many countries, including the United States, mobile health (mhealth) has become a useful tool for monitoring long-term illnesses and care ( $\mathrm{Ni}, \mathrm{Wu}$, Sample \& Shaw 2015). This innovative health technology could be an effective method of overcoming rural gender biases and providing affordable care to rural areas while increasing access to healthcare for women. 
In order to target these areas of vulnerability, rural areas need to be provided with greater access to information by strengthening local agricultural disaster warning systems. This can only be done by investing in village-level detection and monitoring systems (Samarajiva et al. 2005). Effective warning systems require institutional planning and the capacity to convert hazard detection data into explicit and reliable alerts and warnings that are widely accessible through channels such as cell broadcasts, local news and community institutions. (Samarajiva et al. 2005).

However, regardless of the methods chosen, adaptation approaches should recognize the specific needs of women and marginalized groups by considering the challenges faced by these groups in receiving information. Dissemination techniques should take into account specific vulnerabilities concerning illiteracy, educational background and access to information, and provide easily understood, actionable data for women. In conjunction with investing in information dissemination, it is also necessary to create fora where the voices of women and disadvantaged groups are included in discussions about climate change impacts. This would allow women to advocate for participation and equality in the leadership roles of local decision-making bodies, which would contribute to building an effective community alliance for climate change adaptation.

Future research in the target areas is needed in order to thoroughly understand longterm and short-term climate risks. Based on this study, adaptation strategies should integrate health, water, natural disaster risk and climate adaptation resources into planning frameworks while establishing flexible and innovative support channels. This can be accomplished by encouraging public participation, including the participation of non-governmental organizations, research institutions, government agencies and all relevant stakeholders in climate change decision-making, with a special awareness of gender-related inequalities.

This study has identified some of the interventions and support mechanisms that are needed in Yunnan province. It has also outlined some of the ways in which different segments of the population can be engaged in order to build adaptive capacities in vulnerable groups. For instance, many community members are aware of weather pattern changes, but lack the understanding that these changes are a part of a larger shift in Yunnan's climate. Without this knowledge, many households have opted for short-term solutions that do not adequately prepare their families and communities for the future. The baseline data collected through this analysis could be used by research institutes, government agencies, NGOs and others to target this knowledge gap about climate change. The disaggregated data provided by our survey could help mitigate the risk of such efforts unintentionally marginalizing certain segments of the population, such as women and poor people, or inequitably distributing resources. 
The LVI analysis presented in this study allows for a thorough review of the local context, meaning that anyone designing policy interventions or projects can better predict which households and what percentage of overall households will be reached through a specific intervention. By including gender-disaggregated data, it also draws attention to the importance of considering gender differences in framing responses and interventions. This understanding of local context is an important step in ensuring that interventions are successful and cost effective.

Specifically, interventions in the management of water, health, natural disasters, and climate variability are needed in order to make this region more adaptable. Focusing on meeting the basic needs of the community in the health and water sectors could both make households less vulnerable and help provide the necessary time, energy, and capital needed to develop innovative adaption solutions. Without lowering the day-to-day vulnerability of these households, effective adaptations to climate change are less likely to be developed and widely adapted. The results of this analysis have provided a first step towards the greater goal of climate change adaptability, which when shared with appropriate actors can inform effective and timely interventions.

At present, climate change adaptation policies in China focus more on natural ecosystems than socio-economic issues (Peng et al., 2015), and there are no genderrelated considerations in the National Strategy for Climate Change Adaptation issued in 2013 and 2015. However, the importance of gender as a key variable which mediates vulnerability to climate change and adaptive capacity is increasingly recognized (Nelson and Stathers 2009; Olsson et al 2014; Paolisso et al 2002). Femaleheaded households are often more dependent on natural resources and access to non-timber forest products (Liu \& Yao, 2012; Wu, 2008) than male-headed households. This study found that women were slightly more vulnerable to the impact of climate disasters; in addition, women are often less visible when it comes to the distribution of disaster relief.

The results of this study support the conclusion that women are largely disenfranchised from local decision-making, which limits their exposure to climate change-related knowledge, strategy and early warning systems. The limited participation of women in decision-making also means that their traditional knowledge, experience, needs and concerns are likely to be ignored or underestimated. Various structural factors also restrict the ability of women to cope with climate change: for example, women often receive fewer years of education than men, which may impact agricultural productivity and limit the technology that women can access in order to adapt. Therefore, adaptation strategies should concentrate on 
providing rural communities, and rural women in particular, with improved access to education and technologies which can aid adaptation and reduce vulnerability. 


\section{References}

Byrne, B. and Baden, S. 1995. Gender emergencies and humanitarian assistance. BRIDGE Report No 35, IDS, Sussex.

Carr, E.R. 2008. Between structure and agency: Livelihoods and adaptation in Ghana's central region. Global Environmental Change 18(4): 689-99.

Cartier Charitable Foundation. 2014. Preparing for natural disasters in Western China. Cartier Charitable Foundation

http://www.cartiercharitablefoundation.org/encommitment/programs/planningand-preparing-for-natural-disasters-in-western-china. Accessed on 16 October 2017.

Chant, S. 2003. New contributions to the analysis of poverty: methodological and conceptual challenges to understanding poverty from a gender perspective. Women and Development Unit, Santiago, Chile.

Chaskin, R. 2001. Building community capacity: a definitional framework and case studies from a comprehensive community initiative. Urban Affairs Review 36(3): 291323. doi:10.1177/10780870122184876

Chen W, Cutter SL, Emrich CT, Shi P. 2013. Measuring social vulnerability to natural hazards in the Yangtze River delta region, China. International Journal for Disaster Risk Science 4(4): 169-81.

China Internet Information Center. 2015. Yunnan province http://www.china.org.cn/e-xibu/2Jl/3Jl/yunnan/yunnan-ban.htm. Accessed on 16 October 2017.

China Internet Watch. 2015. China Internet statistics whitepaper. https://www.chinainternetwatch.com/whitepaper/china-internet-statistics. Accessed on 16 October 2017.

Dali, Yunnan Province. 2016. China Today. http://www.chinatoday.com/city/dali.htm. Accessed on 16 October 2017.

Dankelman, I. 2002. Climate Change: Learning from Gender Analysis and Women's Experiences of Organising forSustainable Development. Gender and Development 10(2): 21-9.

De Brauw, A., Li, Q., Liu, C., Rozelle, S., \& Zhang, L. 2008. Feminization of agriculture in China? Myths surrounding women's participation in farming. The China Quarterly 194: 327-48. 
Ding, Y.H., Ren, G.Y., Shi, G.Y., Gong, P., Zheng, X.H.,...et al. 2007. China's National Assessment Report on Climate Change (I): Climate change in China and the future trend. Advance in Climate Change Research. 3 (Suppl.): 1-5.

Feng, A. 2006. The status and rights of women in China during the Ming and Qing periods: An examination of Ming-Qing contracts and litigation archives. Japanese Society for the Promotion of Science. https://www.jsps.go.jp/english/eronpaku/2006/01 Fen.pdf.

Gerlitz, J-Y., Benerjee, S., Hoermann, B., Hunzai, K., Macchi, M., \& Tuladhar, S. 2014. Poverty and Vulnerability Assessment - A survey instrument for the Hindu Kush Himalayas. International Centre for Integrated Mountain Development.

Hahn, M., Riederer, A., \& Foster, S. 2009. The livelihood vulnerability index: A pragmatic approach to assessing risks from climate variability and change-A case study in Mozambique. Global Environmental Change.

doi:10.1016/j.gloenvcha.2008.11.002

Holmes, R., \& Jones, N. 2009. Gender inequality, risk and vulnerability in the rural economy: Re-focusing the public works agenda to take account of economic and social risks. ESA Working Paper No. 11-13.

http://www.fao.org/docrep/013/am318e/am318e00.pdf.

Hunter, L. M., \& David, E. 2011. Climate change and migration: considering gender dimensions. Climate Change and Migration: 306-30.

Hu, X., \& Zimmer, Y. 2013. China's corn production - Where to establish agri benchmark farms in corn. http://www.agribenchmark.org/fileadmin/Dateiablage/BCash-Crop/Working-Paper/cc-1303-China-XH-YZ.pdf.

IFAD [International Fund for Agricultural Development]. 1999. Rural poverty assessment: Asia and the Pacific.

www.ifad.org/gender/learning/role/workload/in generation.

Jirong, S. 2006. The family status of Chinese women-past and present. http://digitalcommons.uri.edu/cgi/viewcontent.cgi?article=1003\&context=sadc.

Kabeer, N. 2003. Gender Mainstreaming in Poverty Eradication and the Millennium Development Goals: A Handbook for Policy-makers and Other Stakeholders. London: Commonwealth Secretariat.

Liu, B. 2015. The practice of International Women's participation in politics and its influence on Chinese women's participation in politics Journal of China National School of Administration 2:48-52. 
Liu, $X \&$ Yao D. 2012. An analysis of the feminization of agriculture and its formation mechanism. Journal of Hunan University of Science \& Technology 15(4): 99-102.

Lu, C. 2010. Who is poor in China? A comparison of alternative approaches to poverty assessment in Rural Yunnan. The Jounrnal of Peasant Studies 37(2). doi:10.1080/03066151003595242

Morrison, W. M. 2015. China's economic rise: History, trends, challenges, and implications for the United States. Congressional Research Service (Issue Brief No. 7 5700). https://www.fas.org/sgp/crs/row/RL33534.pdf.

Mu, R., \& van de Walle, D. 2011. Left behind to farm? Women's labour re-allocation in rural China. Labour Economics (18): S83-97.

NDRC [National Development and Reform Commission]. 2013. China's Policies and Actions for Addressing Climate Change.

http://en.ndrc.gov.cn/newsrelease/201311/P020131108611533042884.pdf.

Accessed on October 16, 2017.

NDRC [National Development and Reform Commission]. 2015. China's Policies and Actions on Climate Change.

http://en.ccchina.gov.cn/archiver/ccchinaen/UpFile/Files/Default/20151120095849 657206.pdf. Accessed on October 16, 2017.

Nelson, G. C., Rosegrant, M. W., Koo, J., Robertson, R., Sulser, T., Zhu, T., . . Lee, D. 2009. Climate change: Impact on agriculture and the cost of adaptation.

http://www.saiplatform.org/uploads/Library/IFPRIONCC.pdf.

Nelson, V. and T. Stathers. 2009. Resilience, power, culture, and climate: A case study from semi-arid Tanzania, and new research directions. Gender and Development 17 (1): 81-94.

Nelson, V., Meadows, K., Cannon, T., Morton, J., \& Martin, A. 2002. Uncertain predictions, invisible impacts, and the need to mainstream gender in climate change adaptations. Gender \& Development 10(2): 51-59.

Ni, Z., Wu, B., Samples, C., \& Shaw, R. 2014. Mobile technology for health care in rural China. International Journal of Nursing Sciences 1(3): 323-4.

Olsson L, Opondo M, Tschakert P, Agrawal A, Eriksen SH, Ma S, Perch LN, Zakieldeen SA. 2014. Livelihoods and poverty. In: Field CB, Barros VR, Dokken DJ, Mach KJ, Mastrandrea MD, Bilir TE, ...White LL, editors. Climate Change 2014: Impacts, Adaptation, and Vulnerability. Part A: Global and Sectoral Aspects. Contribution of Working Group II to the Fifth Assessment Report of the Intergovernmental Panel on 
Climate Change. Cambridge University Press. Cambridge, United Kingdom and New York, NY, USA, 793-832.

Omolo, N.A. 2011. Gender and climate change-induced conflict in pastoral communities: Case study of Turkana in northwestern Kenya. African Journal on Conflict Resolution 10(2). doi: 10.4314/ajcr.v10i2.63312

Paolisso, M., A. Ritchie, and A. Ramirez. 2002. The significance of the gender division of labour in assessing disaster impacts: A case study of Hurricane Mitch and hillside farmers in Honduras. International Journal of Mass Emergencies and Disasters 20 (2): 171-95.

Pearson, V., Phillips, M., He, F., \& Ji, H. 2002. Attempted suicide among young rural women in The People's Republic of China: Possibilities for prevention. Suicide and Life-Threating Behavior 32(4).

Pradhan, N. S., Khadgi, V. R., Schipper, L., Kaur, N. and Geoghegan, T. 2012. Role of Policy and Institutions in Local Adaptation to Climate Change: Case studies on responses to too much and too little water in the Hindu Kush Himalayas. ICIMOD, Kathmandu.

Quisumbing, A.R., N. Kumar, and J. Behrman. 2011. Do shocks affect men's and women's assets differently? A review of literature and new evidence from Bangladesh and Uganda. IFPRI Discussion Paper 01113. Washington, D.C.: International Food Policy Research Institute.

Roncoli, C, K. Ingram, and P. Kirshen. 2001. The costs and risks of coping with drought: Livelihood impacts and farmers' responses in Burkina Faso. Climate Research 19 (2): 119-32.

Rai, S. 2002. Gender and the Political Economy of Development. Cambridge: Polity. Samarajiva, R. 2005. Mobilizing information and communications technologies for effective disaster warning: Lessons from the 2004 tsunami. New Media and Society 7(6): 731-47. doi: 10.1177/1461444805058159

Sapkota P, Keenan RJ, Paschen JA, Ojha HR. 2016. Social production of vulnerability to climate change in the rural middle hills of Nepal. Journal of Rural Studies (48): 5364.

Statista. 2016. Mobile phone penetration in China as share of the population from 2013 to 2019*. The stastistics portal.

http://www.statista.com/statistics/233295/forecast-of-mobile-phone-userpenetration-in-china/. Accessed on October 16, 2017. 
Statista. 2016. Number of mobile cell phone subscribers in China from June 2015 to June 2016 (in millions). The stastistics portal.

http://www.statista.com/statistics/278204/china-mobile-users-by-month/. Accessed on October 16, 2017.

Statistical Bureau of Yunnan Province (SBYP). 2016. Yunnan Statistical Yearbook (Vol. 31). China Statistics Press.

Statistical Bureau of Yunnan Province (SBYP). 2017. Yunnan Statistical Yearbook (Vol. 32). China Statistics Press.

The Nature Conservancy. 2016. China: Northern Gaoligong mountain range. http://www.nature.org/ourinitiatives/regions/asiaandthepacific/china/placesweprot ect/china-northern-gaoligong-mountain-range.xml. Accessed on May 9, 2017.

van Wesenbeeck C, Sonneveld B, Voortman R. 2016. Localization and characterization of populations vulnerable to climate change: Two case studies in Sub-Saharan Africa. Applied Geography (66): 81-91.

doi:10.1016/j.apgeog.2015.11.001

Wang, X., Han, L., Huang, J., Zhang, L., \& Rozelle, S. 2016. Gender and selfemployment: Evidence from rural China. Rural Education Action Program 289.

$\mathrm{Wu}, \mathrm{H}$; \& Zhang S. 2008. Literature Review on Agricultural Feminization. Research in Agriculture Development 2: 9-11.

Xie, Y. 2013. Gender and family in contemporary China: Population Studies Center Research Report at the University of Michigan.

http://www.psc.isr.umich.edu/pubs/pdf/rr13-808.pdf.

Xu S, Tian N. 2015. An empirical study on gender differences in the income of migration people- Based on the data of Jiangsu, Zhejiang and Shanghai. Guizhou Social Sciences 305(5). doi:10.13713/j.cnki.cssci.2015.05.006

Yu, X., Geng, Y., Heck, P., \& Xue, B. 2015. A review of China's rural water management. Sustainability (7): 5773-92. doi:10.3390/su7055773

Zhang, K. H., \& Song, S. 2003. Rural-urban migration and urbanization in China:

Evidence from time-series and cross-section analyses. China Economic Review 14(4): 386-400.

Zomer, R.J., Trabucco, A., Wang, M. \& Xu, J.C. 2016. Projected Climate Change Impact on Hydrology, Bioclimatic Conditions, and Terrestrial Ecosystems in the Asian Highlands. ICRAF Working Paper 222. World Agroforestry Centre East and Central Asia: Kunming. 


\section{Working Paper Series}

240. The national agroforestry policy of India: experiential learning in development and delivery phases. http://dx.doi.org/10.5716/WP16143.PDF

241. Agroforestry and forestry in Sulawesi series: Livelihood strategies and land-use system dynamics in Gorontalo. http://dx.doi.org/10.5716/WP16157.PDF

242. Seri Agroforestri dan Kehutanan di Sulawesi: Strategi mata pencaharian dan dinamika system penggunaan lahan di Gorontalo.

http://dx.doi.org/10.5716/WP16158.PDF

243. Ruang, Gender dan Kualitas Hidup Manusia: Sebuah studi Gender pada komunitas perantau dan pengelola kebun di Jawa Barat.

http://dx.doi.org/10.5716/WP16159.PDF

244. Gendered knowledge and perception in managing grassland areas in East Sumba, Indonesia. http://dx.doi.org/10.5716/WP16160.PDF

245. Pengetahuan dan persepsi masyarakat pengelola padang aavana, Sebuah Kajian Gender di Sumba Timur. http://dx.doi.org/10.5716/WP16161.PDF

246. Dinamika Pengambilan Keputusan pada komunitas perantau dan pengelola kebun di Jawa Barat. http://dx.doi.org/10.5716/WP16162.PDF

247. Gaharu (eaglewood) domestication: biotechnology, markets and agroforestry options. http://dx.doi.org/10.5716/WP16163.PDF

248. Marine habitats of the Lamu-Kiunga coast: an assessment of biodiversity value, threats and opportunities. http://dx.doi.org/10.5716/WP16167.PDF

249. Assessment of the biodiversity in terrestrial landscapes of the Witu protected area and surroundings, Lamu County, Kenya.

http://dx.doi.org/10.5716/WP16172.PDF

250. An ecosystem services perspective on benefits that people derive from biodiversity of Coastal forests in Lamu County, Kenya http://dx.doi.org/10.5716/WP16173.PDF 
251. Assessment of the biodiversity in terrestrial and marine landscapes of the proposed Laga Badana National Park and surrounding areas, Jubaland, Somalia. http://dx.doi.org/10.5716/WP16174.PDF

\section{7}

252. Preferensi Petani terhadap Topik Penyuluhan dan Penyebaran Informasi Agroforestri di Indonesia http://dx.doi.org/10.5716/WP16181.PDF

253. Seri Agroforestri dan Kehutanan di Sulawesi: Keanekaragaman hayati jenis pohon pada hutan rakyat agroforestri di DAS Balangtieng, Sulawesi Selatan http://dx.doi.org/10.5716/WP16182.PDF

254. Potensi dan Tantangan dalam Pengembangan Skema Ko-Investasi Jasa Lingkungan di Kabupaten Buol, Indonesia. http://dx.doi.org/10.5716/WP17008.PDF

255. Keragaman Jenis Pohon dan Pemanfaatannya oleh Masyarakat di Kabupaten Buol, Indonesia. http://dx.doi.org/10.5716/WP17009.PDF

256. Kerentanan dan preferensi sistem pertanian petani di Kabupaten Buol, Indonesia http://dx.doi.org/10.5716/WP17010.PDF

257. Dinamika Perubahan Penggunaan/Tutupan Lahan Serta Cadangan Karbon di Kabupaten Buol, Indonesia. http://dx.doi.org/10.5716/WP17011.PDF

258. The effectiveness of the volunteer farmer trainer approach vis-à-vis other information sources in dissemination of livestock feed technologies in Uganda. http://dx.doi.org/10.5716/WP17104.PDF

259. Agroforestry and forestry in Sulawesi series: Impact of agricultural-extension booklets on community livelihoods in South and Southeast Sulawesi.

http://dx.doi.org/10.5716/WP17125.PDF

260. Petani Menjadi Penyuluh, Mungkinkah? Sebuah Pendekatan Penyuluhan dari Petani ke Petani di Kabupaten Sumb Timur. http://dx.doi.org/10.5716/WP17145.PDF

261. Dampak Perubahan Tutupan Lahan terhadap Kondisi Hidrologi di Das Buol, Kabupaten Buol, Sulawesi Tengah: Simulasi dengan Model Genriver http://dx.doi.org/10.5716/WP17146.PDF 
262. Analisis Tapak Mata Air Umbulan, Pasuruan, Jawa Timur. Kajian elemen biofisik dan persepsi masyarakat. http://dx.doi.org/10.5716/WP17147.PDF

263. Planned comparisons demystified. http://dx.doi.org/10.5716/WP17354.PDF

264. Soil health decision support for NERC digital soil platforms: A survey report http://dx.doi.org/10.5716/WP17355.PDF

265. Seri Pembangunan Ekonomi Pedesaan Indonesia: Menanam di bukit gundul: Pengetahuan masyarakat lokal dalam upaya restorasi lahan di Sumba

Timur. http://dx.doi.org/10.5716/WP17356.PDF

266. Tree diversity and carbon stock in three districts of Kutai Timur, Pasir and Berau, East Kalimantan http://dx.doi.org/10.5716/WP17357.PDF

267. Tree Diversity and Carbon Stock in Various Land Use Systems of Banyuasin and Musi Banyuasin Districts, South Sumatera http://dx.doi.org/10.5716/WP17358.PDF

268. Tree diversity and carbon stock in various land cover systems of Jayapura, Jayawijaya and Merauke Districts, Papua

Province http://dx.doi.org/10.5716/WP17359.PDF

269. Modelling tree production based on farmers' knowledge: case for kapok (Ceiba pentandra) and candlenut (Aleurites mollucana) under various agroforestry scenarios. http://dx.doi.org/10.5716/WP17361.PDF

270. The Impact of Land Cover and Climate Change on Present and Future Watershed Condition. Study case: Tugasan, Alanib and Kulasihan Sub-watershed of Manupali Watershed, Lantapan, Bukidnon, Philippines.

http://dx.doi.org/10.5716/WP17362.PDF

271. Tree Diversity and Above-ground Carbon Stock estimation in Various Land use Systems in Banjarnegara, Banyumas and Purbalingga, Central Java.

http://dx.doi.org/10.5716/WP17363.PDF 
272. Agroforestry and Forestry in Sulawesi series: Landscape Management Strategies in Sulawesi: Review of Intervention Options.

\section{http://dx.doi.org/10.5716/WP17364.PDF}

273. Household Food-Security and Nutritional Status of Women and Children in Buol Regency, Central Sulawesi, Indonesia. http://dx.doi.org/10.5716/WP17365.PDF

274. Palm oil expansion in tropical forest margins or sustainability of production? Focal issues of regulations and private standards.

http://dx.doi.org/10.5716/WP17366.PDF

\section{$\underline{2018}$}

275. Decision analysis methods guide: Agricultural policy for nutrition http://dx.doi.org/10.5716/WP18001.PDF

276. Supporting human nutrition in Africa through the integration of new and orphan crops into food systems: Placing the work of the African Orphan Crops Consortium in context. http://dx.doi.org/10.5716/WP18003.PDF

277. Seri Pembangunan Ekonomi Pedesaan Indonesia. Pilihan Manajemen Budidaya Kacang Tanah sebagai Upaya untuk Memperbaiki Penghidupan Masyarakat Haharu. http://dx.doi.org/10.5716/WP18004.PDF

278. Estudio de línea de base CCAFS a nivel de hogar en Nicaragua y Costa Rica Fase de diagnóstico del estudio: "Contribución de la diversidad arbórea a los medios de vida para la adaptación y la mitigación al cambio climático http://dx.doi.org/10.5716/WP18005.PDF

279. Understanding tree cover transition, drivers and stakeholder perspectives for effective landscape governance. A case study in Na Nhan commune, Dien Bien province, Vietnam. http://dx.doi.org/10.5716/WP18006.PDF

280. El Sistema "Quesungual": Agroforestería y manejo de suelos para la producción de maíz y frijol en laderas. http://dx.doi.org/10.5716/WP18007.PDF

281: Probabilistic Decision Modelling to Determine Impacts on Natural Resource Management and Livelihood Resilience in Marsabit County, Kenya. http://dx.doi.org/10.5716/WP18008.PDF 
282. Shifting discourse, shifting power: how is climate change mitigation and justice negotiated in Indonesia? http://dx.doi.org/10.5716/WP18009.PDF

283. Result of Land Use Planning and Land Administration (LULA) Implementation in South Sumatra, East Kalimantan, Central Java and Papua http://dx.doi.org/10.5716/WP18010.PDF

284. Farmers' preferences for training topics and dissemination of agroforestry information in Indonesia. http://dx.doi.org/10.5716/WP18015.PDF

285. CSA-Diagnostic (CSA-Dx): A primer for investigating the 'climate-smartness' of ag technologies http://dx.doi.org/10.5716/WP18020.PDF

286. An analysis of the vulnerability of poor communities in Yunnan Province, China http://dx.doi.org/10.5716/WP18021.PDF

287. Gendered space and quality of life: gender study of out-migration and smallholding agroforestry communities in West Java Province, Indonesia. http://dx.doi.org/10.5716/WP18024.PDF

288: Evaluation of UTZ certification coffee businesses in Guatemala, Honduras and Nicaragua. http://dx.doi.org/10.5716/WP18028.PDF

289. Agroforestry species of Peru: annotated list and contribution to prioritization for genetic conservation. http://dx.doi.org/10.5716/WP18029.PDF

290. Indonesia Rural Economic Development Series.Growing plants on a barren hill: local knowledge as part of land restoration in Sumba Timur, Indonesia. http://dx.doi.org/10.5716/WP18030.PDF

291. Assessing the Downstream Socioeconomic Impacts of Agroforestry in Kenya http://dx.doi.org/10.5716/WP18033.PDF

\section{$\underline{2019}$}

292: Los árboles fuera del bosque en la NAMA forestal de Colombia. Elementos conceptuales para su contabilización. http://dx.doi.org/10.5716/WP19002.PDF 
The World Agroforestry (ICRAF) is a centre of scientific excellence that harnesses the benefits of trees for people and the environment. Leveraging the world's largest repository of agroforestry science and information, we develop knowledge practices, from farmers' fields to the global sphere, to ensure food security and environmental sustainability.

ICRAF is the only institution that does globally significant agroforestry research in and for all of the developing tropics. Knowledge produced by ICRAF enables governments, development agencies and farmers to utilize the power of trees to make farming and livelihoods more environmentally, socially and economically sustainable at multiple scales.

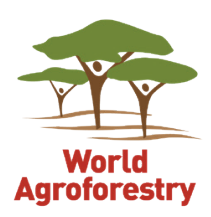

United Nations Avenue, Gigiri • PO Box 30677 • Nairobi, $00100 \cdot$ Kenya Telephone: +254207224000 or via USA +1 6508336645 Fax: +254207224001 or via USA +1 6508336646 Email: worldagroforestry@cgiar.org•www.worldagroforestry.org 